\title{
GLOBAL EMPLOYMENT TRENDS FOR YOUTH
}


Copyright (C) International Labour Organization 2006

Publications of the International Labour Office enjoy copyright under Protocol 2 of the Universal Copyright Convention. Nevertheless, short excerpts from them may be reproduced without authorization, on condition that the source is indicated. For rights of reproduction or translation, application should be made to the ILO Publications (Rights and Permissions), International Labour Office, CH-1211 Geneva 22, Switzerland. The International Labour Office welcomes such applications.

ISBN 92-2-118627-X and 978-92-2-118627-4 (print)

ISBN 92-2-118628-8 and 978-92-2-118628-1 (web pdf)

First published 2006

The designations employed in ILO publications, which are in conformity with United Nations practice, and the presentation of material therein do not imply the expression of any opinion whatsoever on the part of the International Labour Office concerning the legal status of any country, area or territory or of its authorities, or concerning the delimitation of its frontiers.

The responsibility for opinions expressed in signed articles, studies and other contributions rests solely with their authors, and publication does not constitute an endorsement by the International Labour Office of the opinions expressed in them.

Reference to names of firms and commercial products and processes does not imply their endorsement by the International Labour Office, and any failure to mention a particular firm, commercial product or process is not a sign of disapproval.

ILO publications can be obtained through major booksellers or ILO local offices in many countries, or direct from ILO Publications, International Labour Office, CH-1211 Geneva 22, Switzerland. Catalogues or lists of new publications are available free of charge from the above address, or by email: pubvente@ilo.org

Visit our website: www.ilo.org/publns 


\section{Foreword}

The world is facing a growing youth employment crisis. Both developing and developed economies are faced with the challenge of creating decent and sustainable jobs for the large cohort of young women and men entering the labour market every year. The issue features prominently on the international development agenda. Youth employment is a major focus of the Millennium Development Goals (MDGs) and was reaffirmed by the Ministers and Heads of Delegations participating in the High-Level Segment of the Substantive 2006 Session of the Economic and Social Council (ECOSOC) who committed themselves to "develop[ing] and implement[ing] strategies that give youth everywhere a real and equal opportunity to find full and productive employment and decent work". 1

Recognizing that a failure to successfully integrate young people into the labour market has broader consequences for the future prosperity and development of countries, in June 2005 ILO constituents adopted a resolution on youth employment which spelled out an "ILO plan of action to promote pathways to decent work". ${ }^{2}$ One element is to expand knowledge of the nature and dimensions of youth employment, unemployment and underemployment. The ILO Global Employment Trends for Youth aims to do just that.

This report adds to growing evidence of a global situation in which young people face increasing difficulties when entering the labour force. One of the principal findings is that a global deficit of decent work opportunities has resulted in a situation in which one out of every three youth in the world is either seeking but unable to find work, has given up the job search entirely or is working but still living below the US\$2 a day poverty line. Without the right foothold from which to start out right in the labour market, young people are less able to make choices that will improve their own job prospects and those of their future dependents. This, in turn, perpetuates the cycle of insufficient education, low-productivity employment and working poverty from one generation to the next. The report, therefore, adds urgency to the UN call for development of strategies aimed to give young people a chance to make the most of their productive potential through decent employment.

This report provides empirical research as well as quantitative assessments of the realities of youth labour markets to build an analytical starting block from which countries can identify the main challenges facing youth for the process of designing the policies most suited to their particular situations. At the same time, the data and analyses in the Global Employment Trends for Youth will strengthen the capacity of the ILO's programme on youth employment to provide assistance to countries in developing coherent and coordinated interventions on youth employment that are based on analytical reviews of labour market information.

For further expansion of the youth employment knowledge base, the need is not one of developing new indicators, but rather finding a way to make use of the indicators that already exist (labour force participation rates, employment ratios, unemployment rates, employment by status and by sector, long-term unemployment, underemployment, hours of work and poverty). The challenge, however, is that, as of now, many of the labour market indicators listed here cannot be applied to youth because most countries do not provide the data disaggregated by age. The ILO is intensifying its efforts to gather the data by age groups. This will help to improve the accuracy and reliability of labour market analyses within a life-cycle perspective.

\footnotetext{
${ }^{1}$ ECOSOC High-level Segment: Ministerial Declaration, 5 July 2006, E/2006/L.8.

${ }^{2}$ ILO: "Conclusions on promoting pathways for decent work for youth”, paragraph 5, ILC, 93rd Session (Geneva, 2005); www.ilo.org/public/english/standards/relm/ilc/ilc93/pdf/resolutions.pdf.
} 


\section{Acknowledgements}

This report was written by Sara Elder and Dorothea Schmidt of the ILO Employment Trends Team (Employment and Labour Market Analysis Department), directed by Lawrence Jeff Johnson. Specific thanks are due to Steven Kapsos for his ongoing support in the production of the Global Employment Trends Model from which the world and regional aggregates used in this report come, and to Yves Perardel for his data and research assistance. We would like to express our appreciation as well to José Manuel Salazar-Xirinachs for promoting this report as a contribution to the research efforts of the ILO Employment Sector's youth employment programme. The helpful and constructive comments from Rashid Amjad, Laura Brewer, Mariangels Fortuny, Stephen Pursey and Giovanna Rossignotti helped to improve the report tremendously. Julia Lee and Evelyn Ralph provided invaluable administrative and editorial support. Finally, the Employment Trends Team would like to express our appreciation to all individuals involved, within the ILO but also at the country level, in the collection and dissemination of labour market information. The analyses provided within the Global Employment Trends series are only as good as the input data available to us. We take this opportunity to encourage additional collection and dissemination of age-disaggregated data at the country level in order to improve the accuracy of the analyses of global employment trends for youth provided in future updates of this report. 


\section{Contents}

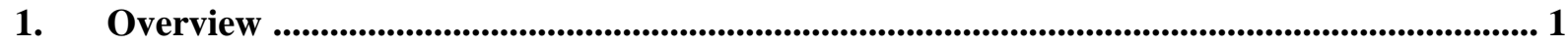

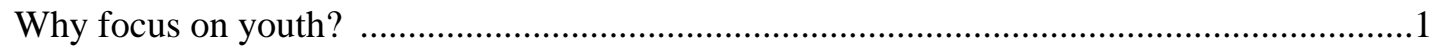

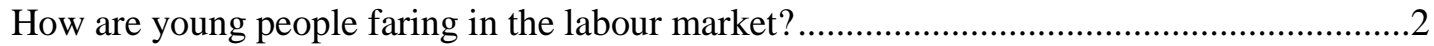

Misconceptions concerning youth and youth labour markets ...................................................6

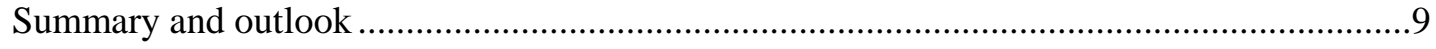

2. Labour market trends for youth .............................................................................................................11

2.1 Demographic trends and developments in youth labour force participation ....................11

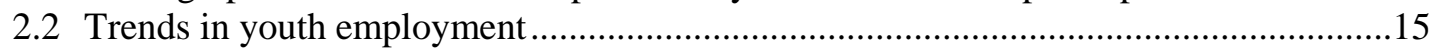

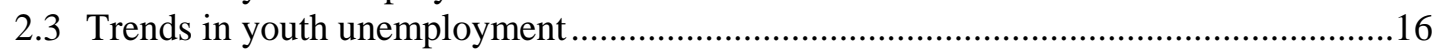

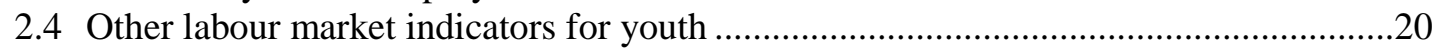

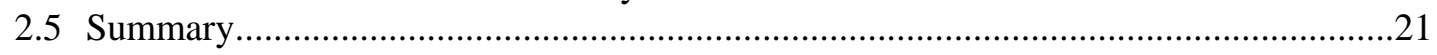

3. Trends in youth poverty and working poverty ............................................................................22

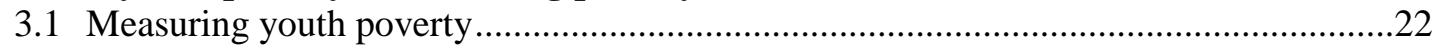

3.2 Going beyond youth poverty to youth working poverty ……........................................23

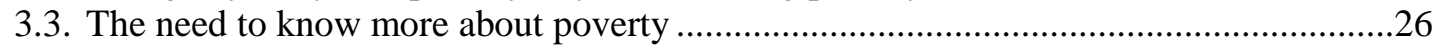

4. Explaining youth inactivity and labour market vulnerability .................................................28

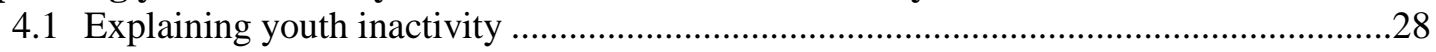

4.2 Explaining labour market vulnerability among youth ...................................................33

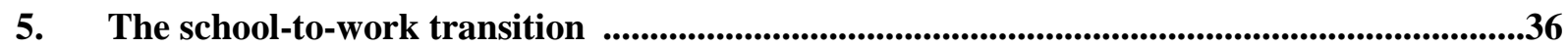

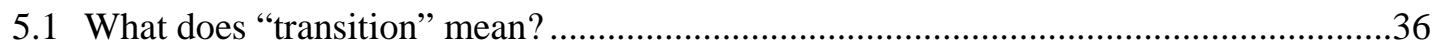

5.2 The ILO concept of the school-to-work transition: measuring the transition

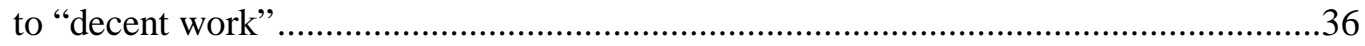

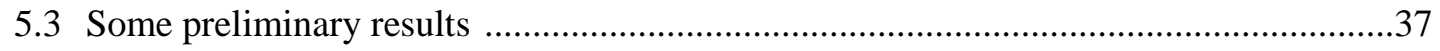

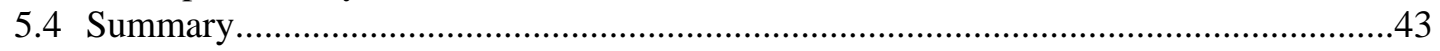

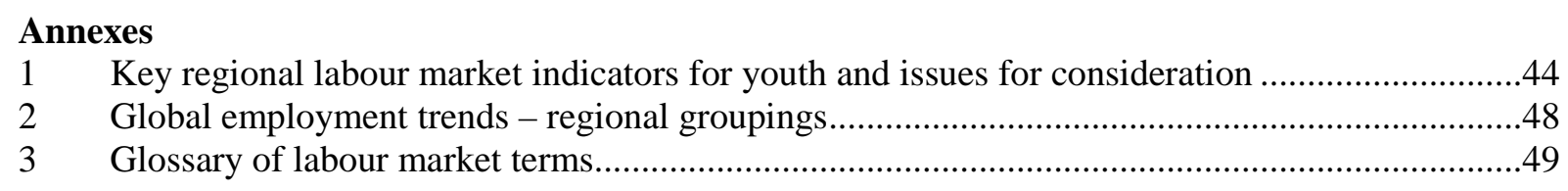

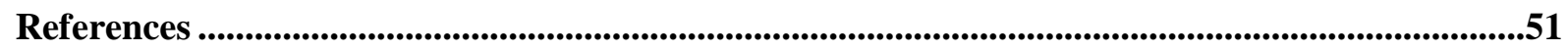

\section{Tables}

Table 2.1: Youth share in total working-age population, 1995 and 2005 .....................................13

Table 2.2: Development of the youth labour force and youth population between 1995 and 2005 and expected net growth of the youth labour force between 2005 and $2015 \ldots \ldots \ldots \ldots \ldots \ldots . . . . .13$

Table 2.3: Youth labour force participation rates, by sex, 1995 and 2005 .......................................15

Table 2.4: Youth employment and youth employment-to-population ratios .......................................16

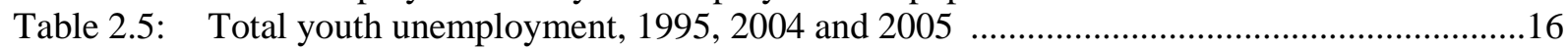

Table 2.6: Ratio of youth-to-adult unemployment rates, 1995 and 2005 ........................................18

Table 2.7: Youth share in total unemployed and youth share in total working-age population,

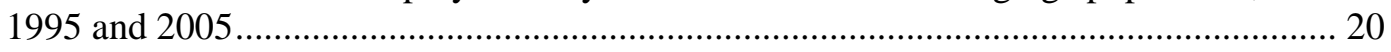

Table 3.1: Poverty estimates of undernourished young people (1999-2001) and young people living on less than US $\$ 1$ a day and US $\$ 2$ a day, by region, $2002 \ldots \ldots \ldots \ldots \ldots \ldots \ldots \ldots \ldots \ldots \ldots \ldots . . . .22$

Table 3.2: US\$1 and US\$2 a day working poverty among youth, total numbers and youth working poverty rates 
Table 4.1: Youth inactivity and inactivity rates (1995 and 2005) and female share of total

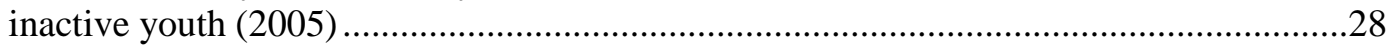

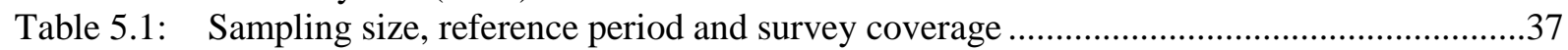

Table 5.2: Distribution of employed youth by type of employment contract .....................................38

Table 5.3: Distribution of youth in transition, by current activity status ...........................................39

Table 5.4: Distribution of youth outside of the labour force by reason for inactivity, by sex ............40

Table 5.5: Main obstacles to finding decent work identified by in-transit youth .................................40

Table 5.6: Transited youth by education level ................................................................................

Table 5.7: Most important factors influencing employers' decisions when hiring young men and women, by type of post (professional/administrative or manual/production) ...................42

Table 5.8: Employers' preferences of education level when hiring young men and women, by type of post (professional/administrative or manual/production) ................................42

Table 5.10: Employers' general skills assessment of young job applicants and young workers, by type of skill and overall general preparedness ............................................................42

Table 5.11: Sampling size, reference period and survey coverage ......................................................

\section{Figures}

Figure 1: What we do and do not know about the global youth labour market .................................5

Figure 2.1: Regional distribution of the youth population, 2005 and 2015 ......................................11

Figure 2.2: Population distribution by child, youth and adult age cohorts, by region, 1995, 2005

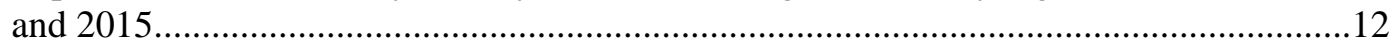

Figure 2.3: Global youth unemployment and youth unemployment rates, 1995-2005 .......................17

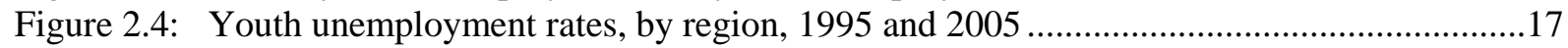

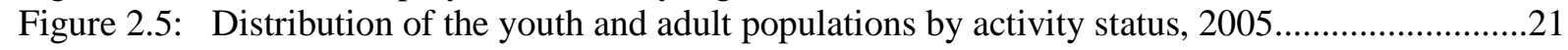

Figure 4.1: Youth inactivity rates and GDP per capita (at PPP), 2005 ...........................................29

Figure 4.2: Percentage change in gross enrolment ratios at the tertiary level and the percentage change in youth inactivity rates, by region, 1990-2002 ….............................................30

Figure 4.3: Share of youth neither in employment nor education (NEET) in total youth population,

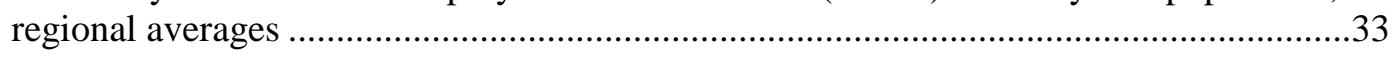

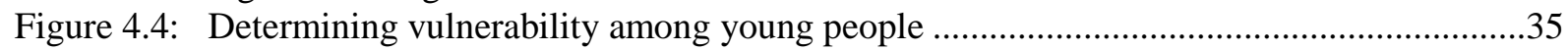

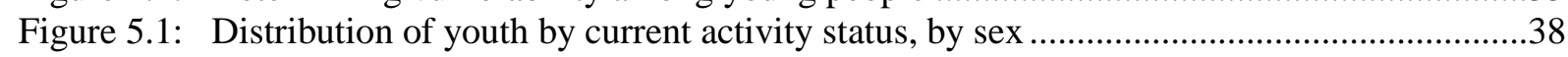

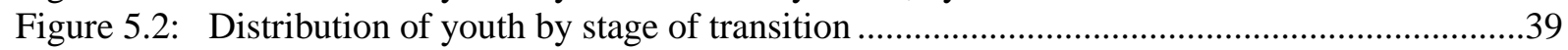

Figure 5.3: Distribution of educational level of respondents by stage of transition, Egypt and Nepal

Figure 5.4: Employers' general skills assessment of young job applicants and young workers, by type of skill and overall general preparedness

\section{Boxes}

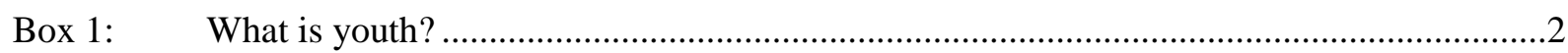

Box 2: $\quad$ ILO methodology for producing world and regional estimates of labour market

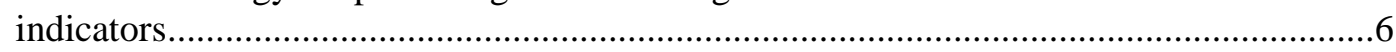

Box 2.1: Why are youth unemployment rates higher than adult unemployment rates?...................19

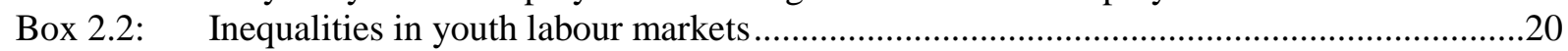

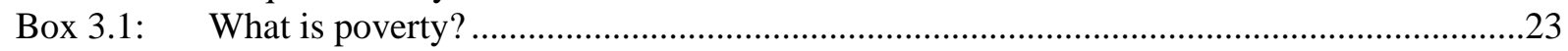

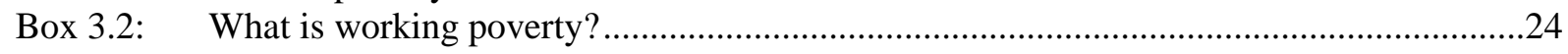

Box 3.3: Young girls and young refugees have the lowest chances to escape poverty ....................27 


\section{Overview}

Young women and men are among the world's greatest assets. They bring energy, talent and creativity to economies and create the foundations for future development. But today's youth also represent a group with serious vulnerabilities in the world of work. In recent years slowing global employment growth ${ }^{3}$ and increasing unemployment, underemployment and disillusionment have hit young people the hardest. As a result, today's youth are faced with a growing deficit of decent work opportunities and high levels of economic and social uncertainty.

The UN Secretary General recently called upon Heads of States to work to put an end to the vicious circle of youth unemployment, noting that youth are our most valuable asset, our future. ${ }^{4}$ The sentiment was further advanced by the Ministers and Heads of Delegations participating in the HighLevel Segment of the 2006 Substantive Session of the Economic and Social Council (ECOSOC) who committed themselves to "develop[ing] and implement[ing] strategies that give youth everywhere a real and equal opportunity to find full and productive employment and decent work" and reiterated their commitment "to mainstream youth employment into national development strategies and agendas; to develop policies and programmes for enhancing the employability of youth, including through education, training and lifelong learning that meet labour market requirements; and to promote access to work through integrated policies that enable the creation of new and quality jobs for young people and facilitate access to those jobs, including through information and training initiatives". This report uses the latest available information in order to analyze labour market conditions for young people and identify barriers that can stand in the way of realizing these global commitments. It highlights the importance of focusing on youth and provides the ingredients from which strategies can be developed to tackle one of the most urgent and widely recognized global challenges.

This second Global Employment Trends for Youth (2006) updates the world and regional youth labour market indicators presented in the first Global Employment Trends for Youth (2004) report (section 2). This report goes beyond this, however, to investigate the relationship between the lack of decent employment opportunities and poverty to explain why many young people remain poor despite the fact that they work (section 3). Section 4 of the report offers a more in-depth analysis of factors that explain one of the worrying indicators - inactivity - and the reasons for its increase in recent years. This section also offers a framework for identifying youth who are more vulnerable to getting stuck in labour market situations that will be detrimental to their own future development and to that of the economy at large. Section 5 focuses on the school-to-work transition to help countries pinpoint the specific challenges that young men and women face when entering the world of work so that the most appropriate policy mix can be determined to redress the situation within countries.

\section{Why focus on youth?}

Youth unemployment and situations in which young people give up on the job search ("discouragement") or work under inadequate conditions ("underemployment") incur costs to the economy, to society and to the individual and their family. A lack of decent work, if experienced at an early age, often permanently compromises a person's future employment prospects and frequently leads to unsuitable labour behaviour patterns that last a lifetime. There is a proven link between youth unemployment and social exclusion. ${ }^{6}$ An inability to find employment creates a sense of vulnerability, uselessness and idleness among young people. ${ }^{7}$ The most obvious gains then, in making the most of

\footnotetext{
${ }^{3}$ ILO, 2006c.

${ }^{4}$ Secretary-General's address to the 4th European Union/Latin America and Caribbean Heads of State Summit, Vienna, 12 May 2006; www.un.org/apps/sg/sgstats.asp?nid=2030.

${ }^{5}$ Reference is made to the Ministerial Declaration of the High-level Segment of ECOSOC to strengthen global efforts towards generating more decent work opportunities as necessary means for achieving the international development goals to cut the numbers of people living in extreme poverty by half by 2015. The Declaration builds on the work of the ILO to promote a decent work agenda for reducing poverty and obtaining equitable, inclusive and sustainable development. See ECOSOC High-level Segment: Ministerial Declaration, 5 July 2006, E/2006/L.8.

${ }^{6}$ See, for example, Ryan, 2000, and ECA, 2005.

${ }^{7}$ ILO, 2003, p. 25. See also UN, 2005, p. 46.
} 
the productive potential of youth and ensuring the availability of decent employment opportunities for youth, are the personal gains to the young people themselves.

\section{Box 1 \\ What is "youth"?}

This report defines youth as the 15 to 24 age group as this is a widely accepted statistical convention. (See UN, 1992.) Differences continue to exist, however, in the way many national statistics programmes define and measure youth.

Definitions of "youth" are based in part on the end use of the measurement. If one aims to measure, for example, the age span at which one is expected to enter the labour market then the statistical definition of 15 to 24 years may no longer be valid, given that today more and more young people postpone their entry into labour markets to well beyond the age of 25 . Alternatively, if one were to aim for the broader characteristic-based classification of youth (as opposed to a simple age-based definition), then a more sociological viewpoint on what constitutes "youth" is needed. For example, one might wish to define "youth" as the transition stage from childhood to adulthood, in which case the age at which this transition begins will vary greatly between societies and indeed within the same society. From the perspective of a critical stage in the lifecycle, the relevant age could be as low as 10 years (e.g. street kids) to as high as mid to late 30s. The wider age span suggests that the process of obtaining a sustaining livelihood, if that is taken as the basic criteria for passage into the next life stage adulthood - can take a long time, particularly in poor societies.

Sources: Curtain, 2002 and 2004. See also UN, 2005, p. 95, for further discussion on the blurring boundaries between youth and adults.

The second obvious gain to recapturing the productive potential of underutilized youth is an economic one. Idle youth is a costly group. They are not contributing to the economic welfare of the country - quite the contrary. The loss of income among the younger generation translates into a lack of savings as well as a loss of aggregate demand. Some youth who are unable to earn their own income have to be financially supported by the family, leaving less for spending and investments at the household level. Societies lose their investment in education. Governments fail to receive contributions to social security systems and are forced to increase spending on remedial services, including crime or drug use prevention efforts. All this is a threat to the development potential of economies. Focusing on youth, therefore, makes sense to a country from a costs-benefits point of view.

It is also important to focus on youth because they are the drivers of economic development in a country. Young people might lack experience but they tend to be highly motivated and capable of offering new ideas or insights. Foregoing this potential is an economic waste. In the 2004 report, the ILO estimated that halving the world's youth unemployment rate, and thus bringing it more in line with the adult rate while allowing for some natural differences, would add between an estimated US\$ 2.2 and 3.5 trillion of the 2003 value, or between 4.4 and 7.0 per cent, to the global GDP. ${ }^{8}$

\section{How are young people faring in the labour market?}

This basic question was addressed in the report of two years ago. Unfortunately, there has been little change in the general global trends for youth employment reported on in the previous report. Information from sections 2 and 3 of this report confirm the following:

\section{Some global trends}

- The global youth labour force, which is the sum of the employed youth and unemployed youth, grew from 602 to 633 million (by 5.2 per cent) between 1995 and 2005 and is projected to grow by another 24 million to 657 million in 2015 (table 2.2).

- The share of the youth labour force in the youth population (the youth labour force participation rate) decreased globally from 58.9 to 54.7 per cent between 1995 and 2005, which means that in 2005 only every second young person was actively participating in labour markets around the world. Conversely, the youth inactivity rate (as a measure of the share of young people who are

\footnotetext{
${ }^{8}$ GDP was measured in current PPP-adjusted dollars for 2003. The estimates were based on historical country-level GDP-toyouth employment elasticities.
} 
outside of the labour force in the youth population) rose from 41.1 to 45.3 per cent over the same period (tables 2.3 and 4.1).

- In 2005, the number of employed young people was 548 million, an increase of 20.1 million from ten years before. However, because the youth population grew at a quicker pace than youth employment, the share of youth who are employed in the youth population (the youth employment-to-population-ratio) saw a decrease from 51.6 to 47.3 per cent between 1995 and 2005 (table 2.4).

- The number of young unemployed increased from 74 million to 85 million between 1995 and 2005 , an increase of 14.8 per cent (table 2.5 ).

- The youth unemployment rate, a measure of the percentage of young people who are looking but unable to find work in the youth labour force, stood at 13.5 per cent in 2005 (compared to 6.4 per cent for the overall global unemployment rate ${ }^{9}$ and 4.5 per cent for the adult unemployment rate) (figure 2.3). ${ }^{10}$

- Compared to adults, the youth of today are still more than three times as likely to be unemployed; the ratio of the youth-to-adult unemployment rate was 3.0 in 2005, up from 2.8 in 1995 (see table 2.6).

- The youth unemployed make up almost half (43.7 per cent) of the world's total unemployed despite the fact that, in comparison, the youth share of the total working-age population (ages 15 and over) was only 25.0 per cent (table 2.7 ).

- There are an estimated 125 million young working poor, meaning more than 20 per cent of employed youth lived in a household where there was less than US $\$ 1$ a day available per head in 2005. There were approximately 300 million young working poor at the US $\$ 2$ a day level - more than one half of all young women and men who worked - in the same year (table 3.2).

\section{Some regional trends ${ }^{11}$}

- As much as 89 per cent of the world's youth were living in developing economies in 2005.

- Youth labour force growth will continue to be concentrated in sub-Saharan Africa, South East Asia and the Pacific, and in the Middle East and North Africa - regions where insufficient economic demand already results in significant unemployment rates for youth. Between 1995 and 2005, these regions are projected to add another 24 million, 11 million and 865,000 young labour market participants, respectively. In the meantime, the size of the youth labour force will decrease in all other regions, and most considerably in East Asia (table 2.2).

- Youth labour force participation rates were highest in East Asia (67.3 per cent) and sub-Saharan Africa (65.5 per cent) in 2005. The lowest rate was that of the Middle East and North Africa (40.0 per cent). Labour force participation rates decreased during the last decade in all regions for young men, whereas for young women it decreased in all regions except the Middle East and North Africa and Latin America and the Caribbean (table 2.3).

- The only region where the youth employment-to-population ratio increased between 1995 and 2005 was the Middle East and North Africa, which is noteworthy given the tremendous growth of the youth population in the region of over 30 per cent during this period that the labour market has had to accommodate. But at the same time the region still had the lowest youth employment-topopulation ratio at 29.7. East Asia had the highest employment-to-population ratio at 62.1 but also the second biggest decrease over the last ten years of -10.6 per cent (behind an 11.8 per cent decrease in Central and Eastern Europe (non-EU) and CIS). All other regions witnessed decreases

\footnotetext{
${ }^{9}$ The latest ILO world and regional estimates of labour market indicators for the aggregate population are available from ILO, 2006c.

${ }^{10}$ Differences to earlier estimates (in the 2004 report) are due to the fact that more country level data were available for input into the model used to generate missing country values for the aggregation to world and regional levels (see box 2). Other input data used in the estimation model have changed as well, including revisions of the IMF estimates of GDP growth.

${ }^{11}$ See the text in section 2 and Annex 1 for more regional highlights.
} 
as well with the exception of the Developed Economies and European Union where it stayed more or less stable over the decade (table 2.4).

- Most regions saw increases in the number of unemployed youth between 1995 and 2005. The largest increase of 85.5 per cent (from 5.2 to 9.7 million) was in South East Asia and the Pacific, followed by 34.2 per cent (from 13.0 to 17.4 million) in sub-Saharan Africa, 23.0 per cent (from 7.7 to 9.5 million) in Latin America and the Caribbean, 18.2 per cent (from 7.2 to 8.5 million) in the Middle East and North Africa, and 16.1 per cent in South Asia (from 11.8 to 13.7 million) (table 2.5).

- The highest regional youth unemployment rate can be observed in the Middle East and North Africa at 25.7 per cent in 2005. Central and Eastern Europe (non-EU) and CIS had the second highest rate at 19.9 per cent. Sub-Saharan Africa's rate was 18.1 per cent, followed by Latin America and the Caribbean (16.6 per cent), South East Asia and the Pacific (15.8 per cent), the Developed Economies and European Union (13.1 per cent), South Asia (10 per cent) and East Asia (7.8 per cent). The only region that saw a considerable decrease over the last ten years was the Developed Economies and European Union (figure 2.4).

- In most regions youth were nearly three times more likely to be unemployed than adults. The only exceptions were the Developed Economies and European Union where youth unemployment was only 2.3 times higher than adult unemployment in 2005 and, on the other end of the scale, South East Asia and the Pacific, where youth unemployment was more than 5 times higher than adult unemployment (table 2.6).

- In all regions, youth have higher shares of unemployment and inactivity and lower employment shares compared to adults (figure 2.5).

- Working poverty among youth is most alarming for sub-Saharan Africa, the only region that has seen a sharp and continuous increase of the total number of youth working poor at the US\$1 a day level (from 36 million to 45 million between 1995 and 2005). Extreme working poverty is also still a big problem in South Asia, where almost 4 out of 10 young people work but remain poor. But at least the long term trend has shown some improvement in the region; ten years ago, almost 6 out of 10 young working people were US\$1 a day working poor, which was almost as much as in sub-Saharan Africa (table 3.2).

- Youth US\$2 a day working poverty decreased most in the regions of Central and Eastern Europe (non-EU) and CIS and in East Asia. In South Asia and sub-Saharan Africa only one out of ten young people earn enough to lift themselves together with their families above the threshold of US\$2 a day.

The two diagrams in figure 1 show what it is possible to quantify given the current state of labour market statistics for young people within the global community. Sufficient country-level information exist to allow the classification of the youth population into three main activity groups: a) employed, b) unemployed and c) outside of the labour force, or "inactive" (using the Global Employment Trends Model described in box 2). Consequently, this provides the basis for the findings highlighted in the bullet points above concerning the global youth labour market. It is also possible to identify two negative trends that have occurred over the last ten years: there was a decreasing share of employed youth in the total youth population (from 51.6 to 47.3 per cent) and an increasing share of unemployed youth (from 7.3 to 7.4 per cent $^{12}$ ). In addition, the share of the youth population who are inactive (outside of the labour force) increased from 41.1 to 45.3 per cent.

A deficit of decent work opportunities impacts not only young people who are looking but unable to find employment - the unemployed - but also results in a situation where young women and men work under poor conditions (the "underemployed"13) or involuntarily fall outside of the labour

\footnotetext{
${ }^{12}$ The share of unemployed youth in the youth population given here is not the same as the youth unemployment rate since the youth unemployment rate is the share of unemployed youth in the youth labour force. See Annex 3 for a more detailed glossary of labour market terms.

${ }^{13}$ Underemployment reflects underutilization of the labour force and has been broadly interpreted to imply any sort of employment that is "unsatisfactory" (as perceived by the workers) in terms of insufficient hours (time-related underemployment), insufficient compensation (income-related underemployment) or insufficient use of ones skills (skills-
} 
force due to their belief that there is no work available for them (the "discouraged workers"14). Regardless of their economic activity status (employed, unemployed or inactive), young people who are not able to make the most of their productive potential are susceptible to feelings of despondency, to marginalization and impoverishment, to idleness and potential attraction to illicit activities, to feeling frustrated with their situation and to directing their anger and frustration at the society that created it. These are the young people who would benefit the most from policy interventions aimed to increase decent work opportunities for youth.

\section{Figure 1}

What we do and do not know about the global youth labour market
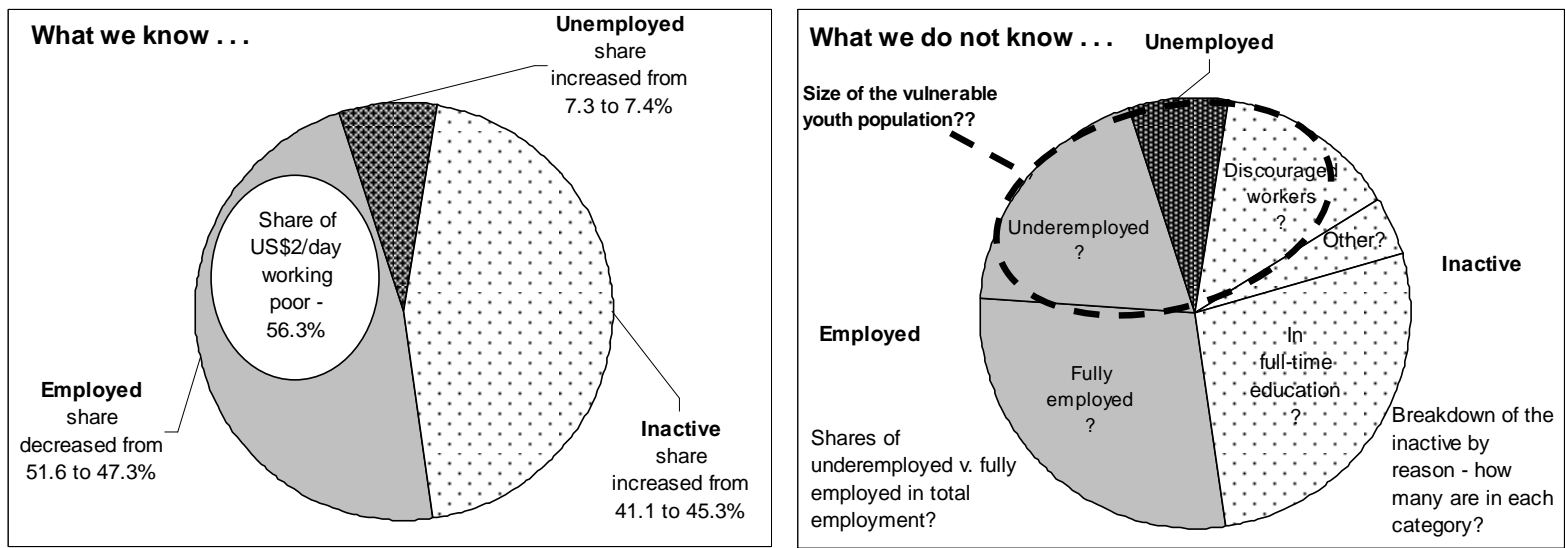

The calculation of the full extent of a decent work deficit for young people, therefore, would require data on the number of unemployed youth, the number of underemployed youth and the number of discouraged youth. Unfortunately, due to a lack of country level data, the ILO cannot quantify at the global or regional level either: 1) the distribution of the employed youth who are fully employed versus underemployed or 2) the share among inactive youth who are inactive because they are in fulltime education, because they have become discouraged with the job search (the discouraged workers) or for other reasons (inactivity by reason is discussed at greater length in section 4). Therefore, at this time, it is not possible to precisely calculate the full extent of the deficit of decent work opportunities and the size of the vulnerable youth population who fall within the deficit.

What is possible, however, is to generate a fair approximation of the youth population who fall within the decent work opportunity deficit based on two assumptions: first, that the number of young people who work, yet live in households that have less than US\$2 a day per person (the US\$2 a day working poor, as calculated in section 3 ) is a sound proxy for income-related underemployment, and second, that discouraged youth are likely to constitute at least 4 per cent of the inactive youth population. $^{15}$ The ILO estimates, therefore, that currently 85 million unemployed youth, 300 million working poor youth at the US\$2 a day level and 20 million discouraged youth, or a total of 400 million young people, are impacted by a current deficit of decent work opportunities. In other words, approximately 35 per cent of the youth population, or one in three youth, suffers from an inability to find or maintain decent work that allows them to fulfill their economic potential while earning sufficient returns to lift themselves and their families above the poverty line.

related underemployment). To date, time-related underemployment is the only component of underemployment that has been agreed on and properly defined for measurement purposes within the international community of labour statisticians. See the Resolution concerning the measurement of underemployment and inadequate employment situations, adopted by the 16th International Conference of Labour Statisticians, Geneva, 1998;

www.ilo.org/public/english/bureau/stat/download/res/underemp.pdf.

${ }^{14}$ For a more technical discussion of discouraged workers and the complexities of measurement, see ILO, 1990, pp. 107-08. See also section 4 of this report.

${ }^{15}$ Using data from the only collection of statistics on discouraged workers, that of the Organisation for Economic Cooperation and Development (OECD), we calculated that among OECD countries the share of young discouraged workers in the youth population outside of the labour force (inactive youth) was 2.6 per cent in 2004 . We estimate that the global share of young discouraged workers would be slightly higher -4 per cent - due to a higher presence of discouragement in some regions, for example, in Central and Eastern Europe (non-EU) and CIS. Four per cent of 525 million inactive youth comes to approximately 20 million discouraged youth. 


\section{ILO methodology for producing world and regional estimates of labour market indicators}

In an ideal world, producing world and regional estimates of labour market indicators, such as youth employment, for example, would simply require summing up the total number of employed persons aged 15 to 24 years across all countries in the world or within a given region. However, because not all countries report data in every year and, indeed, some countries do not report data for any years at all, it is not possible to derive aggregate estimates of labour market indicators by merely summing up across countries. The biggest challenge in the production of aggregate estimates is thereby that of missing data.

To address the problem of missing data, the ILO has designed, and actively maintains, three econometric models which are used to produce estimates of labour market indicators in the countries and years for which no real data exist. The Global Employment Trends Model (GET Model) is used to produce estimates - disaggregated by age and sex - of unemployment, employment, employment by sector and employment elasticities. The world and regional labour force estimates discussed in this paper are estimated using the Trends Labour Force Model (TLF Model), and finally, the working poor estimates used in section 3 come from the Trends Working Poverty Model (TWP Model).

Each of these models uses multivariate regression techniques to impute missing values at the country level. The first step in each model is to assemble every known piece of real information (i.e. every real data point) for each indicator in question. It is important to note that only data that are national in coverage and comparable across countries and over time are used as inputs. This is an important selection criterion when the models are run, because they are designed to use the relationship between the various labour market indicators and their macroeconomic correlates (such as per capita GDP, GDP growth rates, demographic trends, country membership in the Highly Indebted Poor Country (HIPC) Initiative, geographic indicators and country and time dummy variables) in order to produce estimates of the labour market indicators where no data exist. Thus, the comparability of the labour market data that are used as inputs in the imputation models is essential to ensure that the models capture as accurately as possible the relationship between the labour market indicators and the macroeconomic variables. The last step of the estimation procedure occurs once the datasets containing both the real and imputed labour market data have been assembled. In this step, the ILO Trends Team aggregates the data across countries to produce the final world and regional estimates.

For further information on the world and regional econometric models, readers can consult the following technical background papers: Crespi, 2004, Kapsos, 2004 and (forthcoming) 2006.

\section{Misconceptions concerning youth and youth labour markets}

Overcoming prejudices regarding youth labour markets is an important step toward redefining old strategies and developing new ones that really get to the root of the youth labour market challenges. Misconceptions, such as those identified below, often result from insufficient labour market information or inadequate analyses of labour market information. Strengthening the capacity for labour market information collection and dissemination within countries and capacity building on the usages of information by policy-makers and young people themselves will be key to ensuring that misconceptions are cleared up and that policies and programmes are based on the actual needs of young people as identified through careful analysis.

\section{Misconception 1: Access to education is no longer a problem for young people.}

It is true that education enrolment is on the rise around the world and more young people are going to school and staying in school for longer periods of time; out of 163 countries with data available on gross enrollment rates in secondary-level education, 137 saw increased rates over the period 1990 to 2002. Gross enrollment rates also increased at the tertiary level in 124 out of 144 countries. ${ }^{16}$ Yet low enrolment rates remain a substantial problem in many countries ${ }^{17}$, as does illiteracy. In sub-Saharan Africa and South Asia more than a third of the youth population was still illiterate in $2002 .{ }^{18}$ Access to education remains a luxury that many households simply cannot afford

\footnotetext{
${ }^{16}$ Gross enrollment rates are from World Bank, 2005.

${ }^{17}$ On average, the secondary enrolment rate in sub-Saharan Africa was still quite low at 35 per cent in 2001. The only other region where the number of persons enrolled in secondary education was less than half of the population of the corresponding age group was South Asia at 45 per cent. (Source: Authors' calculations based on World Bank, 2005.)

${ }^{18}$ Countries with youth illiteracy rates in excess of 33 per cent in the latest year of data availability (typically 2002) include Bangladesh, Benin, Burkina Faso, Central African Republic, Chad, Comoros, Côte d'Ivoire, Ethiopia, Haiti, Mali, Mauritania, Mozambique, Niger, Pakistan, Papua New Guinea, Senegal and Sierra Leone. Data are from ILO, 2005a, table $14 \mathrm{c}$.
} 
for their children. So, while it is true that many young people, as well as societies, are benefiting from improved education levels, it is important to remember that the gains are far from universal and that special attention still needs to be paid to promoting free and universal education in poor countries where the opportunity costs to young people and their families of staying in school are prohibitively high.

Misconception 2: Because young people today are better educated than ever they will have less trouble finding work.

This statement assumes that there is sufficient demand for educated youth so that the young person holding a higher level degree will have no difficulty finding work. This is true in some developed economies, but in many developing economies, where economic development has not kept pace with the increases in educational attainment and/or the educational system has not provided young people with the skills most needed in the economy, the high unemployment rates of youth with higher education degrees show otherwise.

Misconception 3: Young people like to "shop around" to find the best job. Therefore, they will choose to take up numerous short-term, temporary posts in order to gain experience and find the "best fit".

A young person can "shop around" for the best job only in an economy with robust economic growth that results in strong demand by employers for her/his particular skills. A good example would be the strong demand for computer programmers in the United States in the 1990s that resulted in a situation in which the prospective computer programmer could "bargain" for the best employment contract terms and could choose to change jobs even numerous times in one year. The system of moving in and out of temporary employment and only eventually (if ever) into permanent employment, worked for some young people in a boom economy like that of the United States in the 1990 s, but the situation there was clearly unique.

Where there is little economic growth or a shrinking employment content of growth (measured with employment elasticities), ${ }^{19}$ there is unlikely to be an opportunities to shop around for the best job. If a young person in a poor country is lucky enough to find work in the formal sector, s/he will be unlikely to change jobs, even if the job does not make good use of her/his talents. Security will overrule job satisfaction as a motivator for young employees in low-income countries. Therefore, short job tenure and "shopping around" is a phenomenon almost exclusively pertaining to developed economies or of wealthier youth in developing economies. It certainly cannot explain the fact that youth are over three times more likely to be affected by unemployment than adults.

Even in developed economies, however, the desire of young people for job security remains a primary concern. France is a case in point. In February 2006 the Government of France introduced the "first employment contract" (Contrat Première Embauche, CPE) with the aim of encouraging companies to hire young people by introducing a flexible system allowing them to hire those under the age of 26 for a period of two years during which the employee could be dismissed at any time and for any reason. Widespread popular opposition to the reduction in job security for young people that the introduction of the CPE was perceived to create led to its early withdrawal.

\section{Misconception 4: Unemployment is the key labour market challenge for youth.}

Youth unemployment is only the tip of the iceberg. Although more difficult to quantify, there are two other groups that together outnumber the unemployed youth but suffer from the same frustrations as the unemployed: the discouraged youth and the working poor. In countries without effective unemployment support mechanisms, concentrating on unemployment also runs the risk of excluding from the analysis the less privileged population who simply cannot afford to be unemployed. In several developing countries, young people of higher socio-economic backgrounds are over-represented in the unemployment numbers because it is only they who can afford to spend time looking for work, without incoming wages. The problem is not so much unemployment, therefore, in developing countries but rather the conditions of work of those who are employed. In such cases the indicators mentioned in section 2 which relate more to conditions of work would be a much more informative gauge of the labour market situation of youth.

\footnotetext{
${ }^{19}$ See "Trends in the employment intensity of economic growth" in ILO, 2005a, Chapter 1.
} 
Misconception 5: Youth unemployment rates give an accurate picture of youth labour market challenges.

This misconception is closely related to the previous one. If we accept that some young people who are working (the working poor, young workers without a contract, young people in hazardous work, as examples) and some young people who are inactive (the discouraged workers) are also in situations that place them far from the goal of achieving full and productive employment, then looking at youth unemployment rates to the exclusion of other indicators would mean ignoring a large portion of the youth population that requires equal attention by policy-makers aiming to improve the productive potential of youth populations. Indicators such as the youth labour force participation rate, employment-to-population ratio, employment by status or sector and the share of young people who are neither in employment nor in education in the youth population should be used to balance the youth unemployment rates when making a general assessment of youth labour market challenges.

An additional criticism of the aggregate unemployment rate for youth is that it masks information on the composition of the young jobless population and therefore misses out on the particularities of the education level, ethnic origin, socio-economic background, work experience, etc., of the unemployed. ${ }^{20}$ Moreover, the unemployment rate says nothing about the type of unemployment (is it cyclical or structural?), which is a critical issue for policy-makers in the development of their policy responses (structural unemployment cannot be addressed by boosting market demand only).

Misconception 6: Youth are a homogenous group and strategies to tackle youth labour market challenges can be uniformly applied within and across countries.

Perhaps this is the most blatant misconception. A young person born in Burundi cannot be compared to a young person in, say, China in terms of the opportunities and constraints placed before them. And even within countries, there are numerous subgroups of youth that face discrimination based on their ethnicity, age, family background or geographic location. (See box 2.2.) Numerous illustrations in this report identify youth who face specific challenges in the search for decent work young migrants, young women, youth in rural areas, young refugees. Youth are not a homogenous group which is why targeted interventions aimed at overcoming the specific disadvantages that some youth face in entering and remaining in the labour market will be warranted. What is important to remember is that despite the individual characteristics that make up each young person, where youth are equal to one another is in their right to strive for and obtain full and productive employment.

Misconception 7: With many young people migrating to urban areas, there is no pressing need to address the labour market challenges of young people living in rural areas.

Despite increasing numbers of young people who migrate from rural to urban areas in search of better opportunities, focusing on the development of young people in rural areas still makes sense for several reasons. First, the agricultural sector (and thus rural areas) still accounts for more than 40 per cent of total employment in the world and is still the dominant sector for employment in East Asia, South East Asia and the Pacific, South Asia and sub-Saharan Africa. ${ }^{21}$ Improving wages and productivity within the rural economy - through poverty reduction strategies, improvements in infrastructure, programmes that promote savings and innovation, development of the rural non-farm sector, etc. - could go a long way toward promoting the structural transformation of rural areas that would in turn stem the tide of rural to urban migration among young people. ${ }^{22}$ Second, unemployment rates tend to be even higher in crowded, urban cities where increasing numbers of rural migrants compete for limited numbers of jobs. Investing in youth in rural areas in a way that decreases their likelihood of migrating would, therefore, have the side effect of helping to improve conditions for young people in urban areas. Finally, it has been shown that employment creation in rural areas has a higher impact on poverty reduction than in urban areas simply because poverty tends to be concentrated in rural areas. $^{23}$

\footnotetext{
${ }^{20}$ Godfrey, 2003.

${ }^{21}$ ILO, 2006c, table 5.

${ }^{22}$ For more information on structural transformation as a means to "break away" from poverty, particularly in Africa, see UN, 2005, chapter 4.

${ }^{23} \mathrm{UN}, 2005$, p. 129 estimates that 70 per cent of poor people in Africa are living in rural areas.
} 


\section{Misconception 8: Young people are poor because they do not work.}

There are many contexts in which poverty occurs. Some people are poor but are supported by social safety nets - either formal in the terms of government support or informal support within the family - which may or may not be "generous" enough to allow them to survive without working. Some people live in poverty that results in malnourishment and sickness which leaves them unable to work. ${ }^{24}$ But for the most part, there are people living in extreme poverty who lack social safety nets and must therefore try to survive by any means possible - through ingenuity, courage, self-discipline and most of all through work. ${ }^{25}$ No opportunity to earn some money or payment in kind for oneself or one's family can be missed. Young people living in extremely poor families also have to work in some way or other, usually at the bare subsistence level. The data on the youth working poor presented in section 3 offer the best proof against this misconception. At the global level, as many as 125 million young people live in households where the income comes to less than US $\$ 1$ a day per household member despite the fact that they work. So almost 23 per cent of young people are extremely poor (US\$1 a day level) despite the fact that they work. Even more dramatic is the estimate that as much as 56 per cent of young people who work remain poor at the US\$2 a day level.

Misconception 9: It is better to gear job creation programmes toward adult jobseekers rather than youth jobseekers because adult jobseekers will need the wages more than the young to support their families.

If one were able to measure the immediate need of the jobseeker and distribute jobs according to need, then perhaps it would make sense to give a post to an adult who is the sole support of a household of five rather than to a young person who could still rely on the financial support of his/her parents. But how accurate is the generalization that adults have greater financial need than youth? A young person might also have branched out from the family to start up his/her own household in which case the need would be the same. But in the absence of such information, we come back to the core question of: does it really matter? Unemployment has its costs, at least if experienced for a long period or over multiple periods, in terms of loss of self-esteem, loss of income and social exclusion, and there is no reason to suppose that one segment of society can bear the costs better than another. In effect, there is growing evidence to the fact that being unemployed at an early age has a direct negative impact on future income streams. For instance, research has shown that a young person whose first experience in the labour market is one of long-term unemployment is likely to move between stages of unemployment and low-wage employment throughout the rest of his/her working life.$^{26}$ Bearing the long-term costs in mind, focusing job creation efforts on young people in an attempt to reverse these trends and giving youth the opportunity to become more active and productive participants in the workforce makes sense. However, employment policies targeted at young people should be integrated into overall employment strategies at the national level so as not to isolate one segment of society to the detriment of others.

\section{Summary and outlook}

The case for investing in youth, although reiterated at the level of rhetoric, is unfortunately not often enough put into practice. The challenge is for governments, employers' organizations, trade unions, international development partners and civil society bodies to tap into this vast productive potential. Investment in job creation and increased employability for young men and women could provide massive returns. Indeed, the ILO estimates that halving the rate of youth unemployment could have added an estimated US\$ 2.2 to 3.5 trillion to the world economy in 2003 . This represented 4.4 to 7 per cent of the 2003 value of global GDP.

The data available reveal several negative trends with respect to youth labour markets, among which are the decreasing share of employed youth and the increasing share of unemployed youth in the youth population and the persistence of poverty among as much as 56 per cent of young workers. Taking into account the unemployed youth ( 85 million), the working poor youth (300 million at the US\$2 a day level) and discouraged youth (roughly approximated at 20 million), the ILO estimates that

\footnotetext{
${ }^{24}$ The UN estimated that there were a total of 160 million severely undernourished young people in the world (see section 3 , table 3.1).

${ }^{25}$ ILO, 2003.

${ }^{26}$ See, for example, Gregg and Tominey, 2004.
} 
at least 400 million decent employment opportunities are needed in order to reach the full productive potential of today's youth. This figure is conservative since it does not cover the young people who are already working but working under poor conditions not related to remuneration (lack of contract, long hours, etc.). But underestimated or not, the assumption that more than one third of the youth population suffers from a deficit of decent work opportunities is striking enough for concern. Imagine what a difference it would make if all this wasted potential was tapped. Creation of decent work opportunities for young people should be the priority in terms of turning what is currently wasted productive capacity in large parts of the world into a positive force for development.

Attaining and maintaining decent employment - work that offers a worker a good income, security, flexibility, protection and a voice at work - is a challenge for any person. The importance of starting off right is perhaps even more urgent for young people since it is the initial transition to the labour force that is most significant in determining the economic (and social) well-being of the individual and, if taken collectively, in determining the level of development of the country. Without the proper foothold from which to start out right in the labour market, young people are less able to make choices that will improve their own job prospects and those of their future dependants, thus perpetuating the cycle of insufficient education, low productivity employment and poverty from one generation to the next. 


\section{Labour market trends for youth}

\subsection{Demographic trends and developments in youth labour force participation}

Population growth is slowing down but the poorest regions still face the greatest need for decent job creation

The share of the world's youth population in developing countries continues to increase while the share in the developed countries decreases, despite declining fertility rates in most developing countries. As much as 89 per cent of the world's youth were living in developing economies in 2005 . The three Asian regions alone - East Asia, South-East Asia and the Pacific and South Asia - together accounted for more than half (54 per cent) of the world youth population. Two developing regions South Asia and sub-Saharan Africa - are expected to see large increases in youth populations between 2005 and 2015 and are therefore the two regions whose shares of the world's total population are expected to increase. The world's share of youth living in sub-Saharan Africa will increase from 13 per cent to 15 per cent while the global share of youth in South Asia is expected to increase from 25 to 28 per cent. (See figure 2.1.)

Figure 2.1

Regional distribution of the youth population, 2005 and 2015
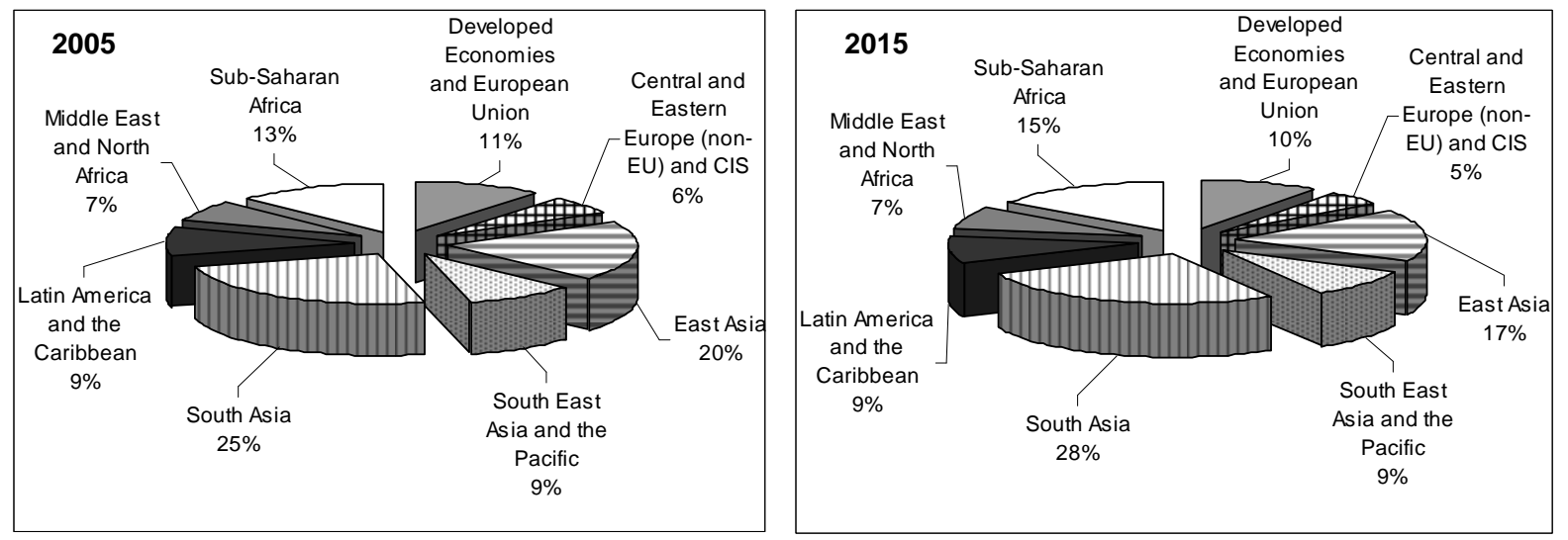

Source: ILO, Global Employment Trends (GET) Model, 2006 (see box 2 for more information) (2005 estimates) and ILO, Economically Active Population and Projections (EAPAP) database; available at http://laborsta.ilo.org (2015 estimates).

Nonetheless, as is evident from the charts in figure 2.2 showing the regional population distributions by age group - 0 to 14 years (children), 15 to 24 years (youth) and 25 years and over (adults) - in all regions the youth share in the overall population is declining, a clear sign that the developing world is nearing the final stage of the demographic transition. ${ }^{27}$ However, the youth share in total population remains on markedly different levels across regions and is declining at different rates. The youth cohort will still make up approximately one-fifth of the total population by 2015 in the regions of sub-Saharan Africa (20.8 per cent), South Asia (19.2 per cent), South East Asia and the Pacific (18.1 per cent) and the Middle East and North Africa (18.0 per cent).

From population trends to working-age population trends ...

If we look instead at the share of youth in the total working-age population (typically ages 15 years and over) we also expect to see a decrease in all regions in the years to come, but the difference between the regions regarding the size of this share is considerable (see table 2.1). The youth share in working-age population is highest in sub-Saharan Africa (36.9 per cent), followed by 32.6 per cent in the Middle East and North Africa, 29.3 per cent in South Asia, 27.5 per cent in South East Asia and the Pacific, 22.1 per cent in Central and Eastern Europe (non-EU) and CIS, 20.9 per cent in East Asia, and 15.7 per cent in Developed Economies and European Union. Disturbingly, it is the regions with

\footnotetext{
${ }^{27}$ In general, a country proceeds through three stages of demographic shifts: in the first stage, the proportion of the young in the population rises; in the second stage, the proportion of young people declines, that of the elderly cohort (aged 65+) increases modestly and, most importantly, that of adults (aged 25-64) increases sharply; finally, in the third stage, the proportion of adults falls while that of old people rises.
} 
Figure 2.2

Population distribution by child, youth and adult age cohorts, by region, 1995, 2005 and 2015
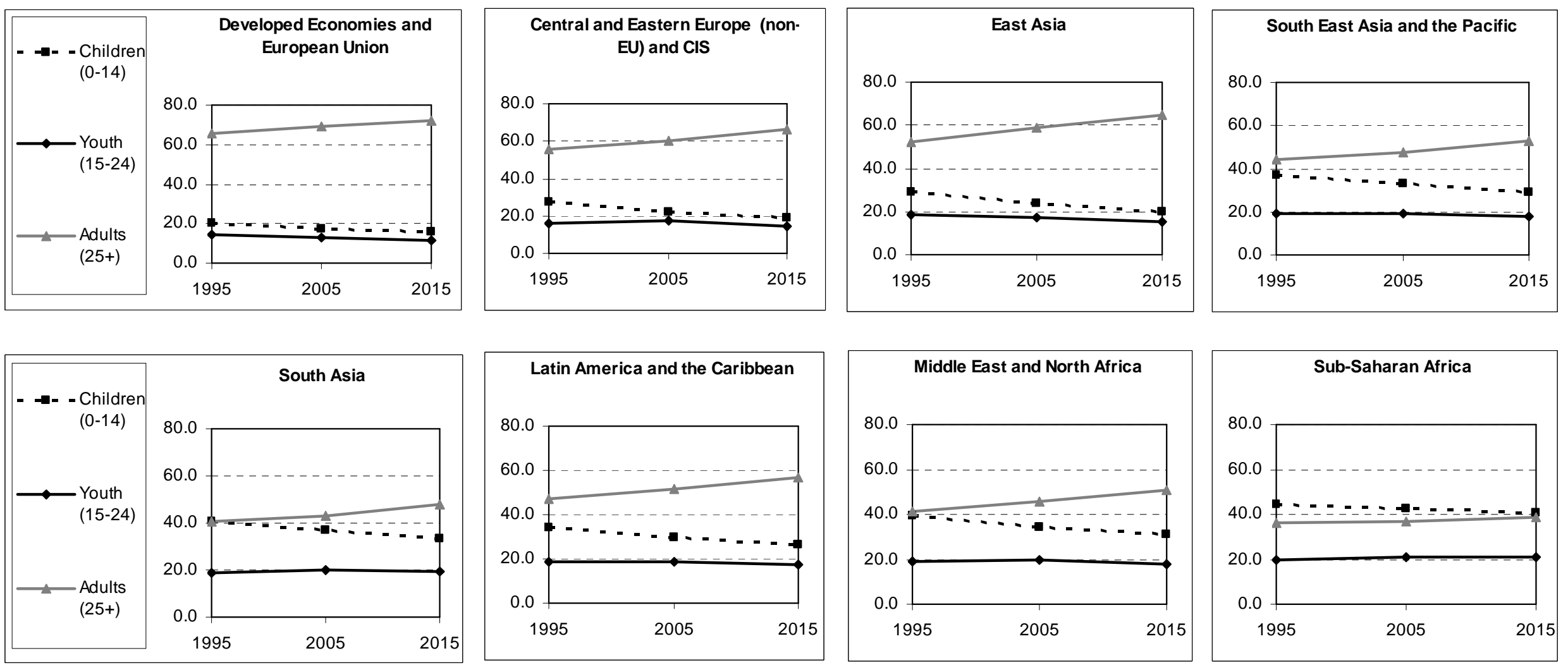

Note: The child cohort is persons aged 0-14 years, youth aged 15-24, and adults aged $25+$

Sources: Population shares are authors' calculations based on UN, World Population Prospects: The 2004 Revision Population Database, Panel 2: Detailed data, median variant; http://esa.un.org/unpp/. 
the higher share that performed less well in terms of economic development over the last decade which makes it especially hard to create enough decent jobs for young people. In the case of South Asia and sub-Saharan Africa, these are also the regions where poverty rates are the highest and which struggle the most with creating a sufficient amount of decent jobs to allow the population to "work out of poverty". ${ }^{28}$ It is in these regions that future prospects for young people are most pessimistic.

Table 2.1

Youth share in total working-age population, 1995 and 2005

\begin{tabular}{|l|c|c|}
\hline & \multicolumn{1}{|c|}{$\begin{array}{c}\text { Youth share in total working-age } \\
\text { population (\%) }\end{array}$} \\
\hline & 1995 & 2005 \\
\hline World & 26.3 & 25.0 \\
\hline Developed Economies and European Union & 17.2 & 15.7 \\
\hline Central and Eastern Europe (non-EU) and CIS & 21.6 & 22.1 \\
\hline East Asia & 24.6 & 20.9 \\
\hline South East Asia and the Pacific & 30.7 & 27.5 \\
\hline South Asia & 30.0 & 29.3 \\
\hline Latin America and the Caribbean & 30.0 & 26.9 \\
\hline Middle East and North Africa & 33.5 & 32.6 \\
\hline Sub-Saharan Africa & 35.7 & 36.9 \\
\hline
\end{tabular}

... to labour force trends

The labour force is the sum of employed persons and unemployed person (see Annex 3 for a full glossary of labour market terms). There is no clear short-term correlation between the population size of the youth cohort and the size of the youth labour force, but, as seen in table 2.2, in those cases where the youth population grew rapidly between 1995 and 2005, there is a large, albeit lesser, corresponding growth in the size of the labour force. Over the last ten years, large increases in the youth population have been accompanied by significant youth labour force growth in South Asia, the Middle East and North Africa and sub-Saharan Africa.

Table 2.2

Development of the youth labour force and youth population between 1995 and 2005 and expected net growth of the youth labour force between 2005 and 2015

\begin{tabular}{|c|c|c|c|c|c|c|c|c|}
\hline & \multicolumn{5}{|c|}{ Youth labour force ('000s) } & \multicolumn{3}{|c|}{ Youth population ('000s) } \\
\hline & 1995 & 2005 & 2015 & $\begin{array}{c}\% \\
\text { change } \\
1995- \\
2005 \\
\end{array}$ & $\begin{array}{c}\text { Net } \\
\text { growth } \\
2005- \\
2015 \\
\text { ('000s) }\end{array}$ & 1995 & 2005 & $\begin{array}{c}\% \\
\text { change } \\
1995- \\
2005 \\
\end{array}$ \\
\hline World & $602 ' 188$ & $633 ' 255$ & $657 ' 209$ & 5.2 & $23 ' 955$ & 1'023'228 & 1'158'010 & 13.2 \\
\hline $\begin{array}{l}\text { Developed Economies and } \\
\text { European Union }\end{array}$ & $67 ' 740$ & $64 ' 501$ & $61^{\prime} 167$ & -4.8 & $-3 ' 334$ & $126 ' 434$ & $124 ' 404$ & -1.6 \\
\hline $\begin{array}{l}\text { Central and Eastern Europe (non- } \\
\text { EU) and CIS }\end{array}$ & $30 ' 430$ & $29 ' 661$ & $23 ' 989$ & -2.5 & $-5^{\prime} 672$ & $64 ' 453$ & 70'941 & 10.1 \\
\hline East Asia & $176^{\prime} 137$ & $154 ' 511$ & $139 ' 596$ & -12.3 & $-14^{\prime} 915$ & 234 '364 & $229 ' 488$ & -2.1 \\
\hline South East Asia and the Pacific & $56^{\prime} 703$ & $61 ' 490$ & $72 ' 889$ & 8.4 & 11 '399 & $97 ' 548$ & $108 ' 909$ & 11.6 \\
\hline South Asia & $118^{\prime} 278$ & $136 ' 616$ & $148 ' 293$ & 15.5 & $11^{\prime} 677$ & $233 ' 818$ & $289^{\prime} 160$ & 23.7 \\
\hline Latin America and the Caribbean & $53 ' 738$ & $57^{\prime} 149$ & $56^{\prime} 649$ & 6.3 & -500 & $95 ' 303$ & $105^{\prime} 468$ & 10.7 \\
\hline
\end{tabular}

Source: ILO, Global Employment Trends (GET) Model, 2006 (see box 2 for more information).

Overall the youth labour force grew from 602 million to 633 million over the last decade $(5.2$ per cent) and is projected to grow from 633 million to 657 million (3.8 per cent) from 2005 to 2015. Labour force growth was highest in the Middle East and North Africa at 32.2 per cent and sub-Saharan Africa at 29.8 per cent, followed by South Asia (15.5 per cent), South East Asia and the Pacific (8.4 per cent) and Latin America and the Caribbean (6.3 per cent). Despite youth population growth, the labour force decreased in Central and Eastern Europe (non-EU) and CIS (-2.5 per cent). The final two regions - Developed Economies and European Union and East Asia - showed declining trends in both the youth labour force and youth population, although the size of the youth labour forces declined at a

\footnotetext{
${ }^{28}$ The concept of "working out of poverty" was introduced in ILO, 2003.
} 
faster pace (-4.8 per cent and -12.3 per cent, respectively) than the decline in youth population (-1.6 and -2.1 per cent, respectively). (For further discussion of the decline labour force in some regions, see section 4.)

Between 2005 and 2015 it is expected that the youth labour force will continue to grow by another 24 million. The growth will continue to be concentrated in sub-Saharan Africa, South East Asia and the Pacific, and in the Middle East and North Africa. These regions are projected to add another 24 million, 11 million and 865,000 young labour market participants, respectively. In the meantime, the size of the youth labour force will decrease in all other regions, and most considerably in East Asia.

A growing labour force can be an asset or a liability for economic development depending on the rate of growth and the employment content of growth in the country

A growing labour force can be an asset for labour markets and societies if the economy needs labour and has enough jobs to offer. However, if economic growth is not matched by growth of decent employment opportunities, labour force growth can be a threat since the competition to find jobs among the many young people entering the labour market becomes more intense. In labour markets where an excess supply of job seekers compete for vacancies, it is the young people who lack social networks and the know-how to market themselves as potential employees who will be the ones left behind to join the growing number of unemployed or discouraged youth (again, see Annex 3 for the glossary of terms). Alternatively, they will accept work under inferior conditions or move into the informal economy which offers the only possibility of earning a living. This vicious circle that results when economic growth cannot accommodate labour force growth has been observed in sub-Saharan Africa, the Middle East and North Africa, and South Asia. Conversely, a decreasing labour force can also be a challenge as can be witnessed in many developed economies, (former) transition economies and, to a certain extent, also in East Asia, where labour shortages may be starting to retard economic development. $^{29}$

The share of the labour force in the working-age population - the labour force participation rate - can be high or low depending on cultural traditions, educational attainment and the degree of inactivity (voluntary or involuntary) in a country. The trend of decreasing youth labour force participation rates has continued in recent years mainly as a result of more young people choosing to remain in education and extending their stay in education and because of growing discouragement in those economies where labour market conditions for young people are particularly bad. (For a detailed discussion on which factors impacts inactivity rates, see section 4 of this report.)

Youth labour force participation rates are decreasing in all regions

The youth labour force participation rate decreased globally from 58.9 to 54.7 per cent between 1995 and 2005, which means that today only every second young person is actively participating in labour markets around the world. (See table 2.3.) Youth labour force participation rates were highest in East Asia (67.3 per cent) and sub-Saharan Africa (65.5 per cent). The lowest rate was that of the Middle East and North Africa (40.0 per cent). Young women are increasingly participating in labour markets in the region, but the rate of increase is slowing and the female labour force participation rates remained at a much lower level than the corresponding male rate. At the same time, the labour force participation rate of men in the region dropped as more stay in the education system or become discouraged as a result of high unemployment and mismatches between labour supply and demand. Given these two offsetting trends (higher female participation and lower male participation), the Middle East and North Africa was the only region where participation rates remained stable over the last decade. The rate decreased most noticeably in East Asia, a region where labour shortages become more and more a risk for the booming countries in the region. ${ }^{30}$ Fortunately, the decreasing rate in this region is mainly the result of young people participating more, and staying longer, in education as opposed to youth falling out of the labour force due to discouragement (which has negative consequences to their future labour market integration, as discussed in section 4). Overall,

\footnotetext{
${ }^{29}$ For example, a recent ILO article found that the Russian Federation will need between 800,000 and 1.5 million migrant workers each year to compensate for its shrinking labour force and maintain economic growth. See ILO, 2006b.

${ }^{30}$ See, for example, China Labour Bulletin, 2005; and Johnson and McGregor, 2006. See, in addition, ILO, 2006a.
} 
labour force participation rates decreased during the last decade in all regions for young men, whereas for young women it decreased in all regions except the Middle East and North Africa and Latin America and the Caribbean.

Table 2.3

Youth labour force participation rates, by sex, 1995 and 2005

\begin{tabular}{|l|c|c|c|c|c|c|}
\hline & \multicolumn{2}{|c|}{ Total } & \multicolumn{3}{c|}{ Males } & \multicolumn{2}{c|}{ Females } \\
\hline & $\mathbf{1 9 9 5}$ & $\mathbf{2 0 0 5}$ & $\mathbf{1 9 9 5}$ & $\mathbf{2 0 0 5}$ & $\mathbf{1 9 9 5}$ & $\mathbf{2 0 0 5}$ \\
\hline World & 58.9 & 54.7 & 67.2 & 63.0 & 50.1 & 45.9 \\
\hline Developed Economies and European Union & 53.6 & 51.8 & 56.9 & 54.0 & 50.1 & 49.6 \\
\hline Central and Eastern Europe (non-EU) and CIS & 47.2 & 41.8 & 52.8 & 48.4 & 41.5 & 35.0 \\
\hline East Asia & 75.2 & 67.3 & 74.6 & 66.3 & 75.7 & 68.4 \\
\hline South East Asia and the Pacific & 58.1 & 56.5 & 64.5 & 64.2 & 51.6 & 48.5 \\
\hline South Asia & 50.6 & 47.2 & 68.0 & 64.2 & 31.7 & 29.1 \\
\hline Latin America and the Caribbean & 56.4 & 54.2 & 70.4 & 63.8 & 42.3 & 44.5 \\
\hline Middle East and North Africa & 40.0 & 40.0 & 56.2 & 54.3 & 23.2 & 25.1 \\
\hline Sub-Saharan Africa & 68.2 & 65.5 & 76.1 & 73.7 & 60.2 & 57.3 \\
\hline
\end{tabular}

Source: ILO, Global Employment Trends (GET) Model, 2006 (see box 2 for more information).

Labour force participation rates for young women are lower than for young men, mainly reflecting differing cultural traditions and the lack of opportunities for women to combine work and family duties not only in the developing world but also in the industrialized world. The largest gaps in the participation of young men versus women are found in South Asia (35 percentage points) and the Middle East and North Africa (29 percentage points).

The size of the labour force is also influenced by migration trends. There are no estimates on the share of young migrants among the 175 million global migrants ${ }^{31}$ around the world, but it is clear that with growing cross-border transfers of labour more and more young people will leave their homes in the hopes of finding work in other countries. Therefore, they have an impact on the labour markets in their countries as well as abroad. ${ }^{32}$ With globalization, migration will increasingly become a key economic, social and political issue, and detailed data will be needed to judge the impact of migration patterns on the labour force.

\section{$2.2 \quad$ Trends in youth employment}

Youth population growth continues to outpace employment growth

In 2005, there were 548 million employed young women and men, an increase of 6.6 million from the previous year. Compared to ten years prior, there were 20.1 million more young people working (a change of 3.8 per cent). (See table 2.4.) At the same time, the youth population grew by 135 million over the last ten years (a change of 13.2 per cent). (See table 2.2.) As discussed throughout the report, there are both positive and negative impacts associated with this discrepancy between population and employment growth. It is negative when the majority of the difference is explained by increasing numbers of unemployed youth (see discussion below) and by increased numbers of discouraged youth; it is positive when the majority of the difference is explained by more young people participating for longer periods in the educational system and if, and it's a big "if", decent employment opportunities will be available to the youth when they finally leave the education system.

The share of youth who are employed in the youth population (the youth employment-topopulation-ratio) decreased from 51.6 to 47.3 over the last ten years. The only region where the youth employment-to-population ratio increased was the Middle East and North Africa, which is noteworthy given the tremendous growth of the youth population there of over 30 per cent during this period that the labour market has had to accommodate. At the same time, the region still has the lowest youth employment-to-population ratio with 29.7 - only every third young person has a job, largely due to low, but rising female employment-to-population ratios. East Asia has the highest youth employmentto-population ratio with 62.1 but also the second biggest decrease over the last ten years of -10.6 per cent (behind an 11.8 per cent decrease in Central and Eastern Europe (non-EU) and CIS). All other

\footnotetext{
${ }^{31}$ UN, 2003.

${ }^{32}$ For a more detailed discussion on migration, see ILO, 2006c and 2004b.
} 
regions also witnessed decreases, with the exception of the Developed Economies and European Union where it stayed more or less stable over the decade.

Table 2.4

Youth employment and youth employment-to-population ratios

\begin{tabular}{|c|c|c|c|c|c|c|c|}
\hline & \multicolumn{4}{|c|}{ Youth employment ('000s) } & \multicolumn{3}{|c|}{$\begin{array}{c}\text { Youth employment-to- } \\
\text { population ratio }\end{array}$} \\
\hline & 1995 & 2004 & 2005 & $\begin{array}{c}\% \\
\text { change } \\
1995- \\
2005\end{array}$ & 1995 & 2005 & $\begin{array}{c}\% \\
\text { change } \\
1995- \\
2005\end{array}$ \\
\hline World & $527^{\prime} 886$ & $541 ' 347$ & $547 ' 976$ & 3.8 & 51.6 & 47.3 & -8.3 \\
\hline Developed Economies and European Union & $57 ' 459$ & $55^{\prime} 536$ & $56^{\prime} 020$ & -2.5 & 45.4 & 45.0 & -0.9 \\
\hline Central and Eastern Europe (non-EU) and CIS & $24 ' 469$ & 23 '932 & $23^{\prime} 762$ & -2.9 & 38.0 & 33.5 & -11.8 \\
\hline East Asia & $162 ' 988$ & $140 \prime 690$ & $142^{\prime} 435$ & -12.6 & 69.5 & 62.1 & -10.6 \\
\hline South East Asia and the Pacific & $51^{\prime} 461$ & $51^{\prime} 424$ & $51^{\prime} 763$ & 0.6 & 52.8 & 47.5 & -10.0 \\
\hline South Asia & $106^{\prime} 513$ & $120^{\prime} 836$ & $122^{\prime} 954$ & 15.4 & 45.6 & 42.5 & -6.8 \\
\hline Latin America and the Caribbean & $46^{\prime} 016$ & $47 ' 933$ & $47 ' 653$ & 3.6 & 48.3 & 45.2 & -6.4 \\
\hline Middle East and North Africa & $17^{\prime} 876$ & $24^{\prime} 243$ & $24 ' 649$ & 37.9 & 28.5 & 29.7 & 4.2 \\
\hline Sub-Saharan Africa & $61^{\prime} 105$ & $76^{\prime} 754$ & $78 ' 739$ & 28.9 & 56.2 & 53.7 & -4.4 \\
\hline
\end{tabular}

Source: ILO, Global Employment Trends (GET) Model, 2006 (see box 2 for more information).

When interpreting employment-to-population ratios, it has to be keep in mind that they most likely mean something different in the developing world where many of the jobs are in the informal economy with low wages and high levels of insecurity compared to the developed world where being employed more often means to have a good job with a decent salary and some form of social protection. Given that, in addition, people in the very poor regions have to work to survive, meaning that they have to take any work available, it becomes clear that a high youth employment-topopulation ratio, as in sub-Saharan Africa (53.7 in 2005) could be associated with a high incidence of working poverty.

\subsection{Trends in youth unemployment}

Youth unemployment continues to increase in most regions of the world

The number of young unemployed people increased by 14.8 per cent over the last ten years to the current high of 85 million in 2005. A closer look at the different regions shows an increase of 85.5 per cent in South East Asia and the Pacific, 34.2 per cent in sub-Saharan Africa, 23.0 per cent in Latin America and the Caribbean, 18.2 per cent in the Middle East and North Africa, 16.1 per cent in South Asia, slight decreases in Central and Eastern Europe (non-EU) and CIS and East Asia and a considerable decrease of 17.5 per cent in the Developed Economies and European Union. Between 2004 and 2005 the only decrease was observed in the Developed Economies and European Union. All other regions saw increases between 0.4 per cent (South East Asia and the Pacific) and 3.1 per cent (Central and Eastern Europe (non-EU) and CIS). The total number of unemployed youth has increased again over the last two years and stood at 85.3 million in 2005. (See table 2.5 and figure 2.3.)

Table 2.5

Total youth unemployment, 1995, 2004 and 2005

\begin{tabular}{|l|c|c|c|c|}
\hline & \multicolumn{3}{|c|}{ Youth unemployment ('000s) } \\
\hline & $\mathbf{1 9 9 5}$ & $\mathbf{2 0 0 4}$ & $\mathbf{2 0 0 5}$ & $\begin{array}{c}\text { \% change } \\
\mathbf{1 9 9 5 - 2 0 0 5}\end{array}$ \\
\hline World & $74^{\prime} 302$ & $84^{\prime} 546$ & $8^{\prime} 278$ & 14.8 \\
\hline Developed Economies and European Union & $10^{\prime} 281$ & $8^{\prime} 997$ & $8^{\prime} 481$ & -17.5 \\
\hline Central and Eastern Europe (non-EU) and CIS & $5^{\prime} 962$ & $5^{\prime} 724$ & $5^{\prime} 900$ & -1.0 \\
\hline East Asia & $13^{\prime} 149$ & $11^{\prime} 840$ & $12^{\prime} 076$ & -8.2 \\
\hline South East Asia and the Pacific & $5^{\prime} 242$ & $9^{\prime} 687$ & $9^{\prime} 727$ & 85.5 \\
\hline South Asia & $11^{\prime} 765$ & $13^{\prime} 561$ & $13^{\prime} 662$ & 16.1 \\
\hline Latin America and the Caribbean & $7 ' 722$ & $9^{\prime} 263$ & $9^{\prime} 495$ & 23.0 \\
\hline Middle East and North Africa & $7 ' 209$ & $8^{\prime} 380$ & $8^{\prime} 525$ & 18.2 \\
\hline Sub-Saharan Africa & $12^{\prime} 972$ & 17 '095 & $17^{\prime} 414$ & 34.2 \\
\hline
\end{tabular}


Figure 2.3

Global youth unemployment and youth unemployment rates, 1995-2005

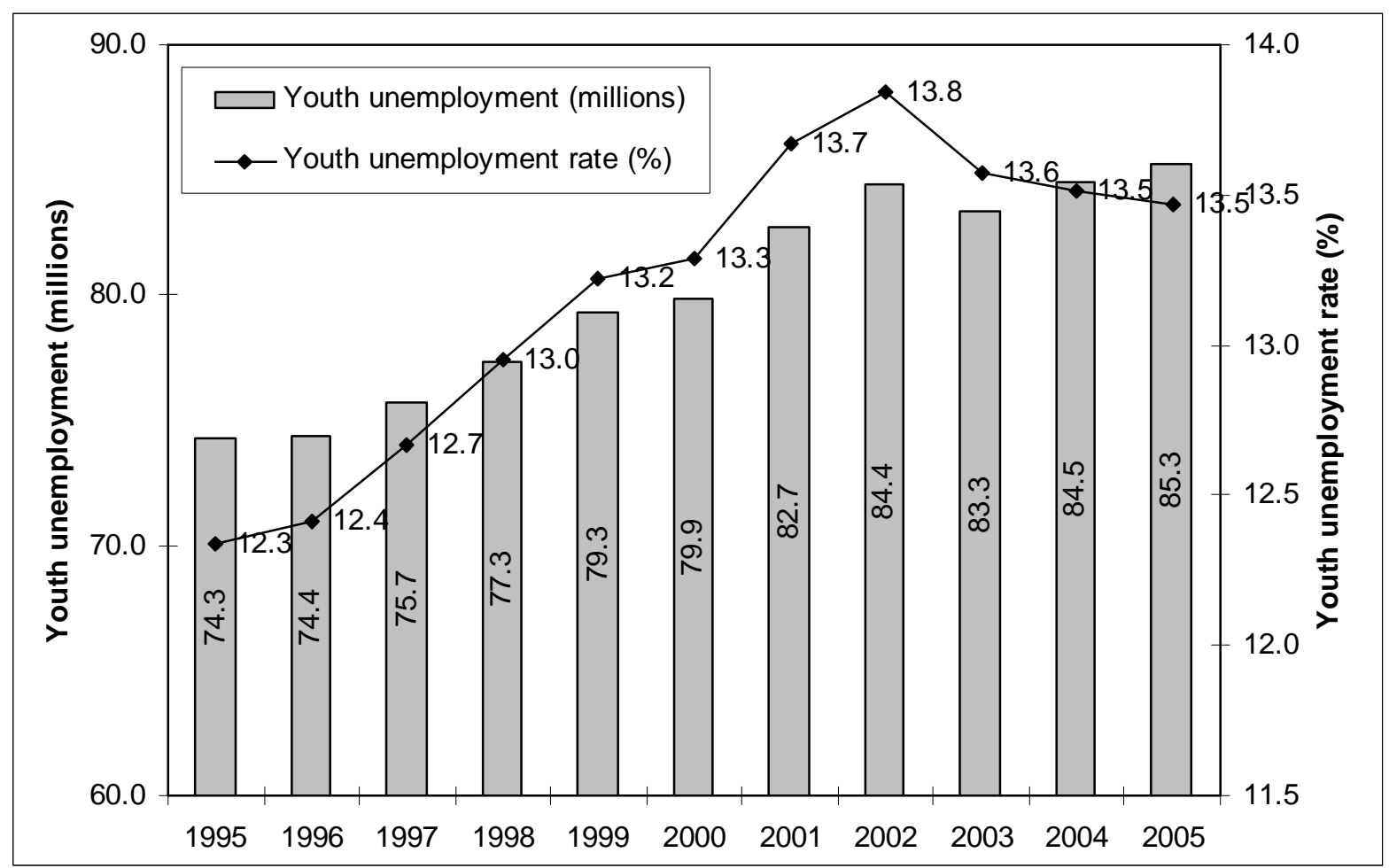

Source: ILO, Global Employment Trends (GET) Model, 2006 (see box 2 for more information).

Figure 2.4

Youth unemployment rates, by region, 1995 and 2005

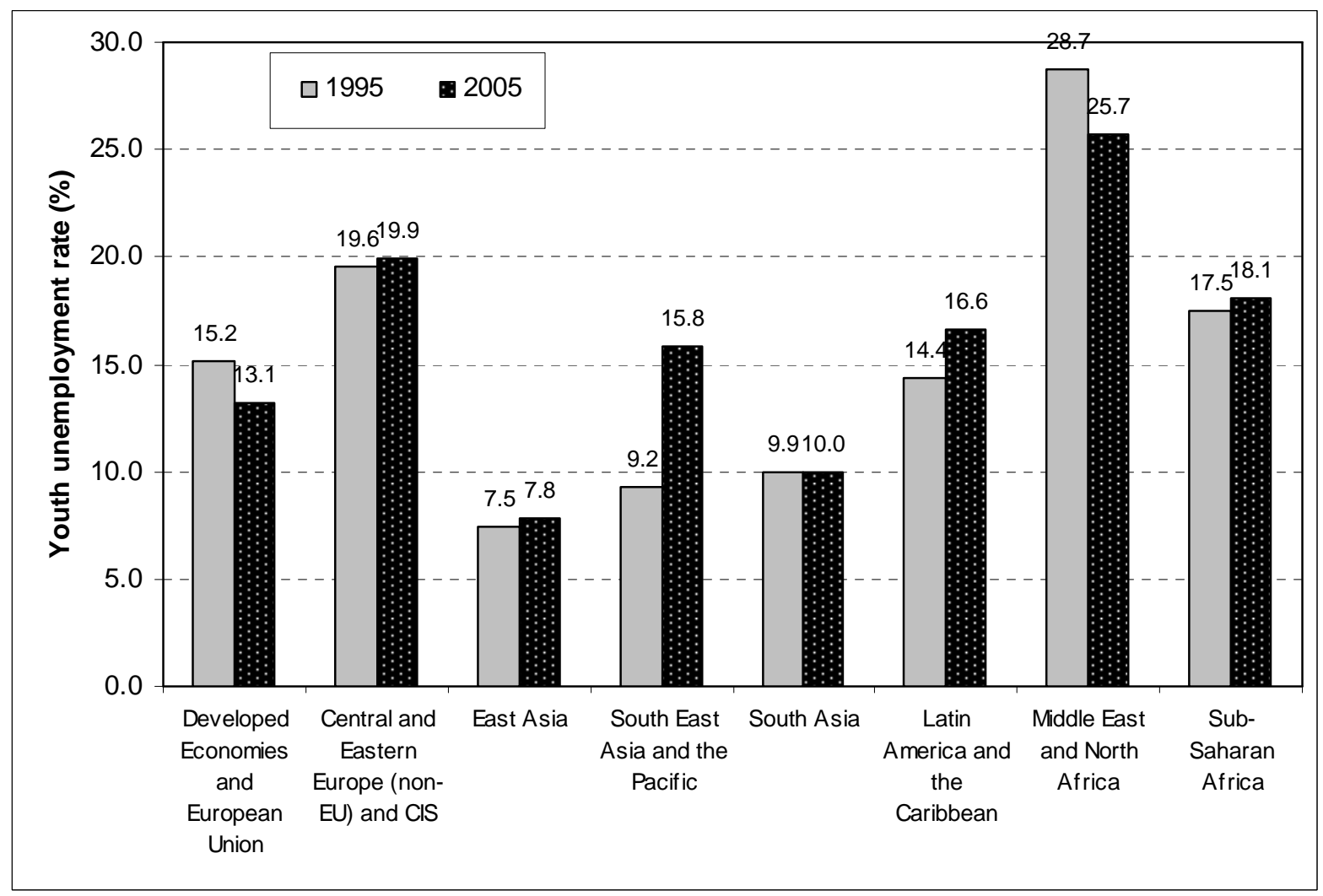

Source: ILO, Global Employment Trends (GET) Model, 2006 (see box 2 for more information). 
As seen in figures 2.3 and 2.4, worldwide the youth unemployment rate stood at 13.5 per cent in 2005 (compared to 6.4 per cent for the total unemployment rate and 4.5 per cent for the adult unemployment rate). The rate remained unchanged from 2004, but represented an increase of almost 10 per cent above the global youth unemployment rate in 1995. The highest regional youth unemployment rate can be observed in the Middle East and North Africa at 25.7 per cent. Central and Eastern Europe (non-EU) and CIS had the second highest rate in the world with 19.9 per cent. SubSaharan Africa's rate was 18.1 per cent, followed by Latin America and the Caribbean (16.6 per cent), South East Asia and the Pacific (15.8 per cent), the Developed Economies and European Union (13.1 per cent), South Asia (10 per cent) and East Asia (7.8 per cent).

The most dramatic increases in youth unemployment rates over the last ten years were in South East Asia and the Pacific where the rate increased from 9.2 to 15.8 per cent and in Latin America and the Caribbean where it increased from 14.4 to 16.6 per cent. In both cases, the reason for the increase had to do with the phases of economic crises that led to a heavy increase in unemployment in general, but even more so in youth unemployment. (It has been estimated that a 1 per cent increase in adult unemployment will be matched by 2 per cent rise in unemployment among young people. ${ }^{33}$ ) Youth unemployment rates have still not recovered from this phase. The only region that saw a considerable decrease over the last ten years was the Developed Economies and European Union. This has resulted from a combination of successful youth employment strategies and a declining number of young people in the labour force.

\section{Youth are far more likely to be unemployed than adults}

In order to shed more light on the labour market situation of young people, it is interesting to compare their unemployment rates to those of adults: youth unemployment rates ${ }^{34}$ continued to be much higher than adult rates in all regions, and in almost all countries with data available with the exception of Germany, where the ratio in 2004 was 1.2, most likely due to the widespread use of the apprenticeship system for young people, and in some African nations - Lesotho with a ratio of 1.3 in 1997 and Rwanda with a ratio of 1.4 in 1996 - where the adult and youth unemployment rates are almost equally high (or low, in the case of Rwanda). ${ }^{35}$ In most regions youth were nearly three times more likely to be unemployed than adults. The only exceptions were the Developed Economies and European Union, where youth unemployment was only 2.3 times higher than adult unemployment and, at the other end of the scale, South East Asia and the Pacific, where youth unemployment was more than 5 times higher than adult unemployment. (See table 2.6.)

Table 2.6

Ratio of youth-to-adult unemployment rates, 1995 and 2005

\begin{tabular}{|c|c|c|}
\hline & \multicolumn{2}{|c|}{$\begin{array}{l}\text { Ratio of youth-to-adult } \\
\text { unemployment rate }\end{array}$} \\
\hline & 1995 & 2005 \\
\hline World & 2.8 & 3.0 \\
\hline Developed Economies and European Union & 2.3 & 2.3 \\
\hline Central and Eastern Europe (non-EU) and CIS & 2.6 & 2.6 \\
\hline East Asia & 2.9 & 2.8 \\
\hline South East Asia and the Pacific & 4.7 & 5.1 \\
\hline South Asia & 3.6 & 2.8 \\
\hline Latin America and the Caribbean & 2.7 & 2.8 \\
\hline Middle East and North Africa & 3.0 & 3.1 \\
\hline Sub-Saharan Africa & 3.3 & 3.0 \\
\hline
\end{tabular}

\footnotetext{
${ }^{33} \mathrm{UN}, 2004$, p. 62.

${ }^{34}$ Unemployment rates, as the most visible and obvious indicator for judging the situation of young people in labour markets, was chosen as the indicator to monitor the UN Millennium Goal to "develop and implement strategies for decent and productive work for youth". As discussed in various publications the use of this indicator alone is not entirely satisfactory since it is only through the interpretation of a set of indicators that a holistic view of young people's labour market performance can be judged. Given the definition of unemployment (see Annex 3) - a person who does not have a job but is actively looking for one - a high rate indicates that there are many people actively looking for work. It does not say anything about those who have given up on the job search (discouraged people) or people who are outside the labour force for other reasons.

${ }^{35}$ Country level ratios are available from ILO, 2005a, table 9.
} 


\section{Box 2.1 \\ Why are youth unemployment rates higher than adult unemployment rates?}

The data shown in table 2.6 confirm that youth unemployment rates are between 2 and 6 times higher than adult unemployment rates depending on the region, leading us to the important questions: why are youth unemployment rates so much higher than adult rates? There are many likely explanations:

- The last-in, first-out explanation. Youth are more vulnerable than adults in difficult economic times. They are likely to have less work experience than adults. Assuming that employers seek employees with past experience (and as discussed in section 5, this is the case), the youth who is entering the labour force for the first time will be at a disadvantage and have a harder time finding employment vis-à-vis an adult with a longer history of work experience. In times of surplus labour competing for a limited amount of jobs, the youth will be the "last in". Similarly, because a young worker is likely to have less tenure than an adult worker, less company funds invested in them for training purposes and to have a temporary contract, it will be considered cheaper to let the younger worker go in times of economic downturns. Thus, young workers will be the "first out".

- The lack of job search expertise explanation. A young person often lacks both labour market information and job search experience. In many developing countries, it is only through informal placement methods typically through family and friends - that a young person finds work. Beyond the word of mouth approach through families and friends, they simply might not know how and where to look for work. Adults, on the other hand, might have the possibility of finding future work through references from previous employers or colleagues and are more likely to know the "right" people.

- The "shopping around" explanation. Another possibility is that youth might take longer to "shop around" for the right job, meaning they might wait longer to find work that suits their requirements. This, however, implies that a support structure, such as the family, exists to economically support them while they search for work. In low-income countries, this support structure does not exist for the majority of young people and as a result, a young person simply cannot afford to be unemployed and is likely to take whatever work becomes available, regardless of working conditions or whether or not the job fits his/her education or skills-base.

- The lack of mobility explanation. Young people just starting out in the labour force are unlikely to have the financial resources to re-locate, nationally or internationally, in pursuit of work. Because many will continue to depend on household incomes, their job search threshold will be limited to the nearby vicinity of the family home.

- The measurement explanation. As discussed in section 4 of this report, inactivity among young people is increasing. Conversely, the labour force of youth, and thus the denominator of the youth unemployment rate calculation, is shrinking in many parts of the world as more young people are enrolled in education or staying in the education system for longer periods of time or dropping out of the labour force as discouraged workers. This means that if from year X to year Y, the youth labour force in year $\mathrm{Y}$ is less than that of year $X$ (and assuming the absolute total of unemployed youth remained constant), the youth unemployment rate (as number of youth unemployed/youth labour force) will be higher in year $\mathrm{Y}$ than in year X. There has not been a similar shrinkage of the adult labour force, which means that the gap between the youth and the adult unemployment rates would grow.

The explanations given above - and there are likely to be even more - are a mixture of demand-side causes ("last in-first out" particularly) and supply-side causes ("shopping around", etc.). None of the explanations is likely to explain in full the difference between youth and adult unemployment rates. What is most likely is that the different factors work together - and do not underestimate the influence of the shrinking youth labour force on the measurement - to result in the proportion of unemployed youth in the youth labour force being significantly higher than the proportion of unemployed adults in the adult labour force.

An additional way to look at unemployment that helps to complete the picture is the youth unemployment share in total unemployment. This share was 43.7 per cent in 2005 meaning that almost every second unemployed person in the world is between the ages of 15 and 24 years. (See table 2.7.) This share has not changed considerably over the last ten years. It is a particularly troublesome indicator as youth only make up 25 per cent of the total working-age population. The share of youth unemployed among total unemployed was highest in sub-Saharan Africa and South East Asia and the Pacific, where six out of ten unemployed people were youth in 2005. The lowest share was in the Developed Economies and European Union at only 26.2 per cent. 
Table 2.7

Youth share in total unemployed and youth share in total working-age population, 1995 and 2005

\begin{tabular}{|l|c|c|c|c|}
\hline & \multicolumn{2}{|c|}{$\begin{array}{c}\text { Youth share of } \\
\text { total unemployed } \\
(\%)\end{array}$} & $\begin{array}{c}\text { Youth share in total } \\
\text { working-age } \\
\text { population (\%) }\end{array}$ \\
\hline & $\mathbf{1 9 9 5}$ & $\mathbf{2 0 0 5}$ & $\mathbf{1 9 9 5}$ & $\mathbf{2 0 0 5}$ \\
\hline World & 46.1 & 43.7 & 26.3 & 25.0 \\
\hline Developed Economies and European Union & 29.7 & 26.2 & 17.2 & 15.7 \\
\hline Central and Eastern Europe (non-EU) and CIS & 34.2 & 32.9 & 21.6 & 22.1 \\
\hline East Asia & 47.2 & 39.5 & 24.6 & 20.9 \\
\hline South East Asia and the Pacific & 61.6 & 58.8 & 30.7 & 27.5 \\
\hline South Asia & 53.8 & 45.5 & 30.0 & 29.3 \\
\hline Latin America and the Caribbean & 49.5 & 44.7 & 30.0 & 26.9 \\
\hline Middle East and North Africa & 51.7 & 49.7 & 33.5 & 32.6 \\
\hline Sub-Saharan Africa & 61.1 & 59.5 & 35.7 & 36.9 \\
\hline
\end{tabular}

Box 2.2

Inequalities in youth labour markets

As has been discussed in detail in the Global Employment Trends for Youth 2004 version, young people as a group are not homogenous; there are certain subgroups that, in addition to being young, face other disadvantages that make it even harder for them to find a decent job. The data needed to find out which subgroups suffer most are still mainly available only for OECD countries, but anecdotal evidence shows that the following trends observed in these countries are replicated in the developing world:

- In general, young women have even more difficulties finding work than young men. Even though there are countries and regions where unemployment is lower for young women than for young men, this often only means that women do not even try to find a job but leave the labour market, discouraged, altogether. When they do find a job it is often lower paid and in the informal economy, in unprotected low-skill jobs. (For more information on labour market difficulties specific to women, see Elder and Schmidt, 2004. See, also, ILO, 2004a.)

- The unemployment rate tends to fall with age in most countries where data is available. The very young among the youth (aged 15 to 19) - typically those with the least education and certainly those with the least experience - have the greatest difficulties finding work, which makes it more difficult for them to gain the experience sought by the employers.

- Education can be a boon or a hindrance, depending on the economic conditions of the country. In OECD countries, unemployment is higher among less educated young people. Higher education generally not only reduces the risk of unemployment, but also increases the chances of obtaining full-time employment with a long-term contract. In developing countries, however, where the supply of highly educated youth has outpaced the supply of (typically service sector) jobs to accommodate them, unemployment tends to increase among better educated young people. This is particularly true in the Middle East and North Africa. A logical consequence is often that the well-educated young people leave their countries resulting in a loss to the country of the investment placed in them and a brain drain.

- Almost every country for which data are available shows higher unemployment among ethnic minorities. This is not always the result of lower education levels, but of discrimination by employers in the labour markets.

- The poorer the parents the more likely it is that the children will be unemployed. Data for a few developed economies show this correlation.

\subsection{Other labour market indicators for youth}

More information on the quality of work is needed

As discussed in the Global Employment Trends for Youth 2004 edition, the traditional indicators discussed above only show the tip of the iceberg concerning young people's performance in labour markets. The most disturbing trend perhaps is that, among young people who do manage to find work, working conditions tend to be below standard. Young workers often find themselves working 
long hours, on short-term and/or informal contracts, with low pay, little or no social protection, minimal training and no voice at work. ${ }^{36}$

Obtaining an accurate picture of overall conditions of work is hampered by the paucity of data available, especially in a form that enables comparisons among countries. As discussed in section 5, an occasional survey aimed specifically at capturing more of the qualitative characteristics of youth labour market situations, such as the ILO school-to-work transition surveys, will help shed more light on the situation of young people's working conditions. Some evidence is given in section 5 of the likelihood that young people rarely work with fixed term contracts, if they have any contract at all, and that youth wages and job satisfaction are typically low. More country level data on working conditions for young people is needed to widen our knowledge base so that strategies can be developed for ensuring decent and productive work opportunities for young men and women.

\subsection{Summary}

Figure 2.5 summarizes the situation of young people in comparison to adults, comparing the status within labour markets (employed, unemployed or inactive). It shows clearly that within the regions youth have higher shares of unemployment and inactivity and lower employment shares compared to adults. Regarding inactivity, the situation is less favourable in Central and Eastern Europe (non-EU) and CIS, South Asia and the Middle East and North Africa. In all three regions this cannot be fully explained by high participation in education because many young people in these regions are neither in school nor in education, as will be discussed in section 4. The difference in unemployment shares between adults and young people is particularly high in South East Asia and the Pacific and sub-Saharan Africa. Finally, regarding employment, youth are most disadvantaged again in the regions of South East Asia and the Pacific, the Middle East and North Africa and Central and Eastern Europe (non-EU) and CIS.

Figure 2.5

Distribution of the youth and adult populations by activity status, 2005

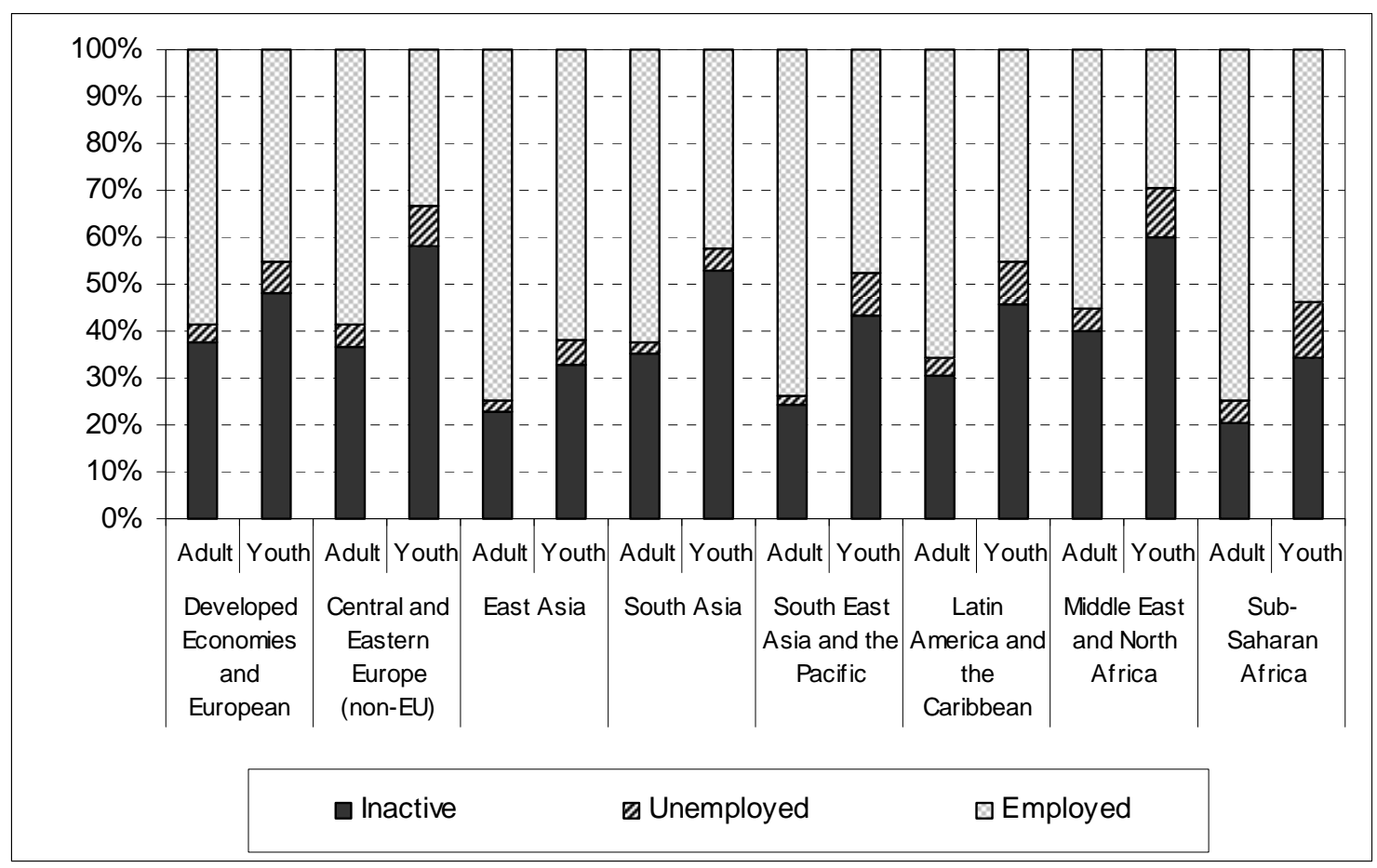

Source: ILO, Global Employment Trends (GET) Model, 2006 (see box 2 for more information).

\footnotetext{
${ }^{36}$ Some country level studies and cross-country studies exist which look in detail at issues such as the wages, hours of work, etc. of young people. See the website of the ILO Youth Employment Programme for a bibliography of country or regional studies of youth issues at www.ilo.org/public/english/employment/yett/publ.htm. Temporary work has also been quantified but only for a few European Union countries. EUROSTAT data showed that in the first quarter 2005, 40 per cent of young workers in the European Union were employed under temporary contracts (compared to 11 per cent of prime-age workers (aged 25 to 54 years). See EUROSTAT, 2005.
} 


\title{
3. Trends in youth poverty and working poverty
}

\subsection{Measuring youth poverty}

\author{
Youth poverty data are strongly needed but not available
}

The UN World Youth Report 2003 was one of the first publications that attempted to provide quantitative estimates of young people living in poverty around the world. These estimates were updated in the UN World Youth Report 2005. ${ }^{37}$ The UN estimated that 160 million young people were undernourished (a proxy for living in poverty), 208.6 million were surviving on less than a US\$1 a day, and 515.1 million were surviving on less than US\$2 a day. (See table 3.1.)

Table 3.1

Poverty estimates of undernourished young people (1999-2001) and young people living on less than US $\$ 1$ a day and US $\$ 2$ a day, by region, 2002

\begin{tabular}{|l|c|c|c|}
\hline & $\begin{array}{c}\text { Undernourished } \\
\text { young people } \\
\text { ('000s) }\end{array}$ & $\begin{array}{c}\text { Youth living on } \\
\text { less than US\$1 a } \\
\text { day ('000s) }\end{array}$ & $\begin{array}{c}\text { Youth living on } \\
\text { less than US\$2 a } \\
\text { day ('000s) }\end{array}$ \\
\hline South Asia & 57.8 & 84.1 & 206.1 \\
\hline East Asia \& Pacific & 38.6 & 46.5 & 150.5 \\
\hline Sub-Saharan Africa & 39.9 & 60.7 & 102.1 \\
\hline Latin American \& Caribbean & 10.8 & 11.1 & 27.2 \\
\hline Europe \& Central Asia & 5.8 & 4.1 & 18.2 \\
\hline Middle East \& North Africa & 7.1 & 2.0 & 12.1 \\
\hline Total* & 160.1 & 208.6 & 515.1 \\
\hline
\end{tabular}

* The total does not reflect exactly the sum total of the regions due to rounding.

Note: The UN regions do not coincide exactly with the regions utilized in this report (see Annex 2 for the Global Employment Trends regional groupings.

Source: UN, 2005, tables 2.2 and 2.3.

Such a variation in the poverty estimates hints at the two challenges of quantifying youth poverty, which so far have not been overcome: 1) the challenge of defining the term "poverty" (see box 3.1); and 2) the non-availability of country level data. There is a significant lack of information on young people who live in poverty. Estimates on poverty are typically derived from household surveys and are estimated at the household level. A household is classified as poor or non-poor based on the cumulative income of the household members. Unequal distribution within a household is not considered and household members are not asked separately about their income or expenditure. This is the main reason why poverty data disaggregated by age, sex or any other demographic criteria are unavailable.

Is there a genuine need for disaggregating data into the poor who are young and poor who are adults? This report argues that there is a strong necessity based on the followings reasons:

1) Young people are frequently overlooked in national poverty reduction strategies and investing in youth is not often seen as essential to promoting sustainable development. Unless more is known about the specific situation of young people in poverty and about the nature and extent of their vulnerabilities it is likely that they will not be given the attention they deserve in national poverty reduction strategies.

2) Young people often face a different type of poverty compared to adults. Existing forms of data collection concentrate on finding out about population groups trapped in chronic poverty while young people are more likely to be experiencing a more dynamic form of poverty. One researcher found that "The transition from childhood to adulthood involves confronting and overcoming a number of uncertainties. Moreover, young people potentially face a large number of changes at the same time, thus compounding their difficulties. These obstacles are encountered in relation to work, living arrangements and personal relationships. Identifying the uncertain outcomes young people or subgroups of young people are facing is the first step in devising ways to improve levels of social protection. ${ }^{\prime 38}$ Therefore, recognizing that youth in poverty face unique obstacles implies

\footnotetext{
${ }^{37}$ UN, 2005. See especially, Part I: Youth in The Global Economy: Young people living in poverty. The UN World Youth Report 2003 is available on website: www.un.org/esa/socdev/unyin/wyr03.htm.

${ }^{38}$ Curtain, 2004.
} 
that poverty reduction strategies for youth might necessitate different approaches than those for adults.

If one accepts that poverty is a multi-faceted and changeable state, then collecting data on poverty becomes a more complex task that requires going beyond the usual aggregate cross-sectional data to longitudinal collection of information about the same individuals or same group's experiences of poverty.

\section{Box 3.1 \\ What is poverty?}

Measuring poverty is not an easy task. First one has to work through numerous questions such as those that follow and then decide upon the ultimate definition of poverty to be measured:

- Is poverty merely a lack of income or should it include other dimensions related to human survival, such as access to good sanitation, health care and education opportunities?

- If poverty is defined as low income, what is the best way of measuring the income of individuals and households?

- If poverty is defined more broadly, what measures are appropriate to capture access to needed services?

- In relation to the poverty measures used, should the reference point be to some absolute level or is poverty a relative concept that needs to be related to the standard of living of the society in which the poor live?

It is now widely accepted that poverty entails multiple dimensions of deprivation and therefore refers to more than lack of income. The UN Millennium Development Goals adopted a broader view and therefore cover numerous dimensions of poverty (hunger, health and income). Amartya Sen was one of the first economists who argued that poverty is best understood as various forms of "unfreedom" that prevent people from realizing and enlarging their capabilities. This conception of poverty takes into consideration both civil and political liberties and economic and social rights as primary goals of development and the principal means of progress. Sen's concept of poverty also acknowledges that personal experiences of poverty can change according to circumstances. Such a dynamic view of poverty is often more applicable to young people due to the obstacles most of them face in seeking to achieve adult status.

Sources: Curtain, 2004; Sen, 2000.

Given this lack of age-disaggregated data and the difficulties of a defining poverty, how did the UN calculate the headcount of young people in extreme poverty? They used a simple but logical method of taking the absolute number of poor people (the World Bank estimates of persons living on less than US $\$ 1$ a day) as the basis. They then calculated the proportion of people in a country below the poverty line and applied this proportion to the population of the youth (15 to 24) age group to generate the number of young people below the poverty line. For countries for which there are no poverty measures, estimates of young people in poverty were made by matching them with the closest country - in terms of several indicators - with an available poverty measure. ${ }^{39}$

This methodology which was first applied in the 2003 UN report was again used for the 2005 report even though the authors caution that the primary assumption behind the model - that the distribution of poverty among young people follows the same pattern as the distribution among the total population - has not yet been proven. The detailed results given by the UN youth poverty estimates are shown in table 3.1. According to these estimates one in five young people in the world (19.3 per cent of the world's youth population of 1.1 billion) are living in extreme poverty. Using the US\$2 a day measure, nearly half of all young people can be categorized as living in poverty (47.6 per cent of the youth population).

\subsection{Going beyond youth poverty to youth working poverty}

Youth working poverty is a key challenge for development

Many young people in the world experience poverty despite the fact that they are working; these are the youth "working poor" (see box 3.2). A primary cause of their inability to escape from poverty is the type of work they do and the inability to find more decent and productive work. The

\footnotetext{
${ }^{39}$ For details see Curtain, 2004, and UN, 2003 and 2005.
} 
poor are most likely to be found working in jobs under poor conditions with long hours, low wages, lack of contract (and thus security), and often in the informal economy. Similar to absolute poverty among youth, there is very little published evidence to show the incidence of working poverty for youth. At the same time it is an undeniable tenet - and now one that is recognized within the $\mathrm{UN}^{40}$ as well as other international organizations and governments - that it is only through decent employment opportunities that young people get the chance to work themselves out of poverty. Youth employment is therefore an integral part of the UN Millennium Declaration, both as an important target in its own right in the MDG 8 and as a key contribution to meeting other MDGs. ${ }^{41}$

\section{Box 3.2 \\ What is working poverty?}

Working long hours for low wages under poor conditions and with no social security or any voice is the exact opposite of what the ILO would call "decent work". Quantifying the extent of non-decent work in order to show the dimension of the problem remains one of the ILO's greatest challenges. The ILO developed the concept of working poverty as a means of quantifying the income-related aspects of decent work, under the assumption that people who work but do not earn enough to lift themselves and their families above the US\$1 or 2 a day poverty line are not engaged in decent and productive work. There is a strong possibility that people who constitute the working poor work in the informal economy (whereas the reverse is not necessarily the case, i.e. people who work in the informal economy are not necessarily working poor). For this reason, in the absence of better data, the estimate of working poor can also be interpreted as a rough approximation of people who work in the informal economy with very low earnings.

It is important to note that, by definition, a person is counted as working poor only if that person is unable to lift himself or herself and his or her family above the poverty threshold. This means that someone who earns only 50 cents a day would not be considered as working poor if another member of their household earns enough to make the cumulative household income more than US $\$ 1$ a day per head. Conversely, somebody might earn as much as, for example, US\$5 a day but with a family comprising, say, 10 members ( 9 of them not working) each member would be living on less than US $\$ 1$ a day. Such a person would be counted as working poor. The ILO recognizes that there are disadvantages to relying on household level income rather than individual income such as earnings from work - for example, if income is not equitably distributed within a household, certain household members could be living in conditions of poverty while others do not. However, in the absence of individual level income data over time, the household income serves as the only available approximation of individual poverty. In addition, given that in the developing world, income tends to be pooled within a household, the ILO feels that the methodology used to determine the working poor is a viable one. A final advantage to the ILO methodology is that by including the whole household in the concept of working poverty, one ensures that a rich young person in the developing world who has just started working life and does so without remuneration, in order to gain work experience, is not considered as working poor.

Source: ILO, 2005b, box 1.1 .

Given the lack of data and the continued demand for more detailed information about young people who work but still live in poverty, a careful methodology was used in this report to generate a rough estimate of the size of the young working poor. As there are no poverty data available by age (see discussion above), the only method at this time to produce such an estimate was to combine employment data from the ILO Global Employment Trends Model with the overall working poor data from the ILO Working Poverty Model (see box 2 for details). Both models have been verified by a large group of specialists and have been used for an extended period of time in various ILO reports. Based on the regional estimates generated from the models, the estimation methodology used to approximate the number of young people in working poverty was carried out as follows:

\footnotetext{
${ }^{40}$ ECOSOC High-level Segment: Ministerial Declaration, 5 July 2006, E/2006/L.8.

${ }^{41}$ Five of the Goals may be identified as referring directly to youth because they relate to issues primarily associated with young people, including educational attainment, gender balance in education, improved maternal health, combating HIV/AIDS and other diseases such as malaria and tuberculosis, and decent employment opportunities for youth. In addition greater investment in improving adolescent health and education will not only reduce poverty, but also bring countries closer to achieving the targets for two other MDGs. Overall improvements in adolescent health will reduce the incidence of highrisk pregnancies among undernourished teenagers and thereby contribute significantly to reducing child mortality, the objective of Goal 4. Higher educational levels and improved nutrition among young mothers will help reduce the prevalence of underweight children below five years of age (one of the indicators for Goal 1), which will contribute substantially to the eradication of hunger, as called for in Goal 1 (UN, 2005, p. 25).
} 
1. The youth share in total employment was calculated.

2. The youth share in total labour force was calculated.

3. As it is not known whether poor people are more likely to imitate the overall employment behaviour of the total population, in which case the employment share would be applied to the poverty figures, or are more likely to imitate the overall labour force behaviour of the population, in which case the labour force share would be applied to the poverty figures, the more cautious approach was taken by calculating the average of the result of steps 1 and 2. ${ }^{42}$

4. The average of the youth share in total employment and the youth share in total labour force was applied to the total regional working poor (US\$1 and US\$2 a day levels) to get a total number of youth working poor living below these levels.

5. The result of step 4 was divided by total youth employment to get a youth working poverty rate.

We are, of course, aware of difficulties with this estimation technique that stem from the strong assumption made in step 4, namely that youth have the same poverty pattern as the overall population. One valid argument against the premise is that there are specificities of the age group that would warrant their receipt of lower pay. Numerous countries, for example, have implemented minimum wages for young people that are lower than those of adults. ${ }^{43}$ However, from the point of view of this estimation methodology, whether or not youth receive lower pay than other groups is irrelevant since the absolute poverty measure utilized is one based on cumulative household income. If an adult lives in a poor household, s/he is counted as poor; the same as a young person living in a poor household would be. If, however, adults are likely to head up smaller households with fewer breadwinners, then it is true that poverty might be slightly skewed toward adults. Nonetheless, in the absence of better information, the estimation technique applied here serves as a best currently available estimate of youth working poor.

As a precaution, to make sure that the estimates are realistic, we made the same calculations using the model-generated country level data (technique 2) and also applying aggregate employment and labour force shares (average) to the UN youth poverty estimates in table 3.1 (technique 3 ) to crosscheck. The global and regional aggregates of youth working poor generated through each technique are similar enough to add confidence to the numbers ultimately shown in table 3.2. We also checked the results as best we could against the anecdotal evidence we have from countries and experts on each of the regions. If anything, the results are more likely to give an underestimation than an overestimation of the problem of working poverty among youth for the following reasons:

1. As was stated in the UN report and other publications, it is likely that the share of poor among young people is even higher than among the overall population, given young people's special vulnerabilities.

2. There are strong reasons to believe, as mentioned above, that among young poor people the employment share is closer to the labour force share of the total population, meaning less unemployment exists than among the total population as almost all poor persons in the youth labour force have to work to survive - especially those who have just left their home or are about to build up their own family.

\footnotetext{
${ }^{42}$ Research done on this question has so far brought mixed results. In some countries it seems that the poor have similar employment shares meaning that if in the total working age population 10 per cent have a job, it is the same among the poor in this country. In other countries it was found that the share of people working is much higher among the poor, sometimes even higher than the labour force share in working age population. Thereby taking the average is the best guess possible until there is more data available. This is also the approach taken in the ILO Working Poverty Model (see box 2 for more information).

${ }^{43}$ For more information on countries that set lower minimum wages for young workers and the arguments for doing so, see Eyraud and Saget, 2005, pp. 48-62.
} 
Table 3.2

US $\$ 1$ and US\$2 a day working poverty among youth, total numbers and youth working poverty rates*

\begin{tabular}{|c|c|c|c|c|c|c|}
\hline & \multicolumn{3}{|c|}{$\begin{array}{l}\text { Youth US\$1 a day working } \\
\text { poor ('000s) }\end{array}$} & \multicolumn{3}{|c|}{$\begin{array}{l}\text { Youth US\$2 a day working } \\
\text { poor ('000s) }\end{array}$} \\
\hline & 1995 & 2004 & 2005 & 1995 & 2004 & 2005 \\
\hline World & $155^{\prime} 894$ & $127 ' 350$ & $124 ' 534$ & $329 ' 678$ & $309^{\prime} 178$ & $308^{\prime} 450$ \\
\hline Central and Eastern Europe (non-EU) and CIS & 1'887 & 821 & 679 & 8'494 & $4^{\prime} 169$ & 3'481 \\
\hline East Asia & $40^{\prime} 771$ & $20 ' 844$ & $19^{\prime} 115$ & $106^{\prime} 150$ & $69 ' 305$ & $67 ' 121$ \\
\hline South East Asia and the Pacific & 9'977 & $66^{\prime} 753$ & $66^{\prime} 605$ & $35^{\prime} 814$ & $31 ' 901$ & $31 ' 592$ \\
\hline South Asia & $60 ' 266$ & $46 ' 923$ & $45^{\prime} 535$ & $99^{\prime} 761$ & $109 ' 962$ & $111 ' 369$ \\
\hline Latin America and the Caribbean & $6^{\prime} 311$ & $6^{\prime} 620$ & 6'349 & $17^{\prime} 903$ & $17^{\prime} 080$ & $16^{\prime} 671$ \\
\hline Middle East and North Africa & 648 & 841 & 839 & $8 ' 332$ & $9^{\prime} 672$ & $9^{\prime} 660$ \\
\hline \multirow[t]{3}{*}{ Sub-Saharan Africa } & $36 ' 034$ & $44^{\prime} 548$ & $45^{\prime} 413$ & $53 ' 226$ & $67^{\prime} 090$ & $68 ' 557$ \\
\hline & \multicolumn{3}{|c|}{$\begin{array}{c}\text { Youth US\$1 a day working } \\
\text { poverty rate }(\%)\end{array}$} & \multicolumn{3}{|c|}{$\begin{array}{c}\text { Youth US\$2a day working } \\
\text { poverty rate (\%) }\end{array}$} \\
\hline & 1995 & 2004 & 2005 & 1995 & 2004 & 2005 \\
\hline World & 29.5 & 23.5 & 22.7 & 62.5 & 57.1 & 56.3 \\
\hline Central and Eastern Europe (non-EU) and CIS & 7.7 & 3.4 & 2.9 & 34.7 & 17.4 & 14.6 \\
\hline East Asia & 25.0 & 14.8 & 13.4 & 65.1 & 49.3 & 47.1 \\
\hline South East Asia and the Pacific & 19.4 & 13.1 & 12.8 & 69.6 & 62.0 & 61.0 \\
\hline South Asia & 56.6 & 38.8 & 37.0 & 93.7 & 91.0 & 90.6 \\
\hline Latin America and the Caribbean & 13.7 & 13.8 & 13.3 & 38.9 & 35.6 & 35.0 \\
\hline Middle East and North Africa & 3.6 & 3.5 & 3.4 & 46.6 & 39.9 & 39.2 \\
\hline Sub-Saharan Africa & 59.0 & 58.0 & 57.7 & 87.1 & 87.4 & 87.1 \\
\hline
\end{tabular}

* Youth working poverty rate $=$ share of young working poor in total youth employment

Source: Authors' calculations based on the results of the ILO, Global Employment Trends Model, 2006 and the ILO, Working Poverty Model, 2006 (see box 2 for more information).

The results show that approximately 125 million young people or one in five who are working could be counted as US\$1 a day working poor. In other words, every fifth young person in the world works but remains in a household living in extreme poverty. This is less than ten years ago, but this "success" has to be interpreted carefully as, once again, part of the result has to do with the fact both the labour force participation rates and employment-to-population ratios of young people are shrinking. In addition, it is very likely that some young people simply moved just above the threshold of US $\$ 1$ a day and now belong to the group of US\$2 a day working poor.

The situation is most alarming for sub-Saharan Africa, the only region that has seen a sharp and continuous increase of the total number of youth working poor at the US $\$ 1$ a day level (from 36 million to 45 million between 1995 and 2005). Even though the working poverty rate has decreased slightly over the last ten years - which is mostly the result of higher youth shares in the working-age population as a result of demographic shifts - still almost six out of ten young people who are working are still living in extreme poverty. Extreme working poverty is also still a big problem in South Asia, where almost four out of ten young people work but remain poor. But at least the long-term trend has shown some improvement in the region; ten years ago, almost six out of ten young working people were US\$1 a day working poor, which was almost as much as in sub-Saharan Africa.

Youth US\$2 a day working poverty has also decreased over the last ten years in the world as a whole (from 330 million to 309 million), but still every second young person with a job has to survive with his family on less than US $\$ 2$ a day per family member. The decrease has been most considerable in Central and Eastern Europe (non-EU) and CIS and in East Asia. In South Asia and sub-Saharan Africa only one out of ten young people earn enough to lift themselves together with their families above the threshold of US\$2 a day.

\subsection{The need to know more about poverty}

Poverty and employment are strongly linked. As long as poverty remains a major barrier to education, children from poor households will not get the education needed to escape the poverty trap and they will continue to struggle in work that is less productive and lack the most basic elements of decent employment. They will in turn fail to lift themselves and their families out of poverty (assuming demand is higher for better educated youth). Therefore, if successful strategies are to be developed that aim to help young people escape from poverty then more information is needed about 
youth poverty in general and also about the labour market characteristics of young people in poverty. Without better information, it is likely that - as in the past - young people will be frequently overlooked in national poverty reduction strategies. It will require a careful assessment to show, definitively, that investing in youth is an essential part in the promotion of sustainable development.

\section{Young girls and young refugees have the lowest chances to escape poverty}

Within the group of young people some subgroups have an even higher risk of remaining in poverty, whether they work or not. Two particularly disadvantaged groups are young girls and refugees.

When poor parents need to make a choice about which of their children should receive an education, girls tend to be excluded first. The literacy gap between young men and young women appears to be widening in Africa and Asia; the greatest gender inequalities are found in North Africa and Western Asia, where educationallydeprived girls outnumber the corresponding groups of boys by almost three to one. Countries in East Asia and the Pacific have come close to achieving gender parity in access to education, while in Latin America and the Caribbean there appears to be a slight bias against boys. (UN, 2005, p. 14.) Without an education chances of getting a decent job are almost zero. That is why young girls in the developing world have little option but to get married which, given their poor family background, is most likely just a move from one poor household to the next. UNDP estimates that 70 per cent of the 1.3 billion people living in extreme poverty and suffering from hunger are women. (UNDP, 1995.) There is no reason to think that this share would be lower among young women.

Another group of young people with little prospect of a decent future life are young refugees, even if before becoming a refugee they were not poor. In general, about 35 out of 100 refugees are young people between the ages of 12 and 24. These are the people outside of the "development mainstream", meaning that the governments and donor development projects generally do not reach them. Very little is known about their chances to escape poverty but, as they have to start from nothing, it is very likely that they become trapped in the poverty cycle. (See UN, 2006.) 


\title{
4. Explaining youth inactivity and labour market vulnerability
}

\subsection{Explaining youth inactivity}

\author{
Most young people today enter the labour market
} at a later age than their parents

According to the international standards for classification of the economically active population, the young persons who are neither employed nor unemployed (the sum of which equal the labour force) comprise the residual group of young persons who are not in the labour force, or, equivalently, (currently) economically inactive youth. ${ }^{44}$ Given that, voluntary or not, more young persons today are postponing their entry into the labour market until they are beyond the age of 25 , after which they no longer qualify as "youth" according to the international standard, youth inactivity rates have increased. As a matter of fact all regions showed an increase in the youth inactivity rate over the ten year period (see table 4.1).

Globally, the youth inactivity rate rose from 41.1 to 45.3 per cent between 1995 and 2005 . Youth inactivity continues to be highest in the Middle East and North Africa and in South Asia, which mimics the trend of the overall (aged 15 years and over) inactivity rates and can be largely explained by the low levels of female labour force participation due to cultural and socio-economic constraints in many countries in the regions. It is in all regions, however, and not just those where female work outside of the household is traditionally constrained, where young females make up the greater share of the total inactive youth population. The global female share of total inactive youth in 2005 was 58.2 per cent. East Asia was the only exception.

Table 4.1

Youth inactivity and inactivity rates (1995 and 2005) and female share of total inactive youth (2005)

\begin{tabular}{|c|c|c|c|c|c|c|}
\hline & \multicolumn{2}{|c|}{$\begin{array}{l}\text { Inactive youth } \\
\text { ('000s) }\end{array}$} & \multirow{2}{*}{$\begin{array}{l}\text { Female } \\
\text { share of } \\
\text { inactive } \\
\text { youth - } \\
2005(\%)\end{array}$} & \multicolumn{3}{|c|}{ Youth inactivity rate (\%) } \\
\hline & 1995 & 2005 & & 1995 & 2005 & $\begin{array}{c}\% \\
\text { change } \\
1995- \\
2005 \\
\end{array}$ \\
\hline World & $421^{\prime} 040$ & $524 ' 756$ & 58.2 & 41.1 & 45.3 & 10.1 \\
\hline Developed Economies and European Union & $58 ' 694$ & $59^{\prime} 902$ & 51.2 & 46.4 & 48.2 & 3.7 \\
\hline Central and Eastern Europe (non-EU) and CIS & $34^{\prime} 022$ & $41 ' 279$ & 55.1 & 52.8 & 58.2 & 10.2 \\
\hline East Asia & $58 ' 227$ & $74 ' 978$ & 46.2 & 24.8 & 32.7 & 31.5 \\
\hline South East Asia and the Pacific & $40 ' 845$ & $47 ' 419$ & 58.4 & 41.9 & 43.5 & 4.0 \\
\hline South Asia & $115^{\prime} 540$ & $152 ' 544$ & 65.0 & 49.4 & 52.8 & 6.8 \\
\hline Latin America and the Caribbean & $41 ' 565$ & $48 ' 319$ & 60.1 & 43.6 & 45.8 & 5.0 \\
\hline Middle East and North Africa & $37 ' 566$ & $49^{\prime} 741$ & 61.1 & 60.0 & 60.0 & 0.1 \\
\hline Sub-Saharan Africa & $34 ' 582$ & $50 ' 573$ & 61.6 & 31.8 & 34.5 & 8.3 \\
\hline
\end{tabular}

Source: Global Employment Trends (GET) Model, 2006 (see box 2 for more information).

The explanations behind the patterns in youth inactivity are likely to vary from region to region, and even from country to country, as will the implication of the trend to the interpretation of the labour market prospects of young people. The key question we are seeking to answer is: What does shrinking youth labour force participation, and hence growing youth inactivity, ${ }^{45}$ mean in terms of the well-being of the youth population? In order to answer it, we need first to look at who the inactive youths are, and second, why they are inactive.

\footnotetext{
${ }^{44}$ Resolution concerning statistics of the economically active population, employment, unemployment and underemployment, adopted by the 13th International Conference of Labour Statisticians, Geneva, October 1982; www.ilo.org/public/english/bureau/stat/download/res/ecacpop.pdf.

${ }^{45}$ Growing inactivity among youth indicates a shrinking youth labour force (active population) since the one is the inverse of the other: A person is either active or inactive; mathematically this means 100 minus the labour force participation rate equals the inactivity rate, and vice versa.
} 
Who is inactive and why?

Although we are in danger of over-generalizing when trying to identify common characteristics of a globally inactive youth population, we can at least say that there is a greater likelihood of a young person in a higher income country being inactive than one from a lower income country. ${ }^{46}$ Figure 4.1 shows the correlation between a country's income level (measured by GDP per capita at PPP in 2005) and the youth inactivity rate of the country; the trendline indicates that the two variables are positively related so that lower income levels correspond to lower levels of inactivity of the youth population while a higher income level corresponds to a higher youth inactivity rate. We can draw the tentative conclusion, therefore, that income level is one determinant of the inactivity level of youth in a country.

\section{Inactivity is not an option for youth in poor countries}

The correlation relates to the notion that in low-income economies, many young people do not have the option of staying in education due to lack of education infrastructure or high education fees (relative to the family income). In addition, opportunity costs of doing so are too high, which means that it does not always pay off to stay in school. Finally young people in poor countries are very likely to take on any job in order to maintain at least a subsistence level of support for her/himself and her/his family. Labour force participation of young people in poor households is not a matter of choice, but of necessity.

Figure 4.1

Youth inactivity rates and GDP per capita (at PPP), 2005

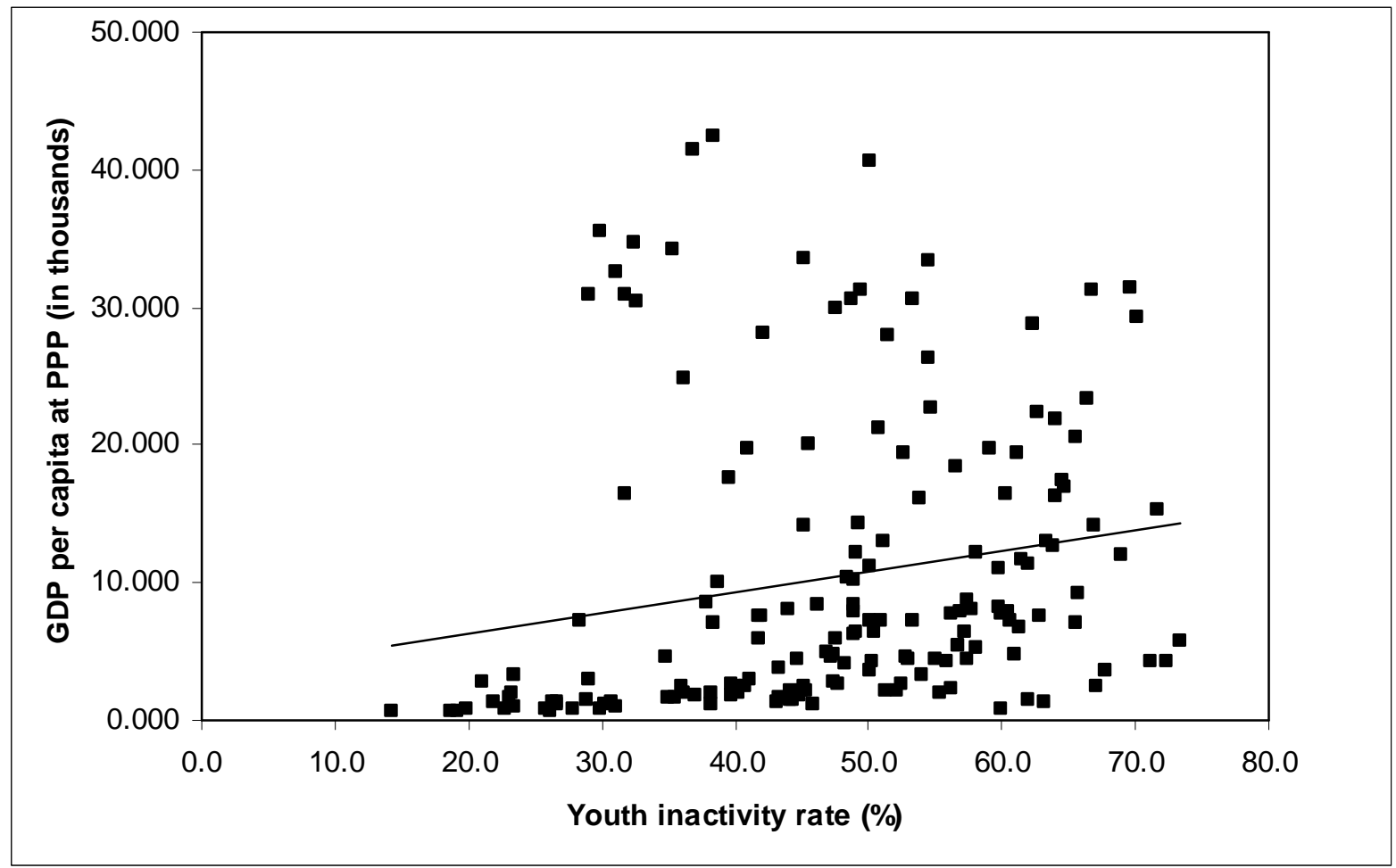

Source: ILO, 2005a, table 13 (youth inactivity rates) and International Monetary Fund, International Financial Statistics, online database (GDP per capita).

\footnotetext{
${ }^{46}$ We recognize that a country's level of overall GDP per capita says nothing about the distribution of wealth within the country and therefore mutes the evidence for an income-based explanation of youth inactivity. What would be necessary to substantiate the claim would be household level income data that could be analyzed against the current activity status of household members. Lacking such information the best we can do to provide further evidence is compare inactivity rates within poorer districts of a country with those of higher income districts. Looking at evidence from one country - Sri Lanka we can confirm that in the poorest province (Uva), where more than a third of the population lived below the national poverty line in 2002, the inactivity rate was approximately 27 per cent less than that of the wealthiest province (Western). The difference was even more striking for poor women. Women in the poorest province were 32 per cent less likely to work or seek work than women in the wealthiest province; yet they remain poor despite their efforts to earn a living. (Sources: Department of Census and Statistics, 2002a and 2002b.
} 
As for the question of why a young person would be neither working nor looking for work, and what that means to her/his welfare and future development, the answer depends on what the young person is doing as an alternative. A person could be inactive for any of the following reasons: (a) is attending school (and not working or looking for work while in school); (b) is engaged in household duties such as caring for children or other household members; (c) is retired; (d) is disabled or ill; or (e) other reasons including not knowing how/where to look for work or believing there is no work available (the "discouraged worker").

Increased participation in education is a main factor in explaining decreased economic activity among youth, especially in developed economies and Asian countries

There is not a sufficient amount of country-level data to allow us to make general statements on the distribution of inactive youth for the reasons listed above at the regional or global levels. We do know, however, that education enrolment is rising around the world; more young people are going to school and staying there for longer periods of time. Therefore, a safe assumption is that most of the increase in youth inactivity rates can be explained by an increasing number of young people staying in full-time education. This is confirmed by a review of how youth inactivity rates moved in relation to gross tertiary-level enrolment ratios ${ }^{47}$ over time in countries with available data (see figure 4.2). Although exceptions exist, there is a general trend for youth inactivity rates to increase as participation in higher level education increased (meaning the majority of country level records fall in the upper right quadrant of the chart). ${ }^{48}$

Figure 4.2

Percentage change in gross enrolment ratios at the tertiary level and the percentage change in youth inactivity rates, by region, 1990-2002

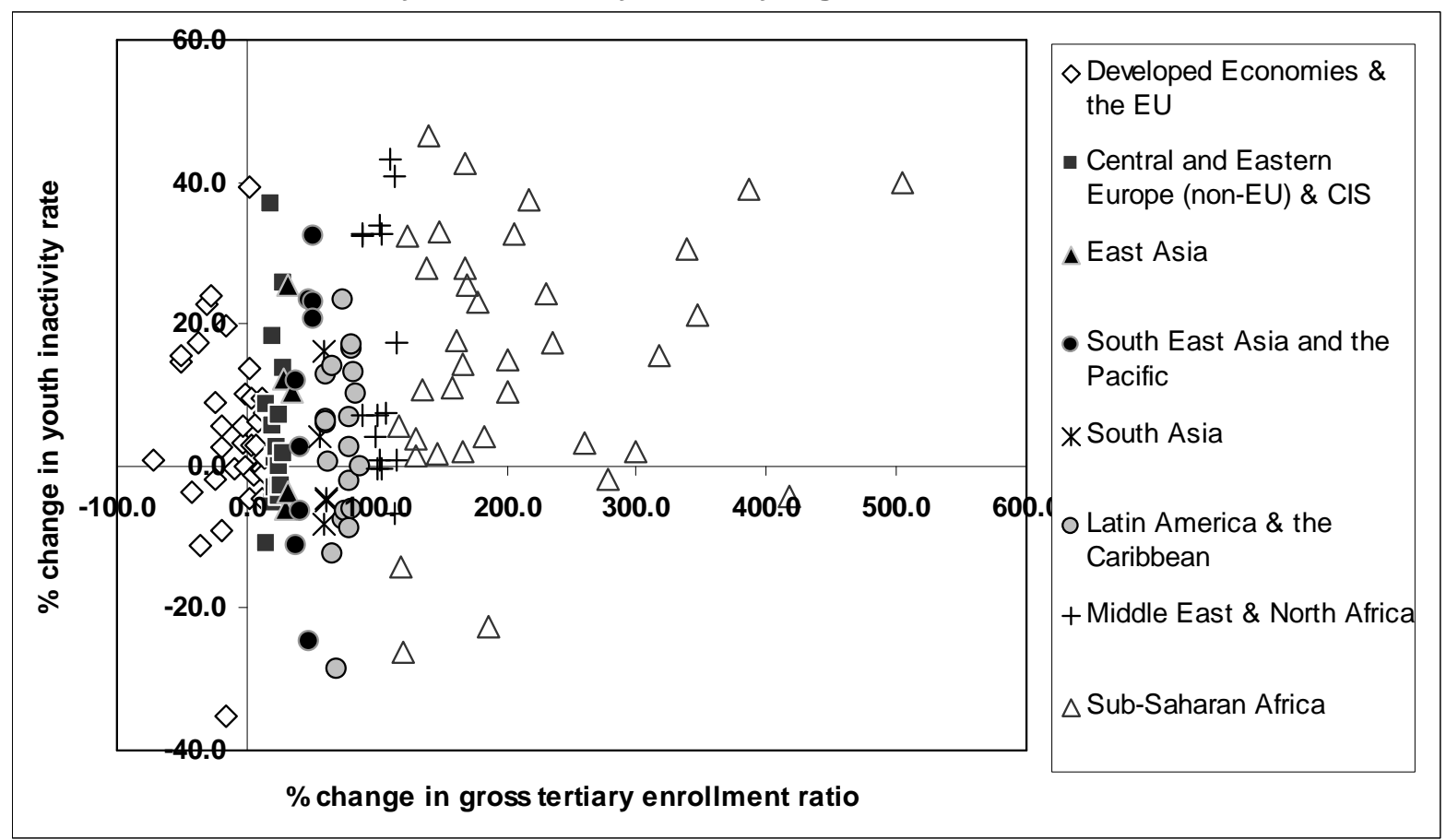

Note: earliest to latest year data are between the years of 1990 and 2002 and differ from country to country.

Source: ILO, 2005, table 13 (youth inactivity rates) and World Bank, 2005, online database, table 2.11 (gross enrolment ratios tertiary).

\footnotetext{
${ }^{47}$ Gross tertiary level enrolment ratio is defined as the ratio over time of the total persons enrolled in higher education (tertiary level), regardless of age, to the population of the age group that officially corresponds to the higher level of education in the country. The source of the information is the World Bank, 2005, table 2.11.

${ }^{48}$ There was also a positive relationship between youth inactivity rates and participation ratios at the secondary education level.
} 
The analysis of data shown in figure 4.2 also points to other interesting trends, such as:

- $\quad$ There is a strong positive correlation between the two variables - tertiary enrolment and youth inactivity rates - in the regions of the Developed Economies and the European Union, East Asia, South East Asia and the Pacific and South Asia. This can be interpreted to mean that, in these regions, the decreased economic activity of youth can be "mostly" explained by the fact that more young people are opting to stay in education rather than join the work force.

- In the regions of Central and Eastern Europe (non-EU) and CIS and Latin America and the Caribbean there is a positive, but much weaker correlation between the two variables, meaning that education alone cannot explain the decision of young people to postpone their entry to the world of work. In fact, four countries in the CIS region - Azerbaijan, the Republic of Moldova, Tajikistan and Uzbekistan, saw a decrease in the enrolment ratio of higher education while youth inactivity rates increased, making it even more clear that the reason for inactivity among youth lies elsewhere. It is in these countries that young people tend to become "discouraged" and fall outside of the labour force because they feel that no job opportunities are available (reason "e" above). Discouragement is discussed in greater detail below.

- The only region where the trend was negative - enrolment increased while youth inactivity decreased - was the Middle East and North Africa. In countries in this region, more young people are entering full time education, but the overall trend in the economic activity of young people is dominated by the almost 10 per cent increase - from 23 to 25 per cent between 1995 and 2005 - in the labour force participation of young women (and inversely, a decrease in the inactivity rate from 77 to 75 per cent). The weakness of the correlation in the region of Latin America and the Caribbean can also be explained in part by the slight increase in the labour force participation of young women there.

- The largest increases in tertiary enrolment ratios were seen in South East Asia and specifically in Cambodia and Viet Nam. There were also significant increases in higher education participation in some sub-Saharan African countries, although the enrolment ratios remain very low - generally at less than 5. The gross tertiary enrolment ratio also increased more than 300 per cent in China between 1990 and 2001 from 3 to 13.

- Declining enrolment in higher education was most common in the Central and Eastern Europe (non-EU) and CIS region and in sub-Saharan Africa. Some of the sub-Saharan African countries represented in the lower left quadrant (where negative growth was seen in both the youth inactivity rate and the enrolment ratio) - Congo, the Democratic Republic of Congo, Madagascar, Malawi, Sao Tome and Principe and Zimbabwe - underwent some form of civil unrest over the period, which likely meant that young people were more concerned with security and their livelihood of themselves and their families than furthering their education. A more likely reason for declining educational enrolment, however, was that poverty prevented more families from supporting their child's education.

\section{Discouragement as the most "damaging” reason for inactivity}

A person who is "discouraged" is one who is classified as currently inactive for a reason implying that $\mathrm{s} / \mathrm{he}$ felt that undertaking a job search would be a futile effort. Specifically, the youth might respond that s/he did not seek work because s/he has insufficient education and/or skills to get a job, that no suitable work was available locally, or that s/he did not know where to look for work. ${ }^{49} \mathrm{~A}$ discouraged youth - just like a young person who is unemployed for a long period of time - is vulnerable to facing a difficulty process of reintegrating into the labour force (see full definition of "vulnerable" below) and is in danger of feeling useless and of becoming alienated from society. For the economy, the presence of discouraged workers represents a waste of human resources and productive potential.

Few countries quantify discouragement, therefore, our knowledge on the extent of the problem is more anecdotal than factual. The Organization for Economic Co-operation and Development (OECD) publishes data for its member States, but given that the OECD represents mostly developed economies, discouragement among youth is likely to be less of a problem and likely to appear for

\footnotetext{
${ }^{49}$ For a more technical discussion of discouraged workers and the complexities of measurement, see ILO, 1990, pp. 107-08.
} 
different reasons than in the developing world. Among OECD countries, the highest share of discouraged youth in the youth population was still quite low at 5.7 per cent in Sweden in 2004 followed by Italy with 2.0 per cent. All other countries showed incidences of discouragement among youth at less than 1 per cent. ${ }^{50}$

Young people are more likely to withdraw from the labour market and not even look for work in countries of stagnant or negative growth - countries in the region of Central and Eastern Europe (non-EU) and CIS, for example. In countries such as Albania, Bosnia and Herzegovina and Serbia, which are struggling to recover from years of conflict, young people must compete with a large pool of unemployed adults for a very limited amount of job vacancies. Many give up and remain idle. Others "hide" in the education system, postponing graduation in the hope that eventually the economy will recover to a point where jobs will be available to them. In these countries, discouragement among youth is not a small phenomenon, although its exact share is difficult to measure.

\section{The share of youth who are neither in education nor employment (NEET) is a good} measure of the non-utilized labour potential of the youth population

We may not have good data on the number of discouraged youth, but we are seeing more and more data produced on the so-called NEET rate, a measure of the percentage of youth who are neither in education nor employment in the youth population. This indicator captures young people who are inactive for reasons other than participation in education (thus including the discouraged worker but also persons who are inactive for other reasons such as inactivity due to disability or due to engagement in household duties) and youth who are unemployed and is therefore a better proxy for capturing the non-utilized labour potential of the youth population. Figure 4.3 presents the available data on the youth NEET rate and confirms a high share of NEET youth in the Central and Eastern Europe region. The youth NEET rate was, on average, 33.6 per cent in the region, compared with 27.0 per cent in sub-Saharan Africa, 21.0 per cent in Central and South America and 13.4 per cent in the Developed Economies and European Union. In countries with data available by sex, there is evidence of a greater likelihood of idleness among young women than young men, with particularly large gender differences seen in Central and South America and sub-Saharan Africa (16 percentage point gaps in both regions).

It is important to keep in mind that this measure contains both unemployed non-student youth and youth who are inactive for reasons other than educational enrolment, including discouragement (i.e. inactive non-students). Ideally, one would be able to isolate each subset from the number of youth classified as NEET to see which constitutes the bulk of the non-utilized labour potential measure. Unfortunately, the detailed information from which to disaggregate the NEET total is available only for the OECD group of countries to date. For the OECD region, however, we are able to conclude that the majority of youth who were neither in education nor employment were inactive non-students (57 per cent, on average) while the remainder were unemployed non-students (43 per cent). The larger NEET shares for young women than young men in the regions of Central and South America and subSaharan Africa can probably be explained by the fact that, due to cultural and economic constraints, young women in the regions oftentimes fall outside of the labour force because they are required to tend to household duties. This would result in a larger number of inactive non-students for young females than young males. Also, enrolment rates are likely to be lower for young females than young males meaning that more young males would be in education and thus not counted as NEET.

\footnotetext{
${ }^{50}$ Data on discouraged workers are from the OECD Statistics online database available at http://stats.oecd.org/WBOS/default.aspx; data extracted 2006/07/14.
} 
Figure 4.3

Share of youth neither in employment nor education (NEET) in total youth population, regional averages ${ }^{51}$

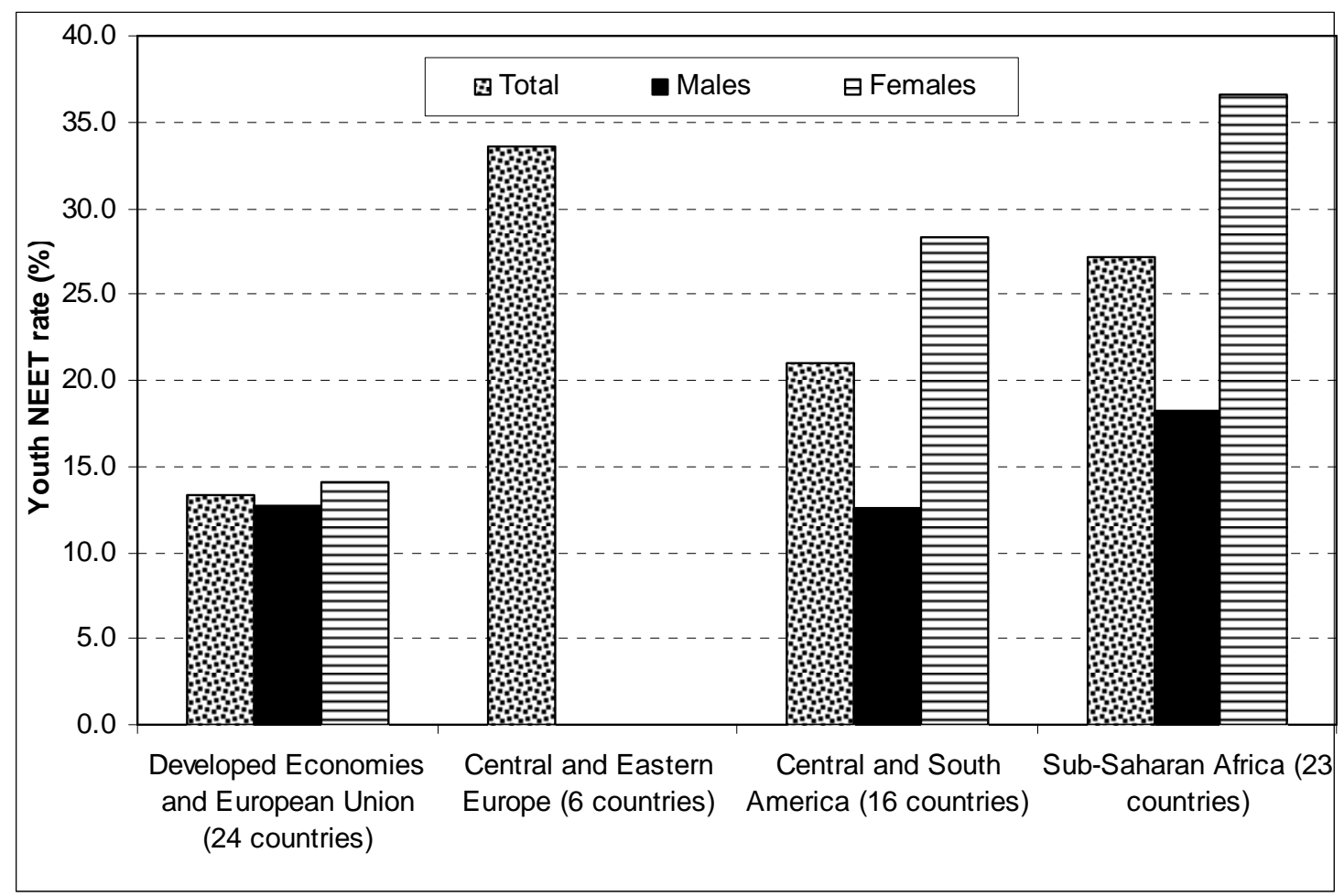

Sources: Developed Economies and European Union: Authors' calculation based on data from OECD Statistics online database available at http://stats.oecd.org/WBOS/default.aspx; Central and Eastern Europe (non-EU) and CIS: data from Kolev and Saget, 2005, except for Turkey, which is authors' calculation based on data from OECD Statistics; Central and South America: data from Diez de Medina, 2001, except for Mexico, which is authors' calculation based on data from OECD Statistics, and Peru which comes from Chacaltana, 2006; sub-Saharan Africa: data from Guarcello, 2005 and UN-Habitat, Global Urban Observatory, June 2004.

\subsection{Explaining labour market vulnerability among youth}

Who are the most vulnerable youth?

For the purpose of this report, the ILO defines a vulnerable youth as one whom, due to socioeconomic (and sometimes political) circumstances, is vulnerable to facing difficulties in the process of labour market integration or, if working, is vulnerable to working under inadequate conditions. As a result of labour-related vulnerabilities, young men and women are weaker not only as workers, but also as citizens and agents of change; they cannot exercise their rights as citizens because they have limited or no rights as workers; they cannot provide a better future to their children and dependants because they do not earn enough to lift themselves and their families out of poverty; they cannot hope for income security as they age since they do not have access to social protection. Labour market vulnerability among youth may lead to their loss of self-esteem, to social exclusion, to impoverishment, to idleness and potential attraction to illicit activities, and finally to feelings of frustration with their situation and to directing their frustration on the society that created it. The

\footnotetext{
${ }^{51}$ Average of 24 countries in the Developed Economies and European Union region (Australia, Austria, Belgium, Canada, Czech Republic, Finland, France, Germany, Greece, Hungary, Iceland, Ireland, Italy, the Netherlands, New Zealand, Norway, Poland, Portugal, Slovakia, Spain, Sweden, Switzerland, United Kingdom and the United States) in the latest year of data availability (2003, except for Germany, Italy, the Netherlands and the United States, 2002, and New Zealand, 2001). Central and Eastern Europe is an average of six countries (Albania, Bosnia and Herzegovina, Bulgaria, Romania, Serbia and Turkey) in c. 2001, except for Turkey, 2003. Central and South America is average of 16 countries (Argentina, Bolivia, Brazil, Chile, Colombia, Costa Rica, Ecuador, El Salvador, Honduras, Mexico, Nicaragua, Panama, Paraguay, Peru, Uruguay and Venezuela) in years 1997 or 1998, except for Peru, 2002 and Mexico, 2003. Sub-Saharan Africa is average of 23 countries (Benin, Burkina Faso, Burundi, Cameroon, Central African Republic, Chad, Côte d'Ivoire, Ethiopia, Gambia, Ghana, Guinea Bissau, Kenya, Madagascar, Malawi, Mali, Mozambique, Nigeria, Sao Tome and Principe, Togo, United Republic of Tanzania, Uganda, Zambia and Zimbabwe) in an undefined year.
} 
danger is that with a buildup of grievances, vulnerable youth lose faith in the system of governance that they feel has failed to live up to their expectations.

How does one identify the most vulnerable youth, especially given that the definition given spans across multiple activity statuses? For identifying the youth most vulnerable to being unable to fully integrate into the labour market without assistance, the indicator of youth who are neither in education nor employment is a good place to start. These are the young people who, due to a lack of economic demand, are suffering most from a deficit of decent work opportunities. As a result, they either look for work or simply bide their time hoping that conditions will eventually improve. As much as one-third of the youth population in struggling post-conflict economies such as Bosnia and Herzegovina and Serbia is in danger of being lost in a system where they are unable to contribute to their own well-being, let alone to the well-being of their families or society as a whole. Likewise, in Africa there are millions of alienated young people, particularly in desperately poor urban areas, whose lives are defined simply as "enduring". 52

It is important to broaden the vulnerability spectrum to include also young people who are working because, as stated in section 2.2, the welfare of young people depends on more than simply having work. It is the quality of work that matters. A young person who is in an inadequate employment situation - whether defined in terms of wage, hours, job security or social protection - is also susceptible to poverty, to dissatisfaction, to alienation, etc. With regards to figure 1, we discuss the concepts of "underemployment" versus "full employment". Youth who work under unsatisfactory conditions, as determined by any number of qualititative characteristics (hours, inadequate remuneration, poor use of ones skills, lack of security, lack of benefits, to name a few) fall under the very broad categorization of "underemployed youth" ${ }^{, 3}$ and, therefore, constitute a portion of the young people who fall within the decent work opportunity deficit. Additional information, disaggregated by age, at the country level is needed before the conditions of work aspects of vulnerability could be estimated at the global or regional level. The only quantifiable approximation we have to date is that of the working poor youth - 125 million youth at the US\$1 a day level in 2005, or 22.7 per cent of employed youth - who due to inadequate remunerative returns to their labour would easily qualify as youth who lack decent work opportunities.

Figure 4.4 attempts to place the risk of labour market vulnerability among young people in a spectrum based on the current activity of the youth and the potential for future labour market integration. Chances of future integration into the labour market (without intervention) increases from left to right so that a young person whose main reason for inactivity was because s/he was attending school or training full time is more likely to enter the labour market in the future than a young person who is no longer seeking work because s/he felt "discouraged". The former person's labour market vulnerability, therefore, could be rated as "low". Likewise, (re)integration into the labour market becomes more difficult as the period of unemployment lengthens due to the jobseeker's eventual loss of skills, employers' biases and the increasing likelihood of the young person becoming "discouraged". Therefore, the longer the spell of unemployment, the more vulnerable the youth.

Inactivity is not only a waste of potential but also a risk to societies. It should be top priority for countries to concentrate not only on the unemployed youth but also on the involuntarily inactive especially the discouraged - youth. In the poorest countries, it must be an important role of national policies and programmes, backed by international aid, to reach the most vulnerable youth and to bring them back into the fold of a civil society that can benefit from their participation. To explain inactivity even further it is necessary to get more detailed information on its causes because it is only based on an analysis of relevant data that effective programmes and policies can be designed.

\footnotetext{
${ }^{52}$ Sommers, 2003, p. 36 .

${ }^{53}$ It is worth repeating that time-related underemployment - underemployment measured as a deficiency of working hours remains the only formulation of underemployment that has been agreed on and properly defined within the international community of labour statisticians. See the Resolution concerning the measurement of underemployment and inadequate employment situations, adopted by the 16th International Conference of Labour Statisticians, Geneva, 1998; website: www.ilo.org/public/english/bureau/stat/download/res/underemp.pdf.
} 
Figure 4.4

Determining vulnerability among young people

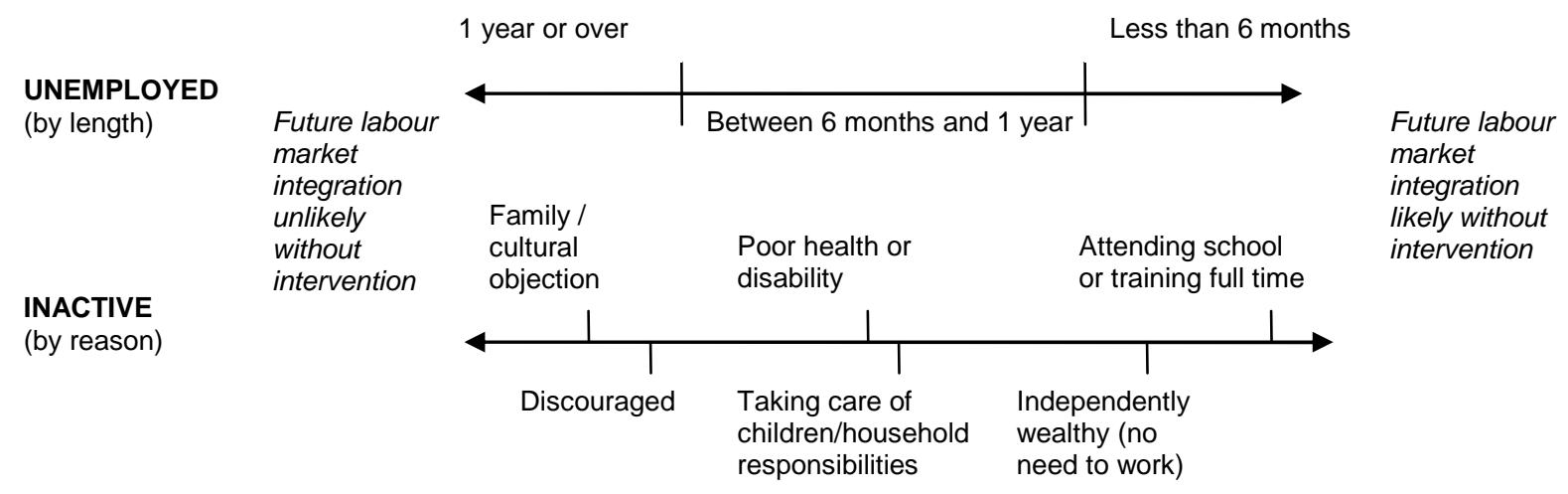

\section{High}

VULNERABILITY

EMPLOYED

(by qualitative

characteristics)

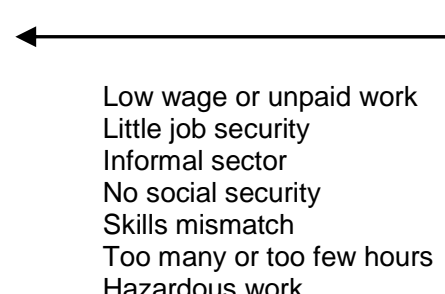

"Decent" wage

Job security

Formal sector

Satisfactory hours

Safe work

Too many or too few hours Social security 


\section{The school-to-work transition}

\subsection{What does "transition" mean?}

The inevitable transition from youth to adulthood encompasses many "firsts" for individuals first job experience and first wage, first departure from education and from the family household, first vote, first struggle for self-dependence, etc. Of course there are many different variations within the life phase from youth to adulthood; some young people may never join the labour force or some may never work for a wage; some will never set up an individual household, but will remain instead within a larger family compound; some may have started working at a very early age (child labourers); others might already have children to look after. In the report on "Working out of poverty", the ILO DirectorGeneral emphasized that "identifying the key stages of life when people are vulnerable to falling into poverty is the starting point for understanding the dynamics of life and work of poor communities". ${ }^{4}$ The transition from youth to adulthood is one of these "key stages" that can determine a person's chance of escaping poverty, and as such, warrants special attention. But of course there is no one path to adulthood and the task of prescribing paths, with all the milestones, from region to region or country to country is a risky business given the variety of culturally-driven beliefs of what adulthood means and the vastly different economic constraints and institutional barriers that might block the youth's path in getting there.

It is beyond the scope of this report to touch on all the possible influences in the life course of young men and women into adulthood. Instead, we focus on the transition from school to work, which we would argue is probably the most significant for determining the economic (and social) well-being of the individual and, if taken collectively, for influencing the level of development of the country.

\subsection{The ILO concept of the school-to-work transition: measuring the transition to "decent work"}

Two things are of interest from the ILO's point of view: first, how do we quantify and explain the number of young people who are "starting right", meaning they are moving from school into "decent" employment that makes the most of their productive potential without significant difficulty and, conversely, those who face a "difficult" transition? Second, are there lessons to be learned in characterizing factors that influence the length and the difficulty of the transition? The ILO school-towork transition survey (SWTS) was developed as a tool to quantify, according to a systematic schema, the relative ease or difficulty of labour market entry of young people as they exit school. By starting from the premise that a person has not "transited" until they are settled in a job that meets a very basic criteria of "decency", namely a permanency that can provide the worker with a sense of security (e.g. a permanent contract), or a job that the worker feels personally satisfied with, the ILO is introducing a new quality element to the standard definition of school-to-work transition. ${ }^{55}$

The analytical framework associated with the SWTS allows us to first assess the characteristics of youth who are still in school, employed or self-employed, unemployed or outside of the labour force for reasons other than full-time studying. Then we use survey results to estimate: 1) the number of young people who have completed their transition into "decent work"; 2) those who are still in transition - that is, either unemployed or employed in a job that is temporary or unsatisfactory; and 3) the number of young people who have not yet transited either because they remain in school or are outside of the labour market with no plans to work in the future. For the youth who have completed their transition, we can analyze the relative ease or difficulty of their transition (easy, middling or difficult) based on their experience before entering their current job: for example, was it a direct transition or did they undergo numerous spells of unemployment and temporary employment; if the latter, how many and how long?

\footnotetext{
${ }_{55}^{54}$ ILO, 2003, p. 22.

${ }^{55}$ There is a wealth of literature on the nature of the school-to-work transition, but the transition period is generally defined in simple terms as the time period after which a person finishes school and begins his/her first post-graduation job. An excellent example is the recent work from Guarcello, et al, 2005.
} 
The presentation and dissemination of the information should feed directly into policy making relating to youth employment and development at the national level. At the regional level, the surveys should provide examples and stimuli for other countries to engage in similar approaches to exploring the variables that explain the outcome of youth employment and using results as input in the policymaking process.

\subsection{Some preliminary results}

With survey results ${ }^{56}$ now available from Azerbaijan, China, Egypt, the Islamic Republic of Iran (henceforth, "Iran"), Jordan, the United Nations Administered Province of Kosovo (henceforth, "Kosovo"), Nepal and the Syrian Arab Republic (henceforth, "Syria"), we have a good basis for already highlighting some key findings and identifying common themes. (See table 5.1 for information relating to the survey size, coverage and reference period for the SWTS in each country.) The rest of this section serves as an example of the type of analysis that can be made based on the survey results. ${ }^{58}$ However, due to the vast differences among the countries surveyed in terms of geographic size, level of development, etc., we do not attempt here to draw any conclusions based on a comparative analysis of survey results.

Table 5.1

Sampling size, reference period and survey coverage

\begin{tabular}{|l|c|l|l|}
\hline & $\begin{array}{c}\text { Sample size } \\
\text { (young people } \\
\text { aged 15-29 } \\
\text { years }\end{array}$ & \multicolumn{1}{|c|}{ Reference period } & Geographic coverage \\
\hline Azerbaijan & 3,008 & August 2005 & national \\
\hline China & 6,676 & January to March 2005 & 4 urban areas - Dalian, Changsha, Liuzhou and Tianjin \\
\hline Egypt & 5,423 & September to October 2005 & national \\
\hline Iran & 3,245 & September to October 2005 & 3 provinces - East Azarbayejan, Lorestan and Tehran \\
\hline Jordan & 1,739 & June to July 2004 & 3 regions - Amman, Irbid and Karak \\
\hline Kosovo & 1,352 & September to October 2004 & $\begin{array}{l}5 \text { (of 7) regions - Pristina, Mitrovica, Gijlan, Gjakova, } \\
\text { Prizren }\end{array}$ \\
\hline Nepal & 2,400 & September to October 2005 & $\begin{array}{l}5 \text { districts - Banke, Bhaktapur, Kathmandu, Lalitpur } \\
\text { and Morang }\end{array}$ \\
\hline Syria & 2,000 & November 2005 & 4 provinces - Aleppo, Damascus, Hamah and Tartus \\
\hline
\end{tabular}

* The surveys in Jordan and Kosovo covered the youth population aged 15-24 years.

\section{Economic activity status of young men and women}

In China, youth move quickly into employment, but in the other countries, youth are more likely to stay in school (see figure 5.1).

China differs from the other countries surveyed in the high share of employed youth in the surveyed population (71.1 per cent). Among other countries, the largest share of young males surveyed were employed in Egypt (44.3 per cent) and Syria (46.6 per cent), while the largest share of young males still in school and therefore not yet started their transition was in Nepal (52.7 per cent).

Young women are mainly inactive (and not in education).

Inactivity was the most likely outcome of young women in Azerbaijan (36.8 per cent), Egypt (60.4 per cent), Nepal (43.0 per cent) and Syria (57.5 per cent), reflecting the large number of young women who stay at home rather than attend education or work. This is either the result of economic recession that makes the opportunity cost of leaving the housework, childcare, etc. to seek work in a

\footnotetext{
${ }^{56}$ Final reports for all of the country surveys mentioned above will be made available by the end of 2006. See website www.ilo.org/youth for more information. A more detailed "synthesis" of survey results will also be prepared and expected for publication in early 2007.

${ }^{57}$ A previous generation of ILO school-to-work transition surveys, prior to the current refinement of the questionnaire and the analytical framework, were run in conjunction with the ILO Gender Promotion Programme in previous years. Final Reports are available at the following links: www.ilo.org/public/english/employment/gems/download/wp14.pdf (Indonesia), www.ilo.org/public/english/employment/gems/action/vietnam.htm (Viet Nam), and www.ilo.org/public/english/employment/strat/download/esp19.pdf (Sri Lanka).

${ }^{58}$ More in-depth analyses will be available in the forthcoming reports.
} 
very tight job market too high (Azerbaijan and Nepal) and/or because the economic participation of women is not a widely accepted part of the culture (Egypt and Syria).

In Kosovo the largest share of youth surveyed was unemployed; in Syria, unemployed was the principal activity status of young men.

In Kosovo, the share of youth who were unemployed is troubling for both sexes (38.3 percent, young men; 29.4 percent, young women), while in Syria it was only young men who showed a disturbing likelihood of being unemployed (20.4 per cent).

Figure 5.1

Distribution of youth by current activity status, by sex

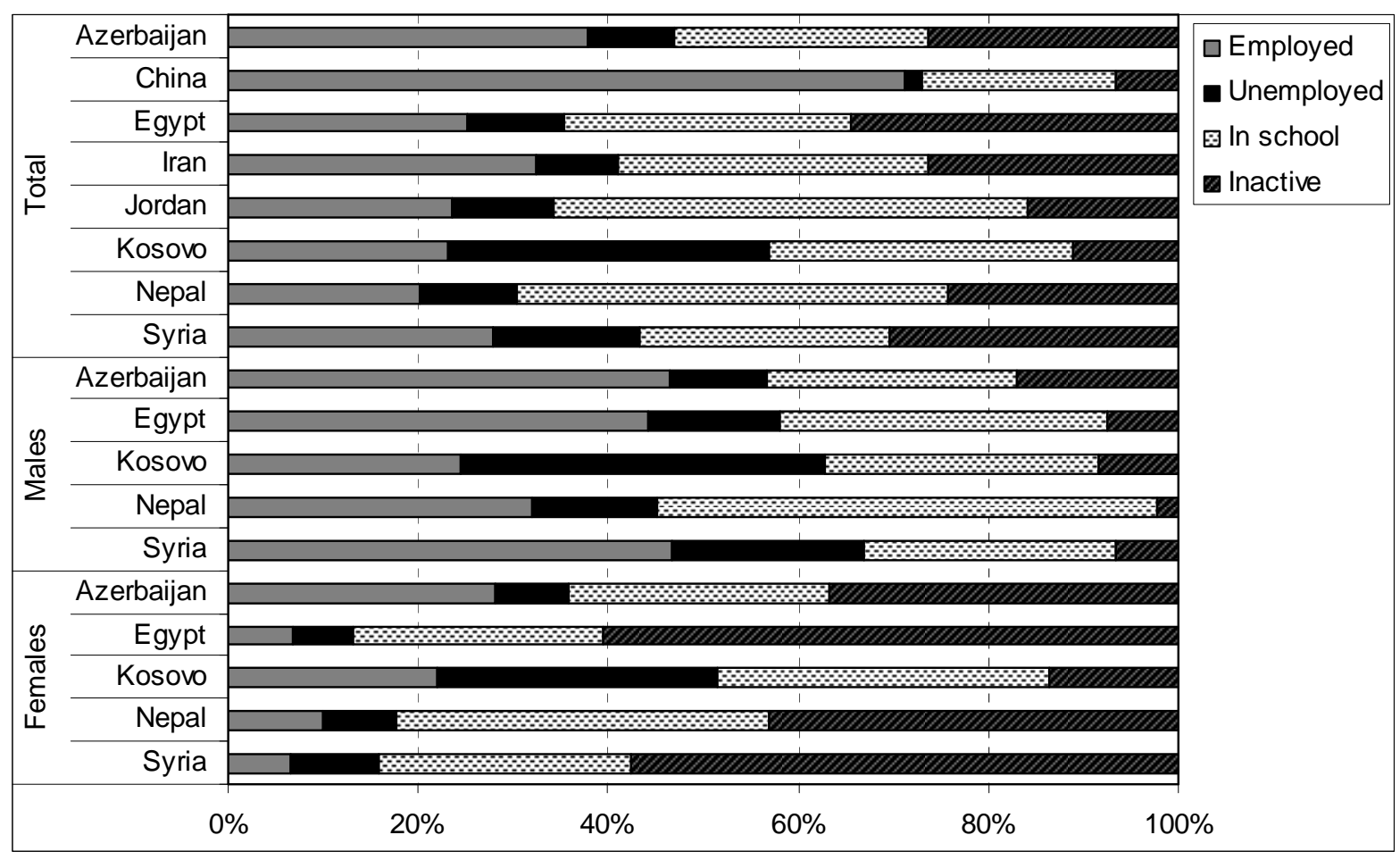

Sources of data in this table and those that follow are the ILO school-to-work transition surveys: draft reports and raw data. Final survey reports will be available soon. Some methodological information on each country survey is included in table 5.1 .

\section{Judging the quality of the transition}

Many youth work without the protection of employment contracts in China (38.0 per cent), Egypt (69.1 per cent) and Kosovo (19.2 per cent) (see table 5.2).

A young person working without a contract runs the risk of easily losing the job or being exploited, both of which should be avoided when aiming for a "decent" transition.

Table 5.2

Distribution of employed youth by type of employment contract

\begin{tabular}{|l|c|c|c|c|}
\hline & $\begin{array}{c}\text { No contract } \\
(\%)\end{array}$ & $\begin{array}{c}\text { Temporary } \\
\text { contract of less } \\
\text { than 1 year (\%) }\end{array}$ & $\begin{array}{c}\text { Fixed term } \\
\text { contract of 1-3 } \\
\text { years (\%) }\end{array}$ & $\begin{array}{c}\text { Unlimited } \\
\text { contract (no } \\
\text { term limit) (\%) }\end{array}$ \\
\hline China & 38.0 & 20.0 & 36.0 & 4.0 \\
\hline Egypt & 69.1 & 3.4 & 7.6 & 19.9 \\
\hline Kosovo & 19.2 & 9.3 & 31.4 & 37.0 \\
\hline
\end{tabular}

School-to-work transitions are lengthy and multi-stepped processes and few youths have "finished" by the age of $29^{59}$ (see figure 5.2).

There are various ways of interpreting the results shown in the following figure. First, taken together with the results of the distribution of the population by current status, it is interesting to note

\footnotetext{
${ }^{59}$ The school-to-work transition surveys cover the age group 15 to 29 years, with the exceptions of Jordan and Kosovo, which used the standard age group 15 to 24 years.
} 
that although 71 per cent of the young Chinese surveyed were working, only 17 per cent of the sample could be said to be in a "decent" job that they were completely satisfied with and would not wish to change in the future (i.e. had finished their transition). Second, comparing the shares by transition stage within countries, we find that, with the exception of Iranian males, in general less than one-fifth of youth in all surveyed countries had finished the transition. The rest had either not yet started their transition because they were still studying, were inactive with no future prospect of seeking work, were in less than satisfactory situations such as temporary work or in work that did not suit them, or were still looking for work.

Figure 5.2

Distribution of youth by stage of transition

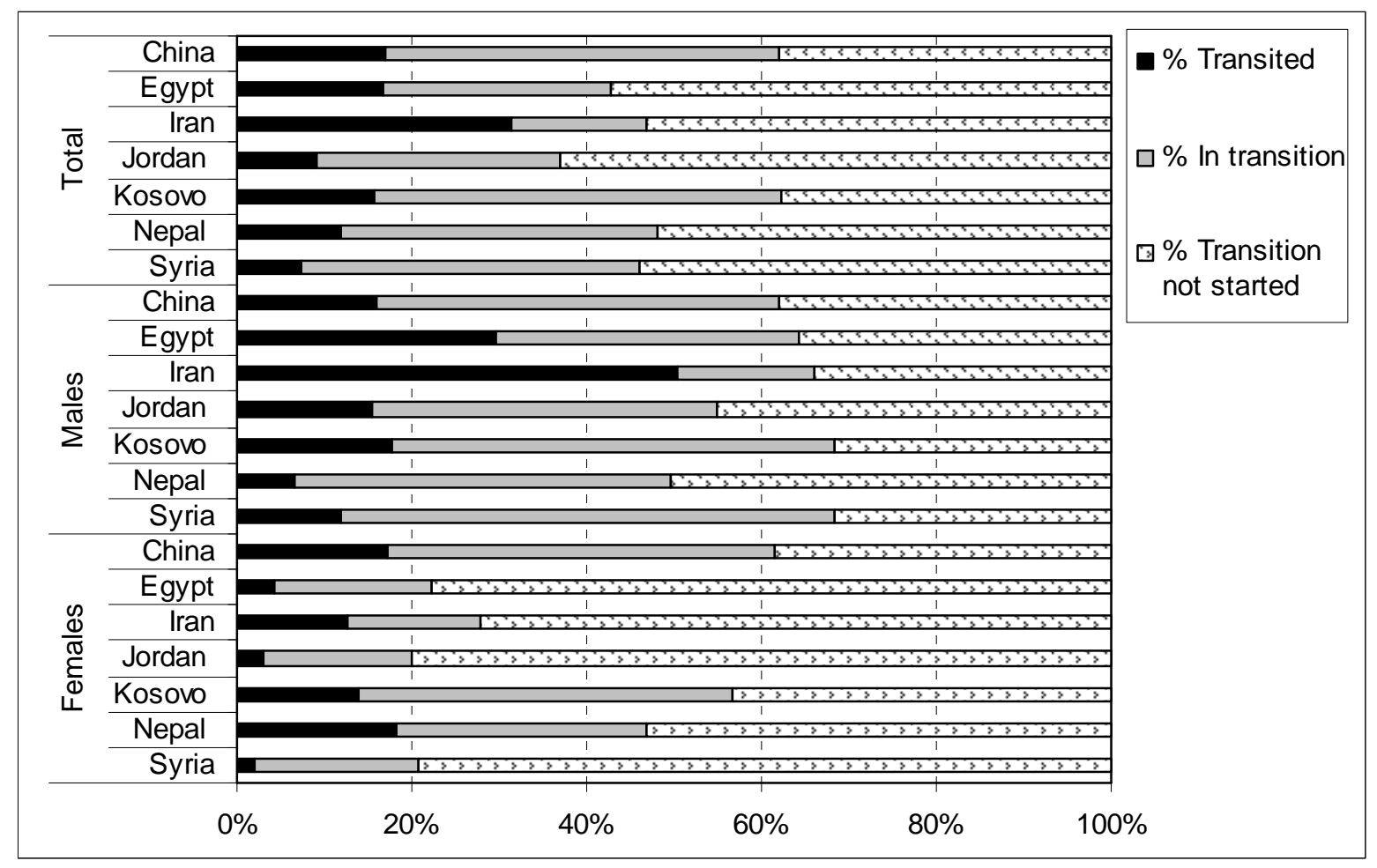

Note: Youth who have "transited" include those who are working either in a job with a permanent contract or in a job that they are satisfied with and do not wish to change. Youth "in transition" include young people who are either unemployed or employed in a job that is temporary or unsatisfactory. "Transition not started" includes young people who have not yet started the transition into the labour market either because they remain in school or are outside of the labour market with no plans to work in the future.

Youth in transition by in-transition activity status differ across countries.

Most of the youth in transition were in temporary or non-career jobs ${ }^{60}$ in China, Jordan and Syria, while in Egypt and Iran the in-transition youth were more likely to be unemployed. Only in Nepal was the largest share (49.4 per cent) of youth inactive but with plans to take up future work (most likely biding their times until economic conditions improve) (see table 5.3).

Table 5.3

Distribution of youth in transition, by current activity status

\begin{tabular}{|l|c|c|c|}
\hline & $\begin{array}{c}\text { Employed in } \\
\text { temporary or non- } \\
\text { career job (\%) }\end{array}$ & $\begin{array}{c}\text { Unemployed } \\
(\%)\end{array}$ & $\begin{array}{c}\text { Inactive with intent to } \\
\text { take up future work } \\
(\%)\end{array}$ \\
\hline China & 64.0 & 28.0 & 8.0 \\
\hline Egypt & 32.4 & 38.7 & 29.0 \\
\hline Iran & 6.9 & 55.3 & 37.8 \\
\hline Jordan & 46.4 & 35.3 & 18.3 \\
\hline Nepal & 22.5 & 28.2 & 49.4 \\
\hline Syria & 53.0 & 39.5 & 7.4 \\
\hline
\end{tabular}

\footnotetext{
${ }^{60} \mathrm{~A}$ "non-career job" is defined as one that the young worker (a) defines as unsatisfactory regardless of the reason and (b) expresses a desire to change.
} 
Bad health and disability play a major role for inactivity in Kosovo.

Reasons for inactivity (beyond education) show a surprising share of young men and women in Kosovo who were inactive due to bad health or disability. Household responsibilities remain the main barrier to young female labour force participation, but discouragement also rates high as a reason for both young men and women (see table 5.4).

Table 5.4

Distribution of youth outside of the labour force by reason for inactivity, by sex

\begin{tabular}{|l|c|c|c|c|c|c|c|c|c|c|}
\hline & \multicolumn{2}{|c|}{$\begin{array}{c}\text { Bad } \\
\text { health/disability (\%) }\end{array}$} & $\begin{array}{c}\text { Housework and/or } \\
\text { childcare } \\
\text { responsibilities (\%) }\end{array}$ & $\begin{array}{c}\text { Family does not } \\
\text { give permission } \\
\text { to work (\%) }\end{array}$ & \multicolumn{3}{|c|}{ Discouraged (\%) } & \multicolumn{2}{|c|}{ Other (\%) } \\
\hline & Males & Females & Males & Females & Males & Females & Males & Females & Males & Females \\
\hline China & 39.0 & 21.0 & 6.0 & 50.0 & 0.0 & 0.0 & 33.0 & 19.0 & 22.0 & 10.0 \\
\hline Kosovo & 66.1 & 32.3 & 0.0 & 27.3 & 0.0 & 2.6 & 22.2 & 21.3 & 11.7 & 16.5 \\
\hline Syria & 28.8 & 2.9 & 19.3 & 43.7 & 13.5 & 33.3 & 19.2 & 10.1 & 19.2 & 10.0 \\
\hline
\end{tabular}

Large shares of youth identified the lack of available job vacancies as their main obstacle to finding work (see table 5.5).

It is interesting to view what in-transit youth identified as their main obstacle to finding work or finding their preferred work since the responses reflect the mindset of the young person at the time. In Egypt, Jordan and Kosovo, a clear majority (70.2, 65.4 and 54.5 per cent, respectively) saw an insufficient number of job vacancies as their main obstacle. Youth who blame such an "external" cause (meaning outside of their control) are more likely to feel angry about their situation and might act on their anger.

Table 5.5

Main obstacles to finding decent work identified by in-transit youth

\begin{tabular}{|l|c|c|c|c|}
\hline & $\begin{array}{c}\text { Not enough jobs } \\
\text { available (\%) }\end{array}$ & $\begin{array}{c}\text { Insufficient level of } \\
\text { education (\%) }\end{array}$ & $\begin{array}{c}\text { Lack of experience } \\
\text { (\%) }\end{array}$ & Other (\%) \\
\hline Egypt & 70.2 & 15.8 & 2.6 & 11.4 \\
\hline Iran & 35.8 & 14.0 & 20.3 & 29.9 \\
\hline Jordan & 65.4 & 2.7 & 11.7 & 20.2 \\
\hline Kosovo & 54.5 & 22.8 & 12.4 & 10.3 \\
\hline Nepal & 8.7 & 52.2 & 8.0 & 31.1 \\
\hline Syria & 16.2 & 42.9 & 15.7 & 25.2 \\
\hline
\end{tabular}

A higher education level does not guarantee an easier transition.

Looking at the distribution of transition stage by education level, in Egypt and Nepal it is the youth with low levels of education (no education through secondary level) who are more likely to have completed their school-to-work transition than to remain in transition. (See figure 5.3.) At the higher education level, only 16 per cent of tertiary degree holders had transited compared to 26 per cent who were still in transition in Egypt. A look at the distribution of education levels of youth who have completed their transition reveals similar results: a youth who had completed the school-to-work transition was more likely to have only secondary level education in Iran and Nepal and only primary level education in Syria (see table 5.6). The results are likely to reflect higher demand in these countries for manual/production labour requiring less education compared to higher-skilled, professional work, typically in services. In many developing countries, the demand for highly educated labour is not keeping pace with the supply. 
Figure 5.3

Distribution of educational level of respondents by stage of transition, Egypt and Nepal

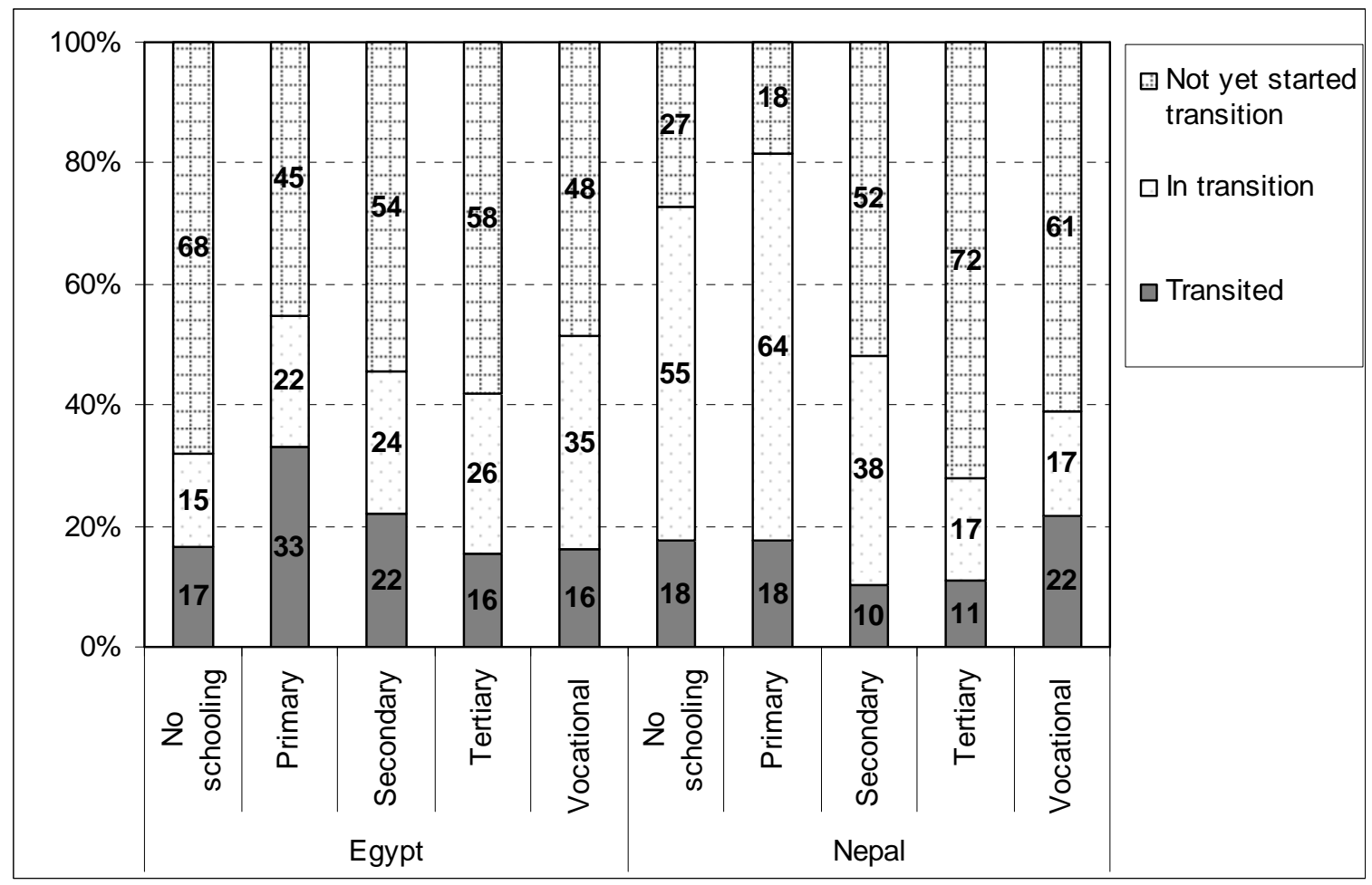

Table 5.6

Transited youth by education level

\begin{tabular}{|l|c|c|c|c|c|}
\hline & $\begin{array}{c}\text { No schooling } \\
(\%)\end{array}$ & $\begin{array}{c}\text { Primary } \\
(\%)\end{array}$ & $\begin{array}{c}\text { Secondary } \\
(\%)\end{array}$ & $\begin{array}{c}\text { Tertiary } \\
(\%)\end{array}$ & $\begin{array}{c}\text { Vocational } \\
(\%)\end{array}$ \\
\hline China & 0.0 & 2.0 & 16.0 & 53.0 & 29.0 \\
\hline Iran & 0.0 & 37.8 & 46.4 & 15.0 & n.a. \\
\hline Nepal & 14.0 & 12.6 & 55.2 & 16.4 & 1.7 \\
\hline Syria & 9.5 & 41.3 & 37.2 & 11.9 & n.a. \\
\hline \multicolumn{7}{|c|}{ n.a. $=$ Not available }
\end{tabular}

\section{Is there a mismatch between supply and demand?}

For skilled professional jobs, educational levels play a role for employers, but work experience is more important.

Employers ranked the education level of the young job applicant for skilled professional positions as the most important factor influencing their hiring decisions in only two of the five countries with data (Jordan and Nepal). Employers in China and Kosovo rated work experience as the most important, while in Syria, employment decisions continue to be very much biased by the sex of the applicant (see table 5.7). In the countries studied there is likely to be more supply than demand for youth with higher education degrees, which leads to a situation in which employers push up the educational requirements of even basic skill positions. The result is high levels of skills-based underemployment (where employees are over-qualified for the work they do). Educational qualifications are much more important in applicants for professional posts; 76 per cent of employers in Egypt and 73 per cent of employers in Nepal expected applicants to have a university education or higher (see table 5.8).

Work experience is most important for manual/production workers.

For manual/production posts, the most important factor influencing the hiring decisions of employers was the work experience of the applicant, followed by their previous training (see table 5.7). The education level sought by employers of young manual/production workers is rarely more than completion of the secondary level, when any preferences exist (see table 5.8). 
Table 5.7

Most important factors influencing employers' decisions when hiring young men and women, by type of post (professional/administrative or manual/production)

\begin{tabular}{|c|c|c|c|c|c|c|c|c|c|c|}
\hline \multirow[b]{2}{*}{ Quality } & \multicolumn{2}{|c|}{ China } & \multicolumn{2}{|c|}{ Jordan } & \multicolumn{2}{|c|}{ Kosovo } & \multicolumn{2}{|c|}{ Nepal } & \multicolumn{2}{|c|}{ Syria } \\
\hline & $\begin{array}{l}\text { Profes- } \\
\text { sional }\end{array}$ & Manual & $\begin{array}{l}\text { Profes- } \\
\text { sional }\end{array}$ & Manual & $\begin{array}{l}\text { Profes- } \\
\text { sional }\end{array}$ & Manual & $\begin{array}{l}\text { Profes- } \\
\text { sional }\end{array}$ & Manual & $\begin{array}{l}\text { Profes- } \\
\text { sional }\end{array}$ & Manual \\
\hline Sex & 0.0 & 0.0 & 15.4 & 4.3 & 4.0 & 5.2 & 0.0 & 2.5 & 32.9 & 13.9 \\
\hline Education & 41.2 & 1.5 & 30.3 & 4.6 & 30.8 & 6.0 & 45.8 & 4.2 & 25.9 & 9.5 \\
\hline Marital status & 0.5 & 4.9 & 1.7 & 1.1 & 2.0 & 4.0 & 0.0 & 0.0 & 0.7 & 1.3 \\
\hline Previous training & 4.3 & 27.8 & 8.3 & 15.8 & 20.4 & 9.2 & 4.2 & 4.2 & 10.5 & 17.7 \\
\hline Other & 10.9 & 18.9 & 14.4 & 21.5 & 0.0 & 0.0 & 1.7 & 5.9 & 3.5 & 1.9 \\
\hline
\end{tabular}

Table 5.8

Employers' preferences of education level when hiring young men and women, by type of post (professional/administrative or manual/production)

\begin{tabular}{|c|c|c|c|c|c|c|c|c|}
\hline \multirow[b]{2}{*}{ Education level } & \multicolumn{2}{|c|}{ Egypt } & \multicolumn{2}{|c|}{ Kosovo } & \multicolumn{2}{|c|}{ Nepal } & \multicolumn{2}{|c|}{ Syria } \\
\hline & $\begin{array}{c}\text { Profes- } \\
\text { sional }\end{array}$ & Manual & $\begin{array}{l}\text { Profes- } \\
\text { sional }\end{array}$ & Manual & $\begin{array}{l}\text { Profes- } \\
\text { sional }\end{array}$ & Manual & $\begin{array}{l}\text { Profes- } \\
\text { sional }\end{array}$ & Manual \\
\hline Primary education & 0.5 & 7.6 & 0.4 & 8.8 & 0.0 & 4.2 & 31.3 & 61.2 \\
\hline Technical/vocational training & 2.9 & 22.6 & 45.4 & 69.7 & 10 & 2.5 & n.a & n.a \\
\hline Secondary & 13.2 & 20.3 & 20.7 & 20.3 & 17.5 & 28.3 & 28.4 & 19.7 \\
\hline University education or higher & 76.1 & 3.3 & 33.5 & 1.2 & 72.5 & 5.8 & 39.5 & 9.2 \\
\hline No education preference & 7.3 & 46.2 & 0.0 & 0.0 & 0.0 & 59.2 & 0.7 & 9.9 \\
\hline
\end{tabular}

Survey results do not support the claim that the reason employers do not hire young people is because they lack the basic skills required.

The general assessment by employers of the skill levels of young job applicants and young workers revealed an overall satisfaction with the level of skills shown by young men and women (see figure 5.4).

Figure 5.4

Employers' general skills assessment of young job applicants and young workers, by type of skill and overall general preparedness
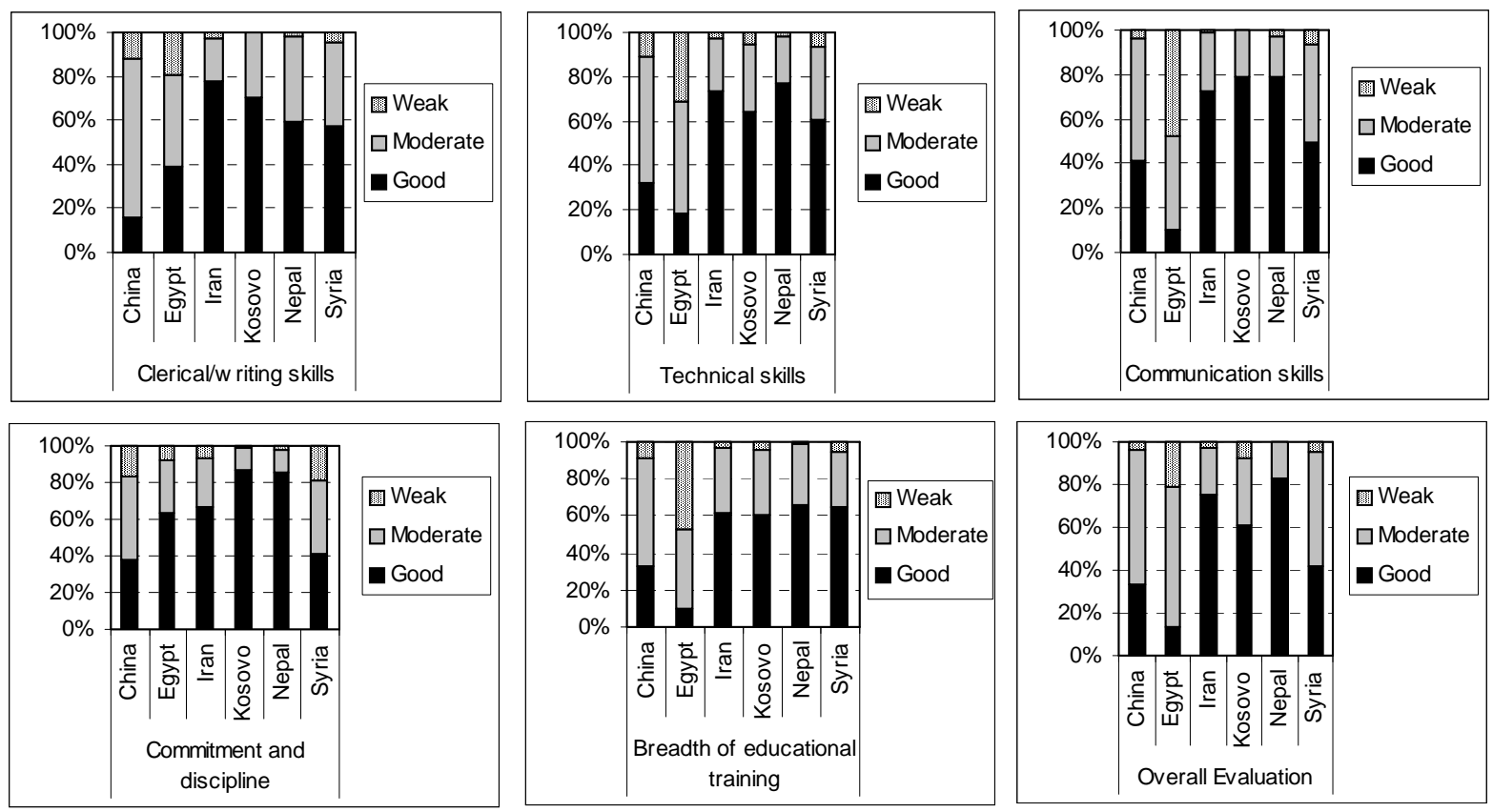


\subsection{Summary}

SWTSs are an essential tool for gaining a better understanding of the problems of labour market entrants. The survey can serve as a tool allowing countries to capture both quantitative and qualitative variables such as young people's education and training experience, their perceptions and aspirations in terms of employment, their life goals and values, the job search process, the family's influence on the choice of occupation, barriers to and supports for entry into the labour market, the preference for wage employment or self-employment or for public or private sector employment, attitudes of employers towards hiring young workers, current employment/working conditions, control over resources, job satisfaction, marriage and family responsibilities and gender differentials. The survey focuses on the transition and the variables behind the relative ease or difficulty of the transition in order to gauge where and how countries can proceed towards improving the process of matching the supply and demand for young labour. The objective of the surveys is to arm policy makers, employers' organizations, trade unions and youth themselves with timely information on specific youth labour market challenges so that appropriate policies and programmes can be designed in response to measurable needs. 


\section{Annex 1. Key regional labour market indicators for youth and issues for consideration}

The following tables present the most current labour market indicators for youth and offer a general assessment of the most pressing issues in each region. ${ }^{61}$ These tables can be used as a starting point for policy makers and international agencies as indication of the true challenges that need to be focused on regarding young people. The variations of indicator results and issues for consideration presented in each regional table are a reminder that it is better to discuss youth labour market trends on the regional level rather than the global level.

\section{Developed Economies and European Union}

\begin{tabular}{|c|c|}
\hline \multicolumn{2}{|l|}{ Current labour market indicators } \\
\hline $\begin{array}{l}\text { Labour market indicators } \\
\text { - } \text { Youth labour force participation rate: } 51.8 \% \\
\text { - } \text { Youth employment-to-population ratio: } 45.0 \\
\text { - } \quad \text { Youth unemployment rate: } 13.1 \% \\
\text { - } \text { One in } 4 \text { of the total employed are young } \\
\text { - } \quad \text { Ratio of youth to adult unemployment rate: } 2.3 \\
\text { - } \text { Change in youth inactivity rate } 1995-2005: 3.7 \% \\
\text { - } \text { Highest share of employment in Services }(71 \%) \text {; share of } \\
\text { - } \text { employment in Agriculture, } 4 \% \\
\text { - } \text { - } \text { participation rates: }-4.4 \text { percentage points } \\
-1.0 \text { percentagen female and male youth unemployment rates: }\end{array}$ & $\begin{array}{l}\text { Demographics } \\
\text { - Share of youth in working-age pop: } 15.7 \% \\
\text { - Children and youth cohort is shrinking; less than a third of } \\
\text { the population under the age of } 25 \text { by } 2025 \\
\text { Other } \\
\text { - Average GDP growth rate } 2000-05: 2.4 \\
\text { - Educational enrolment at secondary and tertiary levels: } \\
\text { high }\end{array}$ \\
\hline \multicolumn{2}{|l|}{ Some issues for consideration } \\
\hline \multicolumn{2}{|c|}{$\begin{array}{l}\text { - Job quality - equal pay for work of equal value, contracts, hours of work } \\
\text { - Balancing flexibility with security } \\
\text { - Gender wage gaps } \\
\text { - Declining employment content of growth }\end{array}$} \\
\hline
\end{tabular}

Central and Eastern Europe (non-EU) and CIS

\begin{tabular}{|c|c|}
\hline \multicolumn{2}{|l|}{ Current labour market indicators } \\
\hline $\begin{array}{l}\text { Labour market indicators } \\
\text { - } \text { Youth labour force participation rate: } 41.8 \% \\
\text { - } \text { Youth employment-to-population ratio: } 33.5 \\
\text { - } \text { Youth unemployment rate: } 19.9 \% \\
\text { - } \text { One in } 3 \text { of the total unemployed are young } \\
\text { - } \text { Ratio of youth to adult unemployment rate: } 2.6 \\
\text { - } \text { Change in youth inactivity rate } 1995-2005: 10.2 \% \\
\text { - } \text { Highest share of employment in Services }(50 \%) \text {, share of } \\
\text { employment in Agriculture, } 23 \% \\
\text { - Gap between female and male youth labour force } \\
\text { participation rates: }-13.4 \text { percentage points } \\
\text { Gap between female and male youth unemployment rates: - } \\
0.8 \text { percentage point }\end{array}$ & $\begin{array}{l}\text { Demographics } \\
\text { - Share of youth in working-age pop: } 22.1 \% \\
\text { - Children and youth cohort is shrinking; only a third of the } \\
\text { population under the age of } 25 \text { by } 2025 \\
\text { Other } \\
\text { - } \\
\text { - } \\
\text { - Yvouth US } \$ 1 \text { a day working poverty rate: } 2.9 \% \\
\text { Educational enrolment at secondary and tertiary levels: } \\
\text { medium to weak }\end{array}$ \\
\hline Some issues for consideration & \\
\hline
\end{tabular}

\footnotetext{
${ }^{61}$ Unless otherwise stated data are for 2005. It is important to bear in mind when reviewing this table that the regional assessments mask a great deal of regional variation and readers should be wary of assuming a particularly country "fits" perfectly all of the characterizations defined. For example, the overall youth unemployment rate of South Asia is relatively low at 10 per cent; however, this masks the wide variation between countries, where India, for example, had a youth unemployment rate of 10.5 per cent in 2004, while the rate was 28.9 per cent in Sri Lanka. The issues for consideration identified are general and are not meant to be all-inclusive.
} 
- Managing external migration - brain drain

- Encouraging investment and job creation

- Balancing flexibility with security

- Childcare facilities necessary to allow women to work Labour market indicators

- Youth labour force participation rate: $67.3 \%$

- Youth employment-to-population ratio: 62.1

- Youth unemployment rate: $7.8 \%$

- Two in 5 of the total unemployed are young

- Ratio of youth to adult unemployment rate: 2.8

- Change in youth inactivity rate 1995-2005: $31.5 \%$

- Highest share of employment in Agriculture (58\%), share of employment in Services, 19\%

- Gap between female and male youth labour force participation rates: 2.1 percentage points

- Gap between female and male youth unemployment rates: -2.8 percentage point

Some issues for consideration

- Job quality - social protection, social dialogue, hours of work

- Inequity in rural and urban development

- Improving the school-to-work transition

- Managing external and internal (rural to urban) migration

- Job security in small and medium enterprises

South East Asia and the Pacific

\begin{tabular}{|c|c|}
\hline & \\
\hline $\begin{array}{l}\text { Labour market indicators } \\
\text { - Youth labour force participation rate: } 56.5 \% \\
\text { - } \text { Youth employment-to-population ratio: } 47.5 \\
\text { - } \quad \text { Youth unemployment rate: } 15.8 \% \\
\text { - Three in } 5 \text { of the total unemployed are young } \\
\text { - } \text { Ratio of youth to adult unemployment rate: } 5.1 \\
\text { - Change in youth inactivity rate } 1995-2005: 4.0 \% \\
\text { - Highest share of employment in Agriculture ( } 44 \%) \text {, share of } \\
\text { - } \text { employment in Services, } 35 \% \\
\text { - } \text { participation rates: }-15.7 \text { percentage points } \\
0.5 \text { percentage point }\end{array}$ & $\begin{array}{l}\text { Demographics } \\
\text { - Share of youth in working-age pop: } 27.5 \% \\
\text { - Youthful population; by 2025, } 42 \% \text { of the population will } \\
\text { still be under the age of } 25 \\
\text { Other } \\
\text { - } \\
\text { - } \\
\text { - Yverage GDP growth rate } 2000-05: 5.2 \\
\text { - Educational enrolment at secondary and tertiary levels: } \\
\text { medium to low }\end{array}$ \\
\hline Somo iccups for concidoration & \\
\hline $\begin{array}{l}\text { - Youthful population adds pressure for job growth to accomm } \\
\text { - } \text { Invisible underemployment base on skills mismatch, namely } \\
\text { - } \text { - Ime trained lawyer driving a taxi) } \\
\text { - Improving education enrolment rates } \\
\text { - Encouraging investment and job creation } \\
\text { - Managing external and internal (rural to urban) migration } \\
\text { - Youth reluctant to enter the private sector } \\
\text { - Formal sector growth }\end{array}$ & $\begin{array}{l}\text { youth taking jobs that do not make use of their skills (example } \\
\text { ent within the rural non-farm sector }\end{array}$ \\
\hline
\end{tabular}

\section{Demographics}

- Share of youth in working-age pop: $20.9 \%$

- Children and youth cohort is shrinking; only a third of the population under the age of 25 by 2025 Other

- Average GDP growth rate 2000-05: 8.5

- Youth US $\$ 1$ a day working poverty rate: $13.4 \%$

- Educational enrolment at secondary and tertiary levels: high 


\section{South Asia}

Current labour market indicators

Labour market indicators

- Youth labour force participation rate: $47.2 \%$

- Youth employment-to-population ratio: 42.5

- Youth unemployment rate: $10.0 \%$

- One in 2 of the total unemployed are youth

- Ratio of youth to adult unemployment rate: 2.8

- Change in youth inactivity rate 1995-2005: 6.8\%

- Highest share of employment in Agriculture (62\%), share of employment in Services, 24\%

- Gap between female and male youth labour force participation rates: -35.1 percentage points

- Gap between female and male youth unemployment rates: 0.7 percentage point Some issues for consideration

- Graduate unemployment

- Invisible underemployment based on skills mismatch, namely youth taking jobs that do not make use of their skills (example: the trained lawyer driving a taxi)

- Barriers to labour market entry high for young women

- Youthful population adds pressure for job growth to accommodate labour market entrants

- Improving job quality in the agricultural sector and development within the rural non-farm sector

- Managing external and internal (rural to urban) migration

- Encouraging investment and job creation

- Youth reluctant to enter the private sector

- High poverty

- Formal sector growth

- Civil conflicts

- Improving education enrolment rates
- Share of youth in working-age pop: $29.3 \%$

- Very youthful population; by 2025 , almost half of the Other

- Average GDP growth rate 2000-05: 6.0

- Youth US\$1 a day working poverty rate: $37 \%$

- Educational enrolment at secondary and tertiary levels: medium to low

\begin{tabular}{|c|c|}
\hline \multicolumn{2}{|l|}{ Current labour market indicators } \\
\hline 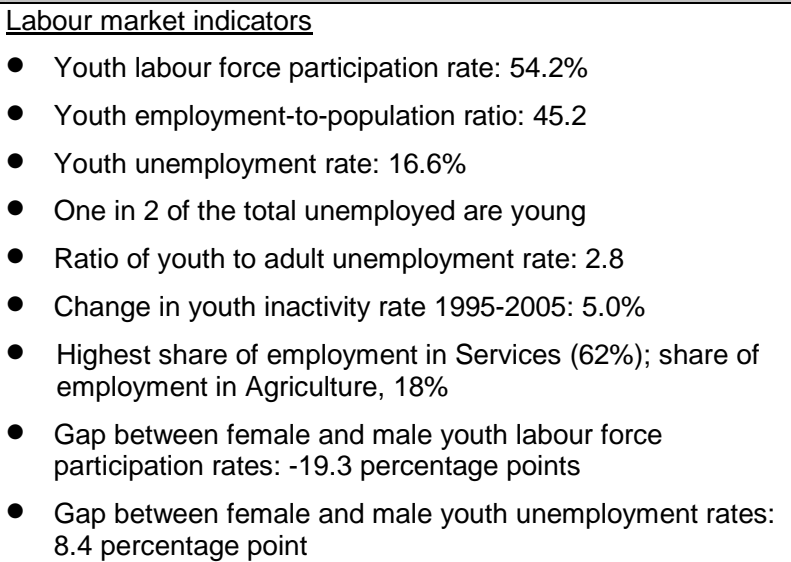 & $\begin{array}{l}\text { Demographics } \\
\text { - Share of youth in working-age pop: } 26.9 \% \\
\text { - Youthful population; by } 2025,39 \% \text { of the population will } \\
\text { still be under the age of } 25 \\
\text { Other } \\
\text { - } \\
\text { - } \\
\text { - Yverage GDP growth rate } 2000-05: 2.8 \\
\text { - Educational enrolment at secondary and tertiary levels: } \\
\text { medium }\end{array}$ \\
\hline \multicolumn{2}{|l|}{ Some issues for consideration } \\
\hline $\begin{array}{l}\text { - Barriers to labour market entry high for young women } \\
\text { - Improving education enrolment rates and education system } \\
\text { - } \text { Youthful population adds pressure for job growth to accomm } \\
\text { - Encouraging investment and job creation } \\
\text { - } \text { Formal sector growth } \\
\text { - Improving education enrolment rates } \\
\text { - Job quality }\end{array}$ & date labour market entrants \\
\hline
\end{tabular}


Middle East and North Africa

\begin{tabular}{|c|c|}
\hline \multicolumn{2}{|l|}{ Current labour market indicators } \\
\hline $\begin{array}{l}\text { Labour market indicators } \\
\text { - Youth labour force participation rate: } 40.0 \% \\
\text { - } \quad \text { Youth employment-to-population ratio: } 29.7 \\
\text { - } \text { Youth unemployment rate: } 25.7 \% \\
\text { - } \text { One in } 2 \text { of the total unemployed are young } \\
\text { - } \text { Change in youth inactivity rate } 1995-2005: 0.1 \% \\
\text { - } \text { Highest share of emp in Services ( } 47 \%) \text {; share of emp in } \\
\text { - } \text { Agriculture, } 26 \% \\
\text { - } \text { participation rates: }-29.2 \text { percentage points } \\
\text { - Gap between female and male youth unemployment rates: } \\
8.0 \text { percentage point }\end{array}$ & $\begin{array}{l}\text { Demographics } \\
\text { - Share of youth in working-age pop: } 32.6 \% \\
\text { - Youthful population; by } 2025,45 \% \text { of the population will } \\
\text { still be under the age of } 25 \\
\text { Other } \\
\text { - } \\
\text { - } \\
\text { - Yverage GDP growth rate } 2000-05: 4.7 \\
\text { - Educational enrolment at secondary and tertiary levels: } \\
\text { medium to high }\end{array}$ \\
\hline \multicolumn{2}{|l|}{ Some issues for consideration } \\
\hline $\begin{array}{l}\text { - Barriers to labour market entry high for young women } \\
\text { - Graduate unemployment } \\
\text { - Job quality } \\
\text { - Managing external and internal migration } \\
\text { - Youth reluctant to join the private sector } \\
\text { - Investment and job creation } \\
\text { - Youthful population adds pressure for job growth to accomr } \\
\text { - Informal job search / hiring networks } \\
\text { - Civil conflicts }\end{array}$ & odate labour market entrants \\
\hline
\end{tabular}

\section{Sub-Saharan Africa}

Current labour market indicators Labour market indicators

- Youth labour force participation rate: $65.5 \%$

- Youth employment-to-population ratio: 53.7

- Youth unemployment rate: $18.1 \%$

- Three in 5 of the total unemployed are young

- Ratio of youth to adult unemployment rate: 3.0

- Change in youth inactivity rate 1995-2005: 8.3\%

- Highest share of employment in Agriculture (65\%), share of employment in Services, $27 \%$

- Gap between female and male youth labour force participation rates: -16.4 percentage points

- Gap between female and male youth unemployment rates: 2.5 percentage points Some issues for consideration

- Invisible underemployment based on skills mismatch likely to be very high as well, namely youth taking jobs that do not make use of their skills (example: the trained lawyer driving a taxi)

- High poverty

- Youthful population adds pressure for job growth to accommodate labour market entrants

- Civil conflicts, child soldiers

- Improving education enrolment rates and education system

- Nutrition and disease, including HIV-AIDS

- Improving job quality in the agricultural sector and development within the rural non-farm sector

- Encouraging investment and job creation

- Managing external and internal (rural to urban) migration

- Youth reluctant to enter the private sector

- Formal sector growth

- Improving infrastructure 
Annex 2. Global employment trends - regional groupings

\begin{tabular}{|c|c|c|c|c|c|c|}
\hline $\begin{array}{l}\text { Developed } \\
\text { Economies and } \\
\text { European Union } \\
\text { European Union } \\
\text { Austria } \\
\text { Belgium } \\
\text { Cyprus } \\
\text { Czech Republic } \\
\text { Denmark } \\
\text { Estonia } \\
\text { Finland } \\
\text { France } \\
\text { Germany } \\
\text { Greece } \\
\text { Hungary } \\
\text { Ireland } \\
\text { Italy } \\
\text { Latvia } \\
\text { Lithuania } \\
\text { Luxembourg } \\
\text { Malta } \\
\text { Netherlands } \\
\text { Poland } \\
\text { Portugal } \\
\text { Slovakia } \\
\text { Slovenia } \\
\text { Spain } \\
\text { Sweden } \\
\text { United Kingdom } \\
\text { North America } \\
\text { Canada } \\
\text { United States } \\
\text { Other Developed } \\
\text { Economies } \\
\text { Australia } \\
\text { Gibraltar } \\
\text { Greenland } \\
\text { Isle of Man } \\
\text { Israel } \\
\text { Japan } \\
\text { New Zealand }\end{array}$ & $\begin{array}{l}\text { San Marino } \\
\text { St. Pierre and } \\
\text { Miquelon } \\
\text { Western Europe (non- } \\
\text { EU) } \\
\text { Andora } \\
\text { Iceland } \\
\text { Liechtenstein } \\
\text { Monaco } \\
\text { Norway } \\
\text { Switzerland } \\
\text { Central and Eastern } \\
\text { Europe (non-EU) and } \\
\text { CIS } \\
\text { Central and Eastern } \\
\text { Europe } \\
\text { Albania } \\
\text { Bosnia and } \\
\text { Herzegovina } \\
\text { Bulgaria } \\
\text { Croatia } \\
\text { Romania } \\
\text { The former Yugoslav } \\
\text { Republic of } \\
\text { Macedonia } \\
\text { Serbia and } \\
\text { Montenegro } \\
\text { Turkey } \\
\text { Commonwealth of } \\
\text { Independent States } \\
\text { Armenia } \\
\text { Azerbaijan } \\
\text { Belarus } \\
\text { Georgia } \\
\text { Kazakhstan } \\
\text { Kyrgyzstan } \\
\text { Republic of Moldova } \\
\text { Russian Federation } \\
\text { Tajikistan } \\
\text { Turkmenistan }\end{array}$ & $\begin{array}{l}\text { Ukraine } \\
\text { Uzbekistan } \\
\text { East Asia } \\
\text { China } \\
\text { Hong Kong, China } \\
\text { Korea, Democratic } \\
\text { People's Republic of } \\
\text { Korea, Republic of } \\
\text { Macau, China } \\
\text { Mongolia } \\
\text { Taiwan, China } \\
\text { South East Asia and } \\
\text { the Pacific } \\
\text { South East Asia } \\
\text { Brunei Darussalam } \\
\text { Cambodia } \\
\text { East Timor } \\
\text { Indonesia } \\
\text { Lao People's } \\
\text { Democratic } \\
\text { Republic } \\
\text { Malaysia } \\
\text { Myanmar } \\
\text { Philippines } \\
\text { Singapore } \\
\text { Thailand } \\
\text { Viet Nam } \\
\text { Pacific Islands } \\
\text { American Samoa } \\
\text { Cook Islands } \\
\text { Fiji } \\
\text { French Polynesia } \\
\text { Guam } \\
\text { Kiribati } \\
\text { Marshall Islands } \\
\text { Nauru } \\
\text { New Caledonia } \\
\text { Niue } \\
\text { Papua New Guinea }\end{array}$ & $\begin{array}{l}\text { Northern Mariana } \\
\text { Islands } \\
\text { Samoa } \\
\text { Solomon Islands } \\
\text { Tokelau } \\
\text { Tonga } \\
\text { Tuvalu } \\
\text { Vanuatu } \\
\text { Wallis and Futuna Islands } \\
\text { South Asia } \\
\text { Afghanistan } \\
\text { Bangladesh } \\
\text { Bhutan } \\
\text { India } \\
\text { Maldives } \\
\text { Nepal } \\
\text { Pakistan } \\
\text { Sri Lanka } \\
\text { Latin America and the } \\
\text { Caribbean } \\
\text { Caribbean } \\
\text { Anguilla } \\
\text { Antigua and Barbuda } \\
\text { Aruba } \\
\text { Bahamas } \\
\text { Barbados } \\
\text { Bermuda } \\
\text { British Virgin Islands } \\
\text { Cayman Islands } \\
\text { Cuba } \\
\text { Dominica } \\
\text { Dominican Republic } \\
\text { Grenada } \\
\text { Guadeloupe } \\
\text { Guyana } \\
\text { Haiti } \\
\text { Jamaica } \\
\text { Martinique } \\
\text { Montserrat } \\
\text { Netherlands Antilles }\end{array}$ & $\begin{array}{l}\text { Puerto Rico } \\
\text { Saint Kitts and Nevis } \\
\text { Saint Lucia } \\
\text { Saint Vincent and the } \\
\text { Grenadines } \\
\text { Suriname } \\
\text { Trinidad and Tobago } \\
\text { Turks and Caicos } \\
\text { Islands } \\
\text { United States Virgin } \\
\text { Islands } \\
\text { Central America } \\
\text { Belize } \\
\text { Costa Rica } \\
\text { El Salvador } \\
\text { Guatemala } \\
\text { Honduras } \\
\text { Mexico } \\
\text { Nicaragua } \\
\text { Panama } \\
\text { South America } \\
\text { Argentina } \\
\text { Bolivia } \\
\text { Brazil } \\
\text { Chile } \\
\text { Colombia } \\
\text { Ecuador } \\
\text { Falkland Islands } \\
\text { (Malvinas) } \\
\text { French Guiana } \\
\text { Paraguay } \\
\text { Peru } \\
\text { Uruguay } \\
\text { Venezuela } \\
\text { Sub-Saharan Africa } \\
\text { Eastern Africa } \\
\text { Burundi } \\
\text { Comoros } \\
\text { Eritrea } \\
\text { Ethiopia }\end{array}$ & $\begin{array}{l}\text { Kenya } \\
\text { Madagascar } \\
\text { Malawi } \\
\text { Mauritius } \\
\text { Mozambique } \\
\text { Réunion } \\
\text { Rwanda } \\
\text { Seychelles } \\
\text { Tanzania, United } \\
\text { Republic of } \\
\text { Uganda } \\
\text { Zambia } \\
\text { Zanzibar } \\
\text { Zimbabwe } \\
\text { Middle Africa } \\
\text { Angola } \\
\text { Cameroon } \\
\text { Central African } \\
\text { Republic } \\
\text { Chad } \\
\text { Congo } \\
\text { Congo, Democratic } \\
\text { Republic of } \\
\text { Equatorial Guinea } \\
\text { Gabon } \\
\text { Sao Tome and } \\
\text { Principe } \\
\text { Southern Africa } \\
\text { Botswana } \\
\text { Lesotho } \\
\text { Namibia } \\
\text { South Africa } \\
\text { Swaziland } \\
\text { Western Africa } \\
\text { Benin } \\
\text { Burkina Faso } \\
\text { Cape Verde } \\
\text { Côte d'lvoire } \\
\text { Gambia } \\
\text { Ghana } \\
\text { Guinea } \\
\end{array}$ & $\begin{array}{l}\text { Guinea-Bissau } \\
\text { Liberia } \\
\text { Mali } \\
\text { Mauritania } \\
\text { Niger } \\
\text { Nigeria } \\
\text { Senegal } \\
\text { Sierra Leone } \\
\text { St. Helena } \\
\text { Togo } \\
\text { Middle East and } \\
\text { North Africa } \\
\text { Middlle East } \\
\text { Bahrain } \\
\text { Djibouti } \\
\text { Iran, Islamic Republic } \\
\text { of } \\
\text { Iraq } \\
\text { Jordan } \\
\text { Kuwait } \\
\text { Lebanon } \\
\text { Oman } \\
\text { Qatar } \\
\text { Saudi Arabia } \\
\text { Somalia } \\
\text { Syrian Arab Republic } \\
\text { United Arab Emirates } \\
\text { West Bank and Gaza } \\
\text { Strip } \\
\text { Yemen } \\
\text { North Africa } \\
\text { Algeria } \\
\text { Egypt } \\
\text { Libyan Arab } \\
\text { Jamahiriya } \\
\text { Morocco } \\
\text { Sudan } \\
\text { Tunisia }\end{array}$ \\
\hline
\end{tabular}




\section{Annex 3. Glossary of labour market terms}

Labour market statistics and the indicators generated from the statistics can cause a great deal of confusion and, therefore, misinterpretation among users. The following glossary of labour market concepts should serve to clarify much of the terminology used in this report:

Currently active population: the best known measure of the economically active population, also known as the "labour force" (see definition below).

Discouraged worker: a person who is without work and available for work but did not seek work (and therefore could not be classified as "unemployed") because s/he felt that no work would be available to her/him. According to the standard classification system, the discouraged worker is counted among the inactive, although many analysts would like to see the number of discouraged workers added to the unemployed to give a broader measure of the unutilized supply of labour. "Discouraged" implies a sense of "giving up", meaning the discouraged worker has simply given up any hope of finding work for reasons such as s/he feels s/he lacks the proper qualifications, s/he does not know where or how to look for work, or s/he feels that no suitable work is available. The discouraged worker, therefore, could be said to be "involuntarily" inactive.

Economically active population: all persons who supplied labour for the production of goods and services in a specified reference period; in other words, all persons who undertook economic activity (also known as "market activities"), as defined by the 1993 UN System of National Accounts (SNA), ${ }^{1}$ during the measured time frame.

Employed: a person who performed some work - for at least one hour during the specified reference period for wage or salary (paid employment) or for profit or family gain (self-employment). A person is also considered employed if $\mathrm{s} / \mathrm{he}$ has a job but was temporarily not at work during the reference period.

Employment: a measure of the total number of employed persons.

Employment-to-population ratio: the number of employed persons as a percentage of the working-age population. This indicator measures the proportion of the population who could be working (the working-age population) who are working, and as such provides some information on the efficacy of the economy to create jobs.

Inactive: a person who is neither employed nor unemployed, or, equivalently, is not in the labour force.

Inactivity rate: the sum of all inactive persons as a percentage of the working-age population. As an inverse to the labour force participation rate, the inactivity rate serves as a measure of the relative size of the population who do not supply labour for the production of goods and services.

Job: a paid position of regular employment. According to the standard definition, therefore, only the wage and salaried workers could have a "job". Common usage, however, has extended the concept to encompass any work-related task, which means that any employed person, whether a paid employee or self-employed, could qualify as "with a job".

Labour force: ${ }^{2}$ the sum of all persons above a specified age (the nationally defined "working age") who were either employed or unemployed over a specified short reference period; the labour force is the best known measure of the economically active population, and is also known as the "currently active population". The labour force (employment + unemployment $)+$ the economically inactive population $=$ total working-age population of a country.

Labour force participation rate: the sum of persons in the labour force as a percentage of the working-age population. The indicator serves as a measure of the relative size of the labour supply available for the production of goods and services.

Labour market: the virtual (non-tangible) arena where workers compete for jobs and employers compete for workers. Analysts use labour market information, including statistics such as the employment-to-population ratio, the unemployment rate, etc., to make assessments of how well the labour market functions and how and/or why the supply of labour and the demand for labour do not meet at perfect equilibrium. 
Unemployed: a person who, during the specified short reference period, was (a) without work, (b) currently available for work, and (c) seeking work. A person is also considered unemployed if s/he is not currently working but has made arrangements to take up paid or self-employment at a date subsequent to the reference period.

Unemployment: a measure of the total number of unemployed persons.

Unemployment rate: unemployment as a percentage of the total labour force (employment + unemployment). The indicator is widely used as a measure of unutilized labour supply.

Work: as a verb, a general term meaning to engage in "economic activity", or, equivalently, to supply labour as input in the production of goods and services; as a noun, "work" has come to be used interchangeably with "job" and "employment" - for example, a person who supplies labour might say s/he "has work" or "has a job" or even "has employment".

Working: an informal synonym for "employed".

${ }^{1}$ See website http://unstats.un.org/unsd/sna1993/introduction.asp for additional information on the SNA and the guidelines for determining economic activity.

2 The international standard that serves to guide statisticians in the definition of the economically active population and its categories is the Resolution concerning statistics of the economically active population, employment, unemployment and underemployment, adopted by the 13th International Conference of Labour Statisticians, October 1982; www.ilo.org/public/english/bureau/stat/download/res/ecacpop.pdf. 


\section{References}

Chacaltana, J. 2006: Empleo para los jóvenes (CEPAL, Santiago); www.cedepperu.org/empleos_jovenes.pdf.

China Labour Bulletin. 2005: “China’s unlimited labour supply” (Hong Kong), 25 October; www.chinalabour.org.hk/public/contents/news?revision\%5fid=18032\&item\%5fid=18031.

Crespi Tarantino, G. 2004: "Imputation, estimation and prediction using the Key Indicators of the Labour Market (KILM) data set”, Employment Strategy Paper No. 2004/16 (ILO, Geneva); www.ilo.org/public/english/employment/strat/download/esp16.pdf.

Curtain, R. 2004: Youth in extreme poverty: Dimensions and policy implications with particular focus on South East Asia (National Institute for Governance, Melbourne); www.un.org/esa/socdev/unyin/workshops/curtain.pdf.

-. 2002: Youth in extreme poverty: Dimensions and country responses, Expert Meeting on Global Priorities for Youth, Helsinki, 6-8 October, 2002; www.curtainconsulting.net.au/download_controlled/Youth\%20\&\%20Development/Rcurtain\%20youth\%20in\%20po verty\%20\%2021\%20Sept.pdf.-.

Department of Census and Statistics. 2002a: "Headcount index and population below poverty line by DS Division - Sri Lanka, 2002”; www.statistics.gov.lk/poverty/small\%20area\%20reportNEW.pdf.

—. 2002b: “Annual bulletin of labour force - 2002" (Colombo); www.statistics.gov.lk/samplesurvey/bullet2002.pdf.

Diez de Medina, R. 2001: Jóvenes y empleo en los noventa (CINTERFOR, Montevideo); www.cinterfor.org.uy/public/spanish/region/ampro/cinterfor/publ/diez/index.htm.

ECA. 2005: Economic report on Africa 2005: Meeting the challenges of unemployment and poverty in Africa (Addis Ababa).

Elder, S. and Schmidt, D. 2004: “Global employment trends for women”, Employment Strategy Paper No. 2004/8 (ILO, Geneva); www.ilo.org/trends.

EUROSTAT. 2005: "Labour market latest trends: 1st quarter 2005 data”, in Statistics in focus (Luxembourg, European Communities), 16/2005; http://epp.eurostat.cec.eu.int/cache/ITY_OFFPUB/KS-NK-05016/EN/KS-NK-05-016-EN.PDF.

Eyraud, F. and Saget, C. 2005: The fundamentals of minimum wage fixing (ILO, Geneva).

Godfrey, M. 2003: "Youth employment policy in developing and transition countries: Prevention as well as cure”, World Bank Social Protection Discussion Paper No. 0320 (Washington, DC), October.

Gregg, P. and Tominey, E. 2004: "The wage scar from youth unemployment" (The Centre for Market and Public Organisation, Department of Economics, University of Bristol).

Guarcello, L., Manacorda, M, Rosati, F., et al., 2005: "School-to-work transitions in sub-Saharan Africa: An overview”, UCW Working Paper (Understanding Children's Work Project, Florence), 7 November; www.ucw-project.org/pdf/publications/youthSSA.pdf.

ILO. 2006a: Labour and social trends in Asia and the Pacific 2006 (Bangkok); www.ilo.org/public/english/region/asro/bangkok/14arm/download/labour.pdf.

—. 2006b: "Russia needs migrant workers to support economic growth", ILO Feature services article (July); www.ilo.org/public/english/bureau/inf/features/06/migrant_russia.htm.

—. 2006c: Global employment trends brief (Geneva); www.ilo.org/public/english/employment/strat/download/getb06en.pdf.

—. 2005a: Key indicators of the labour market, fourth edition, CD-ROM (Geneva); www.ilo.org/kilm.

—. 2005b: World employment report 2004-05: Employment, productivity and poverty reduction (Geneva).

—. 2004a: Global employment trends for youth (Geneva); www.ilo.org/public/english/employment/strat/global04.htm.

-. 2004b: "Towards a fair deal for migrant workers in the global economy", Background report of the International Labour Conference, 92nd Session (Geneva), June; www.ilo.org/public/english/protection/migrant/download/exsuvie.pdf. 
—. 2003: "Working out of poverty", Report of the Director-General, International Labour Conference, 91st Session (Geneva), June; www.ilo.org/public/english/standards/relm/ilc/ilc91/pdf/rep-i-a.pdf.

- 1990: Surveys of economically active population, employment, unemployment and underemployment: An ILO manual on concepts and methods (Geneva).

Johnson, J. and McGregor, R. 2006: “Are India and China up to the job?”, in The Financial Times (London), 19 July.

Kapsos, S. 2006 (forthcoming): "World and regional trends in labour force participation: Methodologies and key results", Employment Strategy Paper No. 2006/2 (ILO, Geneva).

- 2004: "Estimating growth requirements for reducing working poverty: Can the world halve working poverty by 2015?", Employment Strategy Paper No. 2004/14 (ILO, Geneva);

www.ilo.org/public/english/employment/strat/download/esp14.pdf.

Kolev, A. and Saget, C. 2005: "Understanding youth labour market disadvantages: Evidence from south-east Europe", in International Labour Review (ILO, Geneva), Vol. 144, No. 2.

ReliefWeb. 2004: "Youth unemployment and regional insecurity in West Africa" (United Nations Office for West Africa), December; www.reliefweb.int/rw/RWB.NSF/db900SID/KHII6NQ3NG?OpenDocument.

Ryan, P. 2000: "The school-to-work transition: as cross-national perspective", Journal of Economic Literature (Cambridge), March; www.econ.cam.ac.uk/faculty/ryan/jelfinal.pdf.

Sen, A. 2000: "Work and rights", in International Labour Review (ILO, Geneva), Vol. 139, No. 2.

Sommers, M. 2003: "Youth, war and urban Africa: Challenges, misunderstandings and opportunities", in B. Ruble, J. Tulchin, et al., eds., Youth explosion in developing world cities (Woodrow Wilson International Center for Scholars, Washington, DC).

UN. 2006: "Fact sheet on refugee youth \& poverty reduction", UN Programme on Youth, "Tackling Poverty Together", TPT document 21; www.un.org/esa/socdev/unyin/documents/TPT21.pdf.

- 2005: World youth report 2005: Young people today, and in 2015 (Department of Economic and Social Affairs, New York); www.un.org/esa/socdev/unyin/wyr05.htm.

- 2004: World youth report 2003: The global situation of young people (Department of Economic and Social Affairs, New York); www.un.org/esa/socdev/unyin/wyr03.htm.

-. 2003: Trends in total migrant stock: The 2003 revision (Department of Economic and Social Affairs, Population Division, New York);

www.un.org/esa/population/publications/migstock/2003TrendsMigstock.pdf.

- 1992: Statistical charts and indicators on the situation of youth, 1970-1990 (New York).

UNDP. 1995: Human development report 1995 (New York).

World Bank. 2005: World development indicators, 2005 (Washington, DC). 